UNIVERSIDADE DE BRASÍLIA

FACULDADE DE MEDICINA

PROGRAMA DE PÓS-GRADUAÇÃO EM CIÊNCIAS MÉDICAS

CLAUDINER PEREIRA DE OLIVEIRA

Caracterização Citogenética Molecular das Variações no Número de Cópias (CNVs) de regiões genômicas associadas com Anomalias no Desenvolvimento do Corpo Caloso

Tese apresentada como requisito parcial para a obtenção do título de Doutor em Ciências Médicas pelo Programa de Pós-Graduação em Ciências Médicas da Universidade de Brasília.

Orientadora: Prof ${ }^{\mathrm{a}}$. Dra ${ }^{\mathrm{a}}$. Juliana Forte Mazzeu de Araujo

Brasília 
CLAUDINER PEREIRA DE OLIVEIRA

\title{
CARACTERIZAÇÃO CITOGENÉTICA MOLECULAR DAS VARIAÇÕES NO NÚMERO DE CÓPIAS (CNVS) DE REGIÕES GENÔMICAS ASSOCIADAS COM ANOMALIAS NO DESENVOLVIMENTO DO CORPO CALOSO
}

\begin{abstract}
Tese apresentada como requisito parcial para a obtenção do título de Doutor em Ciências Médicas pelo Programa de Pós-Graduação em Ciências Médicas da Universidade de Brasília.
\end{abstract}

Aprovado em 08 de julho de 2015

\section{BANCA EXAMINADORA}

\author{
Prof ${ }^{a}$ Dra Juliana Forte Mazzeu de Araújo - (Presidente) \\ Universidade de Brasília
}

\author{
Prof $^{\mathrm{a}} \mathrm{Dr}^{\mathrm{a}}$ Ana Cristina Victorino Krepischi \\ Universidade de São Paulo
}

Prof Dr Aparecido Divino da Cruz

Pontifícia Universidade Católica de Goiás

\author{
Prof ${ }^{a}$ Dr $^{\mathrm{a}}$ Kikue Terada Abe \\ Rede Sarah de Hospitais
}

Prof $^{\mathrm{a}} \mathrm{Dr}^{\mathrm{a}}$ Iruena Moraes Kessler

Universidade de Brasília 
À memória de meu querido pai, Francisco: a saudade é profunda e mantêm vivas as melhores lembranças dos momentos que compartilhamos juntos.

À memória da saudosa Prof ${ }^{a}$

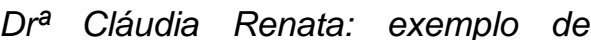
determinação e eterna fonte de inspiração.

Aos pacientes, vítimas de variações genéticas que tornaram possível este trabalho.

Dedico. 


\section{AGRADECIMENTOS}

A maior virtude de um trabalho desta natureza está no fato de que, embora nominalmente individual, seus êxitos e conquistas são fruto de um esforço coletivo e de diversas parcerias colaborativas cosntruídas ao longo da sua trajetória. Por esta razão, expresso aqui meus sinceros agradecimentos às diversas peças deste enorme quebra-cabeça científico:

- À minha ilustre orientadora Prof ${ }^{-}$Dra Juliana Mazzeu que, com sua vasta expertise no campo da Genética Médica, notoriedade intelectual e perícia em superar os desafios impostos pela atividade acadêmica em nosso país, sempre acreditou e lutou para que tornasse realidade o projeto de sonho que me apresentou e me encantou anos atrás, ajudando-me na sua compreensão e, principalmente, desafiando-me na sua construção;

- À inestimável parceria com a equipe do laboratório de Genética e Morfologia do Instituto de Biologia da UnB, chefiada pela Profa Dra Aline Pic-Taylor e pela Prof ${ }^{\mathrm{a}}$ Dr ${ }^{\mathrm{a}}$ Silviene de Oliveira, que gentilmente nos acolheu garantindo a estrutura, a qualidade, o profissionalismo e a eficiência necessária, sem os quais este trabalho não teria sido realizado;

- À colaboração fundamental de toda a equipe de Genética Médica da Faculdade de Medicina da UnB, admiravelmente conduzida pela Prof ${ }^{a}$ Dra Iris Ferrari, que com a excelência do Serviço de Genética Médica do HUB, contribuiu com sua experiência clínica e profissional tornando viável a execução deste trabalho;

- Ao suporte incondicional e essencial da equipe de médicos, biólogos e profissionais da saúde do Núcleo de Genética do Hospital de Apoio de Brasília, incansavelmente conduzidos pela Dra Maria Teresinha Cardoso, que permitiram, de formas distintas, que o trabalho construído fosse sólido diante dos desafios e encontrasse, de forma perspicaz, soluções que ultrapassam os frutos do conhecimento acadêmico;

- À Dra Cristina Medina pela grande amizade, pelo apoio fundamental, e por me fazer trilhar os surpreendentes caminhos da Genética Médica; 
- Às amigas e colaboradoras Dra Rosenelle Benício e Dra Renata Sandoval: obrigado pelas tardes de aprendizado, contribuições e disposição em discutir caso por caso;

- À equipe médica do NUGEN, em especial Drª Mara Córdoba, Dra Romina Silva, Dr ${ }^{\mathrm{a}}$ Talyta Canó, Dr ${ }^{\mathrm{a}}$ Giselle Adjuto, Dr ${ }^{\mathrm{a}}$ Maria Teresa Rosa, Dr ${ }^{\mathrm{a}}$ Graziela Machado e Dr Gerson Carvalho, que viabilizaram a realização deste trabalho.

- Às amigas de todas as horas no NUGEN: Dra Ruscaia, Bianca Fujita, Ana Carol, Edelyn, Sinara, Maisy, Maria do Socorro e Úrsula, que tornaram o andamento do trabalho muito mais divertido;

- Aos amigos e amigas: todos da turma de Sete Lagoas, Adriana, Élida, Gisele, Joses e Luciano; ao eterno amigo Prof. Aloizio Gusmão; aos compadres e comadres, Manu e Erikinha Sanchez, e Thais e Fábio Brayner; ao amigo de longa vida Wagner Coimbra; aos amigos de longa data Marcelo Salviano e David Neves; à toda equipe do CIMAN Ensino Médio; ao professor e grande amigo Guilherme Azevedo e todos da família Krav Maga; que diante da vastidão do tempo e da grandeza da vida tornaram um imenso prazer dividir as alegrias e tristezas com vocês;

- Aos amores da minha vida, Dianna e Isis Amaral: obrigado por transformaremo presente em uma aventura digna de uma saga tolkeniana, por tornarem os dias mais curtos e as noites mais longas, e por fazerem o futuro valer a pena ser vivido;

- À minha querida Família e, em especial, minha mãe Dona Zenilde, meus irmãos Claubert e Claudiana Oliveira e meu sobrinho sapeca Davi Francisco: sem o incentivo e o apoio de vocês a realidade seria outra;

- Aos membros da banca examinadora: Prof ${ }^{\mathrm{a}} \mathrm{Dr}^{\mathrm{a}}$ Ana Cristina V. Krepischi, Prof Dr Aparecido D. da Cruz, Prof ${ }^{\mathrm{a}} \mathrm{Dr}^{\mathrm{a}}$ Kikue T. Abe, Prof ${ }^{\mathrm{a}}$ Dra Iruena M. Kessler, obrigado pela paciência, pela dedicação, e pelas inestimáveis contribuições, correções, observações, puxadas de orelha, lapidações e elogios que engrandeceram de forma especial este texto;

- Ao Programa de Pós-Graduação da Faculdade de Medicina da UnB;

- Aos órgãos financiadores deste trabalho: CNPq,CAPES e FAP-DF. 
"A admiração começa onde acaba a compreensão". Charles Baudelaire 


\section{RESUMO}

Uma das malformações mais comuns do sistema nervoso é a agenesia do corpo caloso (ACC) completa ou parcial que faz parte de um grupo de malformações cerebrais complexas que, normalmente, podem resultar em atraso no desenvolvimento neuropsicomotor (ADNPM), deficiência intelectual (DI) e estar ou não associada com dismorfias e malformações congênitas múltiplas. A etiologia da ACC é heterogênea e, na maioria das vezes, envolve alterações cromossômicas que não são identificadas por citogenética convencional. A análise cromossômica por microarranjos (CMA) permitiu ampliar o alcance e a sensibilidade na detecção de deleções e duplicações submicroscópicas para a compreensão de seus papéis nos processos patogênicos e tem revelado inúmeras alterações associadas à ACC. $O$ principal objetivo deste estudo foi investigar a presença de rearranjos cromossômicos em pacientes com ACC associada à ADNPM e/ou DI e/ou malformações congênitas. Foram selecionados 54 pacientes com ACC total ou parcial, associada à ADNPM e/ou DI e sem diagnóstico de síndrome genética definida. Em todos eles foi realizada uma investigação de alterações cromossômicas submicroscópicas por meio da CMA utilizando a plataforma Affymetrix CytoScan ${ }^{\oplus} 750 k$ (Affymetrix, EUA). Dos 54 pacientes investigados, 32\% apresentaram apenas alterações submicroscópicas não descritas no DGV (Database of Genomic Variants) que foram analisadas quanto à herança e seu potencial patogênico. A CMA realizada nos genitores identificou que em $50 \%$ destes indivíduos as alterações eram de novo e em $64 \%$ dos casos as CNVs envolviam microduplicações e/ou microdeleções que não poderiam ser detectadas pelas técnicas tradicionais de cariótipo. Não foram identificadas alterações recorrentes na amostra corroborando a grande heterogeneidade genética das malformações do CC. Além disso, identificou-se também que as alterações fenotípicas provocadas por treze CNVs distintas afetam um total de treze genes e quatro regiões citogenômicas críticas para o neurodesenvolvimento que exerceriam impacto direto ou indireto nas malformações do corpo caloso. Com isso, reafirma-se a importância da CMA como instrumento inicial no diagnóstico de quadros sindrômicos em que a etiologia é desconhecida.

Palavras-chave: Agenesia do corpo caloso, CMA, SNP-array, CNVs 


\begin{abstract}
Agenesis of the corpus callosum (ACC) is among the most frequent human brain malformations and encompasses either total absence (complete ACC) or absence from birth of at least one, but not all, of the anatomically defined regions of the corpus callosum (partial ACC). It is a heterogeneous condition, for which several different genetic causes are known and it is part of complex brain malformations that typically result in developmental delays (DD ), intellectual disability (ID) and whether or not associated with dysmorphisms and multiple congenital malformations. ACC frequently involves chromosomal changes that are not identified by standard cytogenetics. Chromosomal Microarray Analysis (CMA) allowed extending the range and sensitivity in detection of submicroscopic deletions or duplications. And to investigate the presence of chromosomal rearrangements in patients with ACC linked to DD and others congenital malformations. We selected 54 patients with total or partial ACC, associated with DD and congenital malformations without knowned genetic syndrome. In all patients was carried out an investigation of submicroscopic chromosomal changes through the CMA using the Affymetrix 750k CytoScan ${ }^{\circledR}$ arrays. In cases that Copy Number Variations (CNVs) did not found in the DGV database, the parents were also investigated. CMA results demonstrate that $32 \%$ of CNVs analysed had not been described in DGV. In these cases, $50 \%$ of the CNVs were de novo and $72 \%$ were microduplications or microdeletions that could not be detected by G-banding karyotype. All CNVs found were not recurrent, consequence of remarkable genetic heterogeneity in ACC. Furthermore, CMA also demonstrated that CNVs were associated with neurodevelopmental disorders. After analysis of the results we propose thirteen new genes and four critic genomic regions identified there could be impact in corpus callosum anomalies corroborating the importance of CMA as first tier-test in cases of idiopathic syndromic ACC.
\end{abstract}

Keywords: agenesis of the corpus callosum, CMA, SNP array, copy number variation 


\section{ÍNDICE DE FIGURAS}

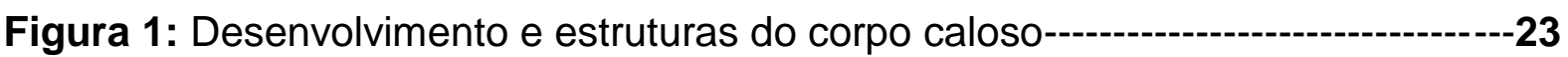

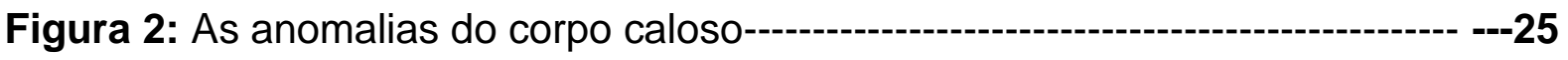

Figura 3: (a) Chip de DNA----_---45

Figura 3: (b) Cobertura genômica das sondas na plataforma Affymetrix ${ }^{\circledR}$ CytoScan ${ }^{\circledR} 750 k$ Array--

Figura 4: Protocolo da plataforma Affymetrix ${ }^{\circledR}$ CytoScan $^{\circledR}$ 750k Array-------------47

Figura 5: Etapas envolvidas na hibridação de DNA na plataforma Affymetrix ${ }^{\circledR}$ CytoScan $^{\circledR} 750 k$ Array

Figura 6: Esquema geral das etapas e dos equipamentos utilizados na CMA da plataforma Affymetrix ${ }^{\circledast}$ CytoScan $^{\circledast}$ 750k Array----_-_-

Figura 7: Vista geral do software ChAS v.3.0 (Affymetrix, EUA) pós processamento do dados da CMA.

Figura 8: Visualização de CNV pelo ChAS v. 3.0 da paciente ACC10----------------85

Figura 9: Visualização de CNV pelo ChAS v. 3.0 do paciente ACC11-----------------85

Figura 10: Visualização de CNV pelo ChAS v. 3.0 da paciente ACC20--------------87

Figura 11: Visualização de CNV pelo ChAS v. 3.0 do paciente ACC22---------------89

Figura 12: Visualização de CNV pelo ChAS v. 3.0 da paciente ACC31-------------91

Figura 13: Visualização de CNV pelo ChAS v. 3.0 do paciente ACC36---------------93

Figura 14: (a) Visualização de CNV pelo ChAS v. 3.0 do paciente ACC37------------95

Figura 14: (b) Visualização de CNV pelo ChAS v. 3.0 do paciente ACC37-----------96

Figura 14: (c) Visualização do cariograma do paciente ACC37----------------------96

Figura 15: Visualização de CNV pelo ChAS v. 3.0 da paciente ACC41-------------98

Figura 16: Visualização de CNV pelo ChAS v. 3.0 da paciente ACC42------------100

Figura 17: Visualização de CNV pelo ChAS v. 3.0 da paciente HUB5--------------101 
Figura 18: Visualização de CNV pelo ChAS v. 3.0 da paciente ACC6--------------103

Figura 19: Visualização de CNV pelo ChAS v. 3.0 do paciente ACC12-------------105

Figura 20: Visualização de CNV pelo ChAS v. 3.0 da paciente ACC38-----------108

Figura 21: Visualização de CNV pelo ChAS v. 3.0 da paciente ACC7--------------110

Figura 22: Visualização de CNV pelo ChAS v. 3.0 da paciente ACC28-------------111

Figura 23: Visualização de CNV pelo ChAS v. 3.0 da paciente ACC33--------------112

Figura 24: Visualização de CNV pelo ChAS v. 3.0 da paciente HUB3---------------113 


\section{ÍNDICE DE TABELAS}

Tabela 1: Principais alterações fenotípicas descritas nos pacientes estudados $-59$

Tabela 2: Taxa de diagnóstico da CMA por alterações clínicas dos pacientes com ACC e outras malformações

Tabela 3: Número de pacientes correlacionando com o tipo e a origem da CNV encontrada por meio da CMA

Tabela 4: Número de pacientes em relação ao tipo, tamanho e origem das CNVs que não estão descritas no DGV encontrada por meio da CMA $-65$

Tabela 5: CNVs encontradas por meio da CMA relacionadas por cromossomo classificadas por tamanho, paciente e origem genética $-66$

Tabela 6: Descrição citogenética e interpretação quanto ao efeito fenotípico de todas as CNVs detectadas pela CMA, listadas por cromossomo, nos pacientes com anomalias do CC e outras malformações associadas $-68-69$

Tabela 7: CNVs patogênicas, detectadas por meio da CMA, em pacientes com anomalias do CC e outras malformações associadas, listando os principais genes e/ou região genômica que sugerem correlação com as malformações do CC--------73

Tabela 8: CNVs potencialmente patogênicas, detectadas por meio da CMA, em pacientes com anomalias do CC e outras malformações associadas, listando os principais genes e/ou região genômica que possivelmente estão correlacionados com as malformações do CC $-74$

Tabela 9: CNVs de significado clínico desconhecido (VOUS), detectadas por meio da CMA, em pacientes com anomalias do CC e outras malformações associadas $-74$ 


\section{LISTA DE ABREVIATURAS}

AC Anomalias Congênitas

ACC Agenesia de Corpo Caloso

AAIDD American Association on Intellectual and Developmental Disabilities

aCGH do inglês, Array Comparative Genomic Hibridization

ADNPM Atraso do Desenvolvimento Neuropsicomotor

BAC do inglês, Bacterial Artificial Chromosome

BSA do inglês, Bovine Serum Albumin

CC Corpo Caloso

CEP-FM Comitê De Ética Em Pesquisa da Faculdade de Medicina

CFTR do inglês, Cystic Fibrosis Transmembrane conductance Regulator gene

ChAS do inglês, Chromosome Analysis Suite

CMA do inglês, Chromosome Microarray Analysis

$\mathrm{CGH}$ do inglês, Comparative Genomic Hybridization

CNVs do inglês, Copy Number Variations

CRBN do inglês, Cereblon gene

DECIPHER Database of Chromosomal Imbalance and Phenotype in Humans using Ensembl Resources

DGV Database of Genomic Variants

DI Deficiência Intelectual

ADNPM Atraso do Desenvolvimento Neuropsicomotor

EDTA do inglês, Ethylenediaminetetraacetic acid

ERMARD do inglês, Endoplasmic Reticulum Membrane-Associated RNA Degradation gene

FISH do inglês, Fluorescence in situ hybridization

GAP43 do inglês, Growth Associated Protein 43 gene

HCCS do inglês, Holocytochrome C Synthase gene

hg do inglês, Human Genome

HUB/UnB Hospital Universitário da Universidade de Brasília

IBGE Instituto Brasileiro de Geografia e Estatística

INDELs inserções / deleções

ISCA The International Standards for Cytogenomic Arrays consortium

$\mathrm{Kb} \quad$ quilo base (milhares de bases) 
LCRs do inglês, Low-Copy Repeats,

LOH do inglês, Loss of Heterosygosity

$\mathrm{Mb} \quad$ Mega bases (milhões de bases)

MLPA do inglês, Multiplex Ligation-Dependent Probe Amplification

NALCN do inglês, Sodium Leak Channel, Non selective gene

NCAM2 do inglês, Neural Cell Adhesion Molecule 2 gene

NCBI National Center for Biotechnology Information

OCR do inglês, Oligo Control Reagent

OMIM Online Mendelian Inheritance in Man database

OMS Organização Mundial da Saúde

PAX6 do inglês, Paired box gene 6 gene

PCR do inglês, Polymerase Chain Reaction

RefSeq do inglês, NCBI Reference Sequence Database

RMN Ressonância magnética nuclear

SETD5 do inglês, Set Domain-containing protein 5 gene

SES/DF Secretaria de Saúde do Distrito Federal

SOX2 do inglês, SRY-box 2 gene

TCLE Termo de Consentimento livre e Esclarecido

TC Tomografia computadorizada

UCSC University of California, Santa Cruz

UPD do inglês, Uniparental Disomy

USTF Ultrassonografia transfontanela

VOUS do inglês, Variants of Unknown Significance

WHSC1 do inglês, Wolf-Hirschhorn Syndrome Candidate 1 gene

WT1 do inglês, Wilms tumor 1 gene

ZIC2 do inglês, Zinc Finger Protein of Cerebellum 2 gene 


\section{SUMÁRIO}

1.INTRODUÇÃO $-17$

1.1 A DEFICIÊNCIA INTELECTUAL$-17$

1.1.1 A prevalência e o impacto da Deficiência Intelectual$-18$

1.1.2 Diagnóstico e Etiologia da Deficiência Intelectual $-19$

1.2 O CORPO CALOSO 22

1.2.1 As Malformações do Corpo Caloso $-24$

1.2.2 As alterações genéticas envolvidas nas Malformações do CC $-28$

1.3 PLATAFORMAS DE ANÁLISE CROMOSSÔMICA POR MICROARRANJOS (CMA) $-30$

1.3.1 Oligoarrays e SNP-arrays $-33$

1.3.2 Taxa diagnóstica por meio da CMA$-35$

1.4 VARIAÇÕES DO NÚMERO DE CÓPIAS (CNVS): CLASSIFICAÇÃO E INTERPRETAÇÃO

2. JUSTIFICATIVA-

3. OBJETIVOS

3.1 OBJETIVOS GERAIS--

3.2 OBJETIVOS ESPECÍFICOS--

4.METODOLOGIA--

4.1 SELEÇÃO DE PACIENTES, CARACTERIZAÇÃO DA AMOSTRA E CONSIDERAÇÕES ÉTICAS---

4.2 ISOLAMENTO E QUANTIFICAÇÃO DO DNA GENÔMICO----------45

4.3 ANÁLISE CROMOSSÔMICA POR MICROARRANJOS (CMA)------------45

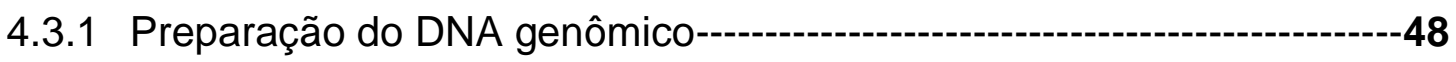

4.3.2 Digestão com Nsp I, ligação de adaptadores e amplificação-------------48 
4.3.3 Mistura dos produtos das PCRs, purificação e quantificação-

4.3.4 Fragmentação dos produtos das PCRs

4.3.5 Marcação do DNA fragmentado com biotina$-50$

4.3.6 Hibridação $-50$

4.3.7 Lavagens dos GeneChip ${ }^{\circledR}$ e marcação com fluoróforos$-51$

4.3.8 Escaneamento dos GeneChip ${ }^{\circledR}$, captação de imagens e análise no software Chromosome Analysis Suite 3.0 (Affymetrix, EUA) 52

5. RESULTADOS E DISCUSSÃO $-58$

5.1 CARACTERIZAÇÃO DA POPULAÇÃO ESTUDADA E ANÁLISE DAS ALTERAÇÕES CLÍNICAS DOS PACIENTES$-58$

5.2 ANÁLISE E CLASSIFICAÇÃO DAS CNVS ENCONTRADAS$-64$

5.3 ANÁLISE DAS CNVS RARAS$-67$

5.4 ANÁLISE DAS CNVS PATOGÊNICAS$-81$

5.4.1 Paciente ACC10 $-81$

5.4.2 Paciente ACC11 $-84$

5.4.3 Paciente ACC20 $-86$

5.4.4 Paciente ACC22 $-88$

5.4.5 Paciente ACC31 $-90$

5.4.6 Paciente ACC36$-92$

5.4.7 Paciente ACC37$-94$

5.4.8 Paciente ACC41 97

5.4.9 Paciente ACC42 $-99$

5.4.10 Paciente HUB5$-101$

5.5 CNVS POTENCIALMENTE PATOGÊNICAS $-102$

5.5.1 Paciente ACC6$-102$ 


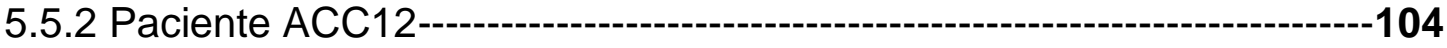

5.5.3 Paciente ACC38-

5.6 CNVS VOUS-

6. CONCLUSÕES---

7. REFERÊNCIAS--115

8.ANEXOS-139

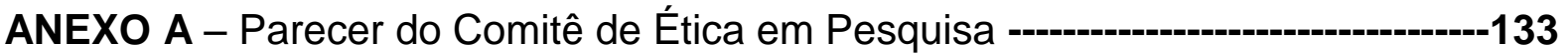

ANEXO B - Termo de Consentimento---_- 


\section{INTRODUÇÃO}

\subsection{A DEFICIÊNCIA INTELECTUAL}

A deficiência intelectual (DI), ou transtorno do desenvolvimento intelectual, é um distúrbio com início no período do desenvolvimento que inclui déficits funcionais, tanto intelectuais quanto adaptativos, nos domínios conceitual, social e prático (1). Ao longo das últimas décadas, o conceito e a caracterização das Dls modificou-se no sentido de dar ênfase às limitações significativas do funcionamento intelectual e do comportamento adaptativo abrangendo assim muitas habilidades sociais e práticas cotidianas (2). A Associação Americana de Deficiência Intelectual e de Desenvolvimento, (American Association on Intellectual and Developmental Disabilities - AAIDD) define o funcionamento intelectual como a capacidade mental geral, que envolve situações como aprendizado, raciocínio e resolução de problemas. E mais, define que o comportamento adaptativo seja um conjunto de habilidades conceituais, sociais e práticas que são aprendidas e realizadas por pessoas em suas vidas cotidianas. Tais habilidades envolvem a linguagem e alfabetização, as relações inter-pessoais/sociais, e as atividades da vida diária (3).

A DI é uma patologia cuja condição está relacionada ao neurodesenvolvimento do indivíduo surgindo antes dos dezoito anos de idade. O estudo e a compreensão da etiologia e estrutura da DI, um dos mais prevalentes distúrbios do desenvolvimento, constituem um desafio às Ciências devido a sua elevada heterogeneidade clínica e genética (4). Grande parte das Dls é classificada como sendo de causa idiopática. Ela pode se apresentar de forma isolada no indivíduo, quando o prejuízo cognitivo representa a única manifestação da patologia, sem outros sinais e sintomas presentes, sendo denominada inespecífica ou nãosindrômica. Ou pode se apresentar em associação com uma desordem com dismorfologias evidentes ou estar associada à fatores clínicos, radiológicos, metabólicos, quando vários sistemas em desenvolvimento são afetados, o que seria a DI sindrômica, que pode estar presente ou fazer parte de um quadro sindrômico (5).

Muitas síndromes genéticas conhecidas associadas à DI podem ser diagnosticadas clinicamente por meio de anamnese e exames clínicos detalhados. No entanto, a maioria dos casos não é identificada ao exame clínico sendo 
necessário realizar exames laboratoriais especializados na tentativa de se estabelecer a causa da DI, e assim compreender melhor o quadro clínico do paciente e fornecer correto aconselhamento genético às famílias (6).

\subsubsection{A prevalência e o impacto da Deficiência Intelectual}

A DI afeta 1 a 3\% da população geral nos países ocidentais (7) e sabe-se que desordens genéticas são responsáveis em mais de $50 \%$ destes casos (8). Estimativas afirmam que aproximadamente $85 \%$ dos afetados apresentam DI leve; os outros $15 \%$ dividem-se em DI moderada e grave (9).

Os custos envolvendo os cuidados ao longo da vida podem ser extremamente elevados. Por exemplo, o Centro de Controle e Prevenção de Doenças estimou em mais de um milhão de dólares o custo por indivíduo com DI ao longo da vida e 51 bilhões de dólares somente para os nascidos com DI no ano de 2000 (10). Estudo sobre o impacto econômico das chamadas "Doenças do Cérebro" no Reino Unido, em 2010, sitou a DI entre as dez desordens neurológicas mais caras, com custos superando cinco milhões de euros per capta, e entre as três que mais dependem de despesa médica direta (11).

A DI é classificada como a condição mais dispendiosa de todos os diagnósticos do Sistema de Classificação Internacional de Doenças (CID-10), superando câncer e doenças cardiovasculares (12). Estes cálculos envolvem ainda o custo da manutenção básica do indivíduo afetado (alimentação, vestuário, cuidados com saúde, educação, força de trabalho perdida) assim como o custo do trabalho de quem cuida do mesmo (9). E mais, Fineberg e colaboradores (11) destacaram que apesar dos investimentos governamentais priorizarem pesquisas no campo da saúde para as doenças de maior impacto na população e na economia, os recursos financeiros para as chamadas "Doenças do Cérebro" são baixos e os atributos de custos para a atenção à saúde são irrisórios em casos de distúrbios neurológicos.

Somente na última década do Século XX que o Brasil incluiu nos censos demográficos realizados no país, novas metodologias de coletas de dados para obter dados oficiais sobre a população com deficiência. Até então, as políticas públicas voltadas para essa população tomavam como referência a estimativa da Organização Mundial da Saúde - OMS, segundo a qual 10\% da população de um país, em tempos de paz, seria portadora de algum tipo de deficiência (13). 
No Brasil, os dados coletados pelo Instituto Brasileiro de Geografia e Estatística - IBGE, no Censo 2010, descreveram a prevalência dos diferentes tipos de deficiência e as características das pessoas que compõem esse segmento da população, onde encontrou um percentual de $8,3 \%$ da população total possui algum tipo de deficiência grave, sendo 2,6 milhões $(1,4 \%)$ de pessoas com DI. A região Centro-Oeste do país registrou mais de 170 mil pessoas com DI, das quais o Distrito Federal conta com 28.351 portadores de DI (1,1\% da população) (14).

\subsubsection{Diagnóstico e Etiologia da Deficiência Intelectual}

Atualmente, à partir dos dados clínicos obtidos na consulta e com base na experiência profissional, a maioria dos médicos consegue classificar seus pacientes quanto às formas de $\mathrm{DI}$, de acordo com o que é proposto pela $5^{\underline{a}}$ edição do Manual Diagnóstico e Estatístico de Transtornos Mentais (1). Em sua última versão, a classificação baseada em pontuações de QI é desconsiderada e desaconselhada, pois não existe mais um limiar para se estabelecer um diagnóstico além destas pontuações serem insuficientes para avaliarem o raciocínio em situações da vida real e domínio das tarefas práticas e sociais. Cabe ainda ressaltar que para o diagnóstico de DI feito antes dos cinco anos de idade utiliza-se o termo Atraso no Desenvolvimento Neuropsicomotor (ADNPM), visto que se considera a possibilidade de ser um atraso que possa ser recuperado (15).

A etiologia da DI é múltipla, altamente heterogênea, e de difícil identificação. Podem ser observadas causas genéticas ou não genéticas. Inclusive, Rauch e colaboradores em 2006 (16), estimaram que $25 \%$ dos casos de DI eram de ordem genética, $25 \%$ de origem ambiental (ou adquirida) e $50 \%$ de causa desconhecida ou multifatorial. No geral, a maior parte dos pacientes que busca aconselhamento médico não obtém um diagnóstico, especialmente naqueles casos onde o atraso é leve e não existem outros sinais associados (17).

As causas não genéticas da DI envolvem eventos pré-, peri- e pós-natais, como acidentes obstétricos que acarretem traumas cerebrais, tabagismo, alcoolismo, consumo de drogas, efeitos colaterais de medicamentos teratogênicos, doenças maternas crônicas ou gestacionais, doenças infecciosas na mãe que podem comprometer o feto (tais como meningites, sarampo, rubéola, toxoplasmose, citomegalovírus), desnutrição materna, transtornos endócrinos maternos, 
intoxicações exógenas maternas (por exemplo, por chumbo), alterações vasculares ou degenerativas encefálicas, erros inatos do metabolismo, desnutrição infantil, hipóxia ou anóxia perinatal, prematuridade e baixo peso, icterícia grave do recémnascido, desidratação grave, e carência de estimulação global que pode prejudicar o desenvolvimento intelectual normal resultando em DI (12, 18; 19; 20).

Entre as causas genéticas estão envolvidas as: desordens cromossômicas (tais como aneuploidias, rearranjos cromossômicos terminais e em regiões relacionadas com síndromes de microdeleção e microduplicação, rearranjos intersticiais, formas ligadas ao cromossomo $\mathrm{X}$ ), desordens complexas (tais como mutações em vários genes), desordens autossômicas monogênicas (tais como herança dominante ou recessiva) e que podem ser impactadas pelo imprinting genético $(4,21)$.

Os fatores genéticos são as causas mais importantes, principalmente, nos casos de DI média ou grave, onde estão presentes em mais de $60 \%$ dos casos (22). Rearranjos cromossômicos sub-teloméricos estão presentes em, pelo menos, 5\% dos casos de DI, provavelmente, devido à alta densidade de genes nestas regiões $(23,24)$.

Aproximadamente $5 \%$ dos casos da DI são causados por anomalias cromossômicas visíveis pela citogenética convencional $(7 ; 16)$ e, o crescente número de variantes genômicas associadas com a DI, muitas vezes têm levado à designação de novas síndromes clínicas $(6 ; 25 ; 26)$. Diagnósticos providos pelas análises por microarranjos ampliam em mais de $20 \%$ o número de resultados além daqueles obtidos pelo cariótipo $(27 ; 28 ; 29)$.

Dependendo da técnica utilizada para a análise, as estimativas variam entre $17 \%$ e $47,1 \%$ para os casos de DI que ocorrem em virtude da presença de variações submicroscópicas no número de cópias ou CNVs (do inglês, Copy Number Variation) (30). Xiang e colaboradores (31) em um estudo utilizando exame de Hibridação Genômica Comparativa por microarranjos ou CGH array (do inglês, Comparative Genome Microarray), com 44 mil sondas analisaram 1.499 probandos com DI alcançando uma taxa de diagnóstico entre $7 \%$ a $14 \%$, e sugeriram que o tamanho mínimo das CNVs consideradas nas investigações clínicas fosse de 300 mil bases (Kb). Em uma meta-análise de 19 estudos envolvendo 13.926 indivíduos com DI e anomalias congênitas analisadas por meio da técnica de CGH array, estimou em $10 \%$ o alcance diagnóstico (32). O consórcio internacional Clinical Genome Resource, anteriormente conhecido como The International Standards For 
Cytogenomic Arrays Consortium (ISCA), realizou uma meta-análise de 33 estudos que incluíam 21.698 pacientes testados pela Análise Cromossômica por Microarranjos ou CMA (do inglês, Chromosome Microarray Analysis) e concluiu que a técnica oferece capacidade de diagnóstico muito maior (15\% a $20 \%$ ) para os indivíduos com ADNPM e/ou DI, transtornos do espectro autista ou malformações múltiplas congênitas do que o cariótipo por banda G (3\%, excluindo Síndrome de Down e outras síndromes cromossômicas conhecidas) (29).

$O$ estudo de Hochstenbach e colaboradores (28) forneceram importantes considerações para as situações que envolviam deteç̧ão de alterações visualizadas apenas pelo cariótipo convencional. Eles concluíram que estes casos representavam $0,78 \%$ do universo de amostras estudadas e envolviam rearranjos cromossômicos balanceados que poderiam ser indetectáveis às análises pelos arrays. Incluíam rearranjos familiares $(0,48 \%$ de todos os casos), translocações reciprocas de novo e inversões $(0,23 \%)$, translocações Robertsonianas de novo $(0,04 \%)$, e triploidia $69, \mathrm{XXX}(0,03 \%)$.

Os pacientes com DI frequentemente apresentam algum tipo de malformação cerebral. Dentre elas, as anomalias no desenvolvimento do Corpo Caloso estão entre as mais frequentes e, no entanto, as diferenças na definição dos tipos de malformações calosais e suas formas variadas de detecção dificultam a realização de estudos com estimativas precisas $(33,34)$. 


\subsection{O CORPO CALOSO}

O Corpo Caloso (CC) é a maior das estruturas inter-hemisféricas da substância branca no cérebro. Ele é construído por mais de 200 milhões de axônios organizados topograficamente, que conectam os hemisférios direito e esquerdo, compreendendo aproximadamente $3 \%$ do total de fibras corticais (35). O CC é exclusivo dos mamíferos placentários e, em humanos, sua principal função é a coordenação e transferência de informações entre os dois hemisférios cerebrais auxiliando nas funções cognitivas e neurológicas. Esta comunicação interhemisférica é importante para a integração funcional das informações sensoriais, motora e óculo motora, assim como das funções cognitivas superiores envolvendo a linguagem e o raciocínio abstrato $(36,37)$.

O CC é tradicionalmente dividido em quatro segmentos distintos baseados em estudos histológicos e estruturais (38) (Figura 1). Recentes avanços nas técnicas de mapeamento cerebral possibilitaram melhor compreensão da diversidade das conexões calosas inter-hemisféricas em cada segmento, e ajudam a esclarecer o que acontece com estas conexões quando ocorre algum distúrbio no desenvolvimento embrionário ou fetal (39). 

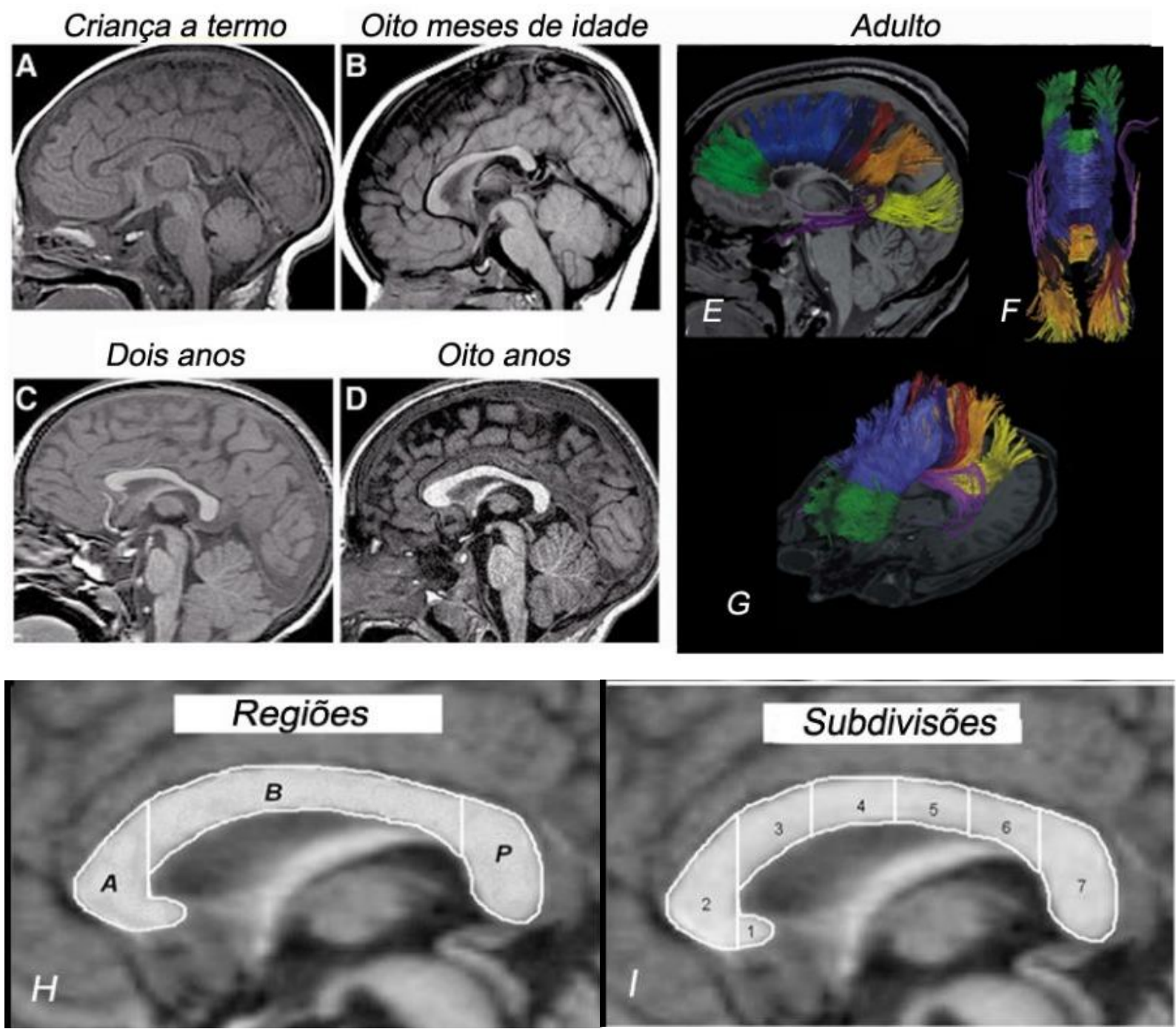

Figura 1. Corte sagital em T1 de RMN mostrando o Corpo Caloso normal em criança a termo $(\boldsymbol{A})$, criança com 8 meses de idade (B), 2 anos (C), 8 anos (D). O crescimento na seção anterior é mais pronunciado até os primeiros 10 anos de vida (compare $\mathbf{C}$ com $\mathbf{D}$ ), enquanto o crescimento posterior predomina durante a adolescência. Visualização por meio da técnica de tractrografia por RMN de indivíduo adulto em vista sagital, superior e oblíqua, respectivamente, com representação das fibras do trato calosal, compreendendo feixes projetando no lobo pré-frontal (colorido aritificialmente na cor verde), pré-motor e áreas motoras suplementares (azul claro), córtex primário motor (azul escuro), córtex primário sensorial (vermelho), lobo parietal (laranja), lobo occiptal (amarelo), e lobo temporal (violeta) (E-G). Regiões e subdivisões do CC conforme estabelecido por Witelson (1989): $A=$ Anterior, $B=$ Corpo, $P=$ Posterior; 1=rostro, 2=joelho, 3=corpo rostral, 4=corpo médio anterior, 5=corpo médio posterior, 6=istmo, 7=esplênio (H-I). (modificado e adaptado de: 40 (A-D); 41 (E-G); $42(H-I)$ ). 


\subsubsection{As Malformações do Corpo Caloso}

A Agenesia do Corpo Caloso (ACC) pode ser caracterizada pela ausência completa do CC, neste caso sendo denominada ACC completa, ou pode estar parcialmente ausente, condição simplesmente denominada ACC parcial ou Disgenesia do Corpo Caloso (DCC). Esta pode ser primária (sem a formação da porção posterior do $\mathrm{CC}$ ) ou secundária (o joelho e o corpo anterior são malformados, deixando a porção posterior do CC intacta) ou ainda representar um dos espectros das anomalias calosais, incluindo as hipoplasias, caracterizadas por um CC mais fino que o normal sem alteração na extensão anteroposterior (43) (Figura 2).

A ACC e a DCC primárias se diferenciam das DCC secundárias pelo desenvolvimento inicial normal do CC. A ACC completa é resultado de uma embriogênese defeituosa enquanto que a ACC parcial ou DCC, de uma foma geral, representa uma malformação resultante de um evento que interrompeu o desenvolvimento normal do CC em qualquer momento da gestação. Os eventos cerebrais alterados associados com a DCC são mais sutis do que os envolvidos na ACC completa. Por exemplo, a DCC da porção anterior do corpo caloso pode decorrer de uma encefalomalácia focal, enquanto que a DCC da porção posterior é, provavelmente, um fenômeno decorrente da formação incompleta do corpo caloso (44).

A ACC/DCC é uma condição amplamente heterogênea que pode ser resultado da perturbação das inúmeras etapas do desenvolvimento, desde a precoce linha média telencefálica típica até as especificações neuronais e orientações das comissuras axonais. Ela pode ser detectada como um achado isolado na RMN, ou pode estar mais comumente associado com uma desordem ampla do desenvolvimento do cérebro $(45 ; 46)$. Síndromes que estão associadas com ACC são, em geral, classificadas pelo estágio do desenvolvimento cerebral que foi afetado, seguindo estratégia similar à utilizada em outras classificações de malformações corticais. ACC pode ocorrer em associação com desordens na proliferação neuronal e/ou glial, na migração neuronal e/ou especialização, nos processos de padronização da linha média, no crescimento e/ou direcionamento axonal, e no desenvolvimento pós-direcionamento $(45,47)$. 


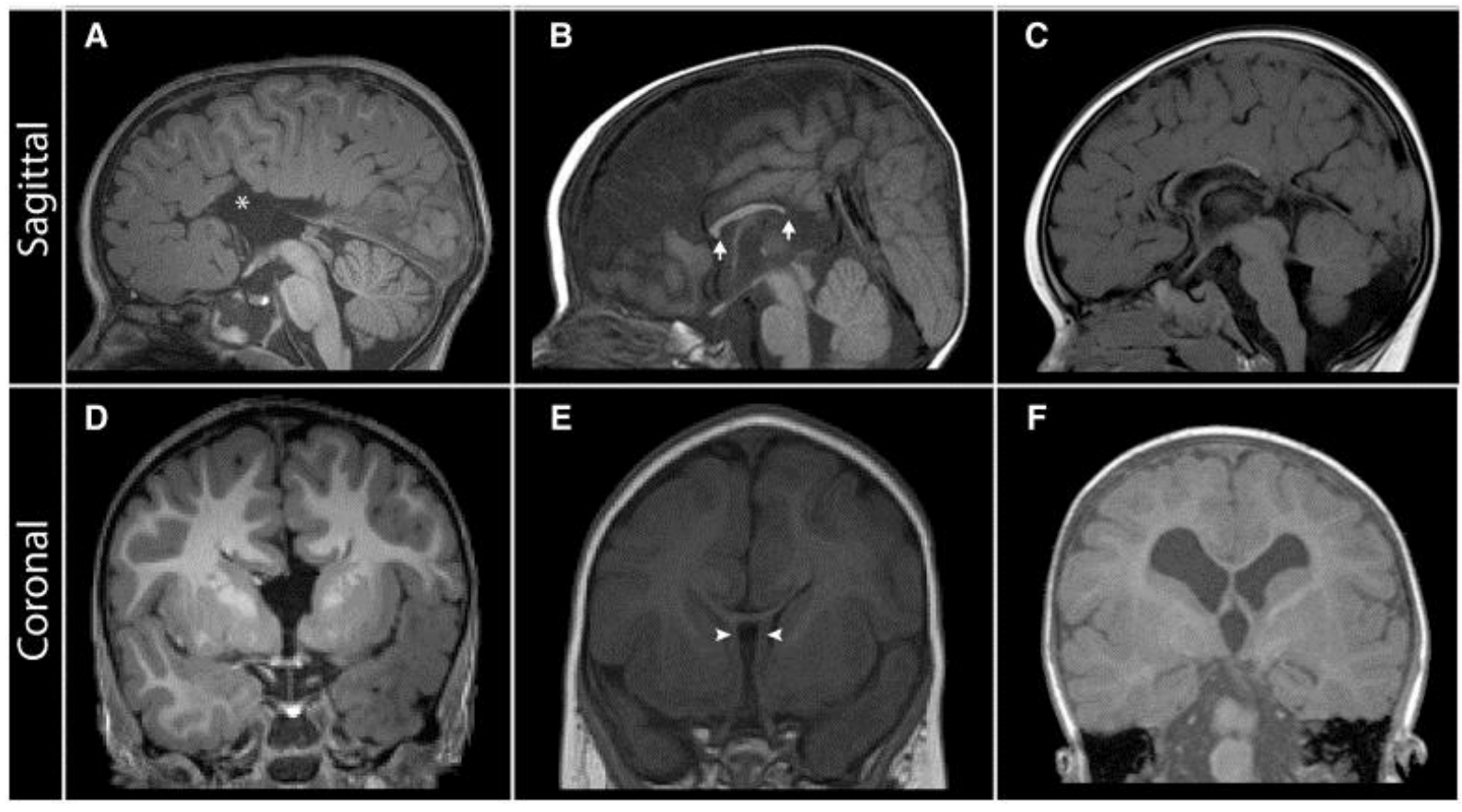

Figura 2. Achados neuroanatômicos revelados através dos cortes sagital e coronal em T1 no exame de RMN em pacientes com anormalidades no Corpo Caloso. A e D: paciente com ACC completa associada com expansão dorsal de terceiro ventrículo (asterisco), ausência do giro e sulco do cíngulo, e ausência do septo pelúcido. B e E: paciente com ACC parcial; o esplênio está ausente e o rostro não está completamente formado (setas), e as lâminas do septo pelúcido não estão fundidas (E; cabeças de setas). C e F: paciente com hipoplasia do CC, onde estão presentes todos os segmentos porém afilados, além de apresentar redução considerável no volume da substância branca cerebral (F). (adaptado de 40)

Tradicionalmente a ideia mais aceita é a de que o CC humano se desenvolvia no sentido antero-posterior possibilitando, assim, realizar a distinção entre as DCC primárias e as DCC secundárias. No entanto, mais recentemente, estudos de neuroimagem sugeriram que os primeiros axônios cruzam a placa comissural no hipocampo primordial, com subsequentes conexões sendo realizadas bidireccionalmente $(36,48)$. Portanto, durante a $13^{\mathrm{a}}$ e $14^{\mathrm{a}}$ semanas pós-concepção, axônios pioneiros começam a cruzar a linha média, as partes anteriores começam a crescer entre a $14^{a}$ e $15^{\text {a }}$ semana enquanto que a partes posteriores crescem por volta da $18^{\mathrm{a}}$ e $19^{\mathrm{a}}$ semanas. $\mathrm{O}$ aparente atraso no desenvolvimento da porção posterior em relação a anterior deu origem ao consenso de que interferências precoces no desenvolvimento do CC resultariam em ACC completa, enquanto que perturbações tardias resultariam em DCC primária limitada ao corpo caloso posterior e rostro. Por volta da $20^{\mathrm{a}}$ semana, o CC completa o seu formato achatado, embora o crescimento intenso de axônios ocorra até dois meses após o nascimento, período 
mais provável para a causa das DCC secundárias e hipoplasias. Embora o número de fibras calosas seja determinado, mais ou menos, ao nascimento, variações estruturais continuam ao longo do desenvolvimento pós natal e, particularmente, mais acentuadas durante a infância e adolescência $(36,49,50)$.

Ultrassonografias de rotina constituem a ferramenta primária na identificação de ACC a partir do segundo trimestre, quando pode ser visualizado o alargamento da fissura inter-hemisférica, a ausência da cavidade do septo pelúcido e a colpocefalia (51). Estes exames, entretanto, muitas vezes falham na detecção dos casos mais sutis de DCC ou de hipoplasia calosal mesmo quando associado com disgenesia da substância branca (52). Por esta razão, o mapeamento por exames de ressonância magnética nuclear (RMN) são a modalidade mais indicada para visualização direta do CC em casos de suspeita de ACC e de outras anomalias que não podem ser detectadas pelas ultrassonografias. Particularmente, isto é importante para o aconselhamento precoce aos pais, uma vez que anormalidades cerebrais identificadas pela RMN podem sugerir muitas desordens do neurodesenvolvimento que estão associadas com deficiências neurológicas mais graves $(46,53)$.

O desenvolvimento do CC ocorre simultaneamente ao cerebral e cerebelar, sendo assim a ACC é uma anomalia que pode ocorrer de forma isolada ou, mais frequentemente, em associação com outras malformações do SNC ou sistêmica, o que sugere que a ACC faça parte de um distúrbio do desenvolvimento mais generalizado. Anomalias do SNC podem incluir lipomas ou cistos inter-hemisféricos, encefalocele, microcefalia, malformação de Dandy-Walker (mais frequente) ou de Arnold-Chiari, holoprosencefalia, hidrocefalia, desordens de migração neuronal, heterotopias neuronais, lisencefalia, paquigiria, e esquizencefalia. Por conta da proximidade embriológica, a ACC está normalmente associada com malformações das estruturas do sistema límbico, particularmente a formação do septo e do hipocampo. Ademais, malformações sistêmicas incluem, com grande frequência, anomalias faciais, do sistema esquelético, do trato intestinal e genitourinário, e dos sistemas cardiovascular e respiratório $(54,55)$.

A incidência da ACC é de $0,3 \%$ a $0,7 \%$ na população geral e de $2 \%$ a $3 \%$ na população com deficiência intelectual. Dependendo da etiologia, o risco de recorrência varia de $1 \%$ (se for de herança esporádica ou cromossomal) a $25 \%$ (se for de herança autossômica recessiva) ou mesmo $50 \%$ em indivíduos do sexo 
masculino (se recessivo ligado ao X) (34). Glass e colaboradores (56) relataram uma prevalência de ACC ou hipoplasia do CC de 1,8 para cada 10.000 nascidos vivos, onde fatores como prematuridade e idade materna avançada foram os que mais aumentaram as chances do surgimento do distúrbio.

As consequências cognitivas e neurológicas nos pacientes com ACC variam consideravelmente desde problemas comportamentais amenos a graves deficiências neurológicas. Dentre os sinais e sintomas mais frequentemente associados à ACC estão DI (60\%), problemas visuais (33\%), atraso na fala (29\%) e convulsões $(25 \%)$ (33). Dificuldades na resolução de problemas e deficiências nas habilidades sociais são comuns, e muitas vezes incluem tendência ao transtorno do espectro autista $(57,58)$. Curiosamente, na maioria das vezes, a forma isolada da ACC possui prognóstico favorável (59), onde os indivíduos exibem um resultado cognitivo diferente dos observados na síndrome da desconexão inter-hemisférica caracterizada nos pacientes que foram submetidos à comissurotomia (60). Indivíduos com ACC são, portanto, uma oportunidade única de se estudar não apenas os mecanismos do desenvolvimento calosal, mas também os princípios gerais que determinam como 0 cérebro responde às interferências no neurodesenvolvimento. 


\subsubsection{As alterações genéticas envolvidas nas Malformações do Corpo}

\section{Caloso}

O aumento na frequência do uso e do poder de resolução dos exames moleculares que permitem a análise do genoma completo, como na CMA ou no estudo dos exomas, possibilitou identificar mais genes e loci genômicos envolvidos no desenvolvimento do $\mathrm{CC}$, e tem contribuído para ampliar a diversidade das causas genéticas nas síndromes que envolvem ACC (61).

Até o momento, $55 \%$ a $70 \%$ dos casos de ACC não possuem etiologia elucidada se considerar apenas a avaliação clínica (45). Aparentemente, as anomalias do CC possuem uma natureza circunstancial, o que dificulta a realização de estudos genéticos, visto que possivelmente a etiologia da ACC na maioria destes pacientes é de causas não genéticas, como nos casos de exposição alcoólica fetal. $\mathrm{Na}$ realidade, esta é uma associação frequente com anomalias cerebrais visualizadas nos exames de imagem que indicam claramente alguma anormalidade no processo do neurodesenvolvimento (45).

Cerca de $30 \%$ a $45 \%$ dos casos de ACC possuem causa genética desconhecida (45,62). A maior parte das síndromes que apresentam ACC possui herança mendeliana com penetrância incompleta, sendo descritas síndromes com herança autossômica dominante ou recessiva ou herança ligada ao cromossomo $X$ (56). Anomalias do CC estão relacionadas, também, com a presença de trissomias (ex: cromossomos 13 ou 18 ou trissomia em mosaico do 8), de rearranjos cromossômicos estruturais visíveis à citogenética tradicional (ex: rearranjo do 8p), e de um número crescente de CNVs detectadas por CMA. Distúrbios cromossômicos foram associados com $17 \%$ dos casos de ACC detectada antes do primeiro ano de vida (56).

O'Driscoll e colaboradores (61) publicaram uma revisão incluindo 374 pacientes novos e previamente descritos na literatura com ACC e alterações cromossômicas identificadas tanto por cariótipo convencional quanto por $\mathrm{CGH}$ array. Dentre as alterações cromossômicas mais frequentes estavam aquelas que envolviam os segmentos cromossômicos de 1q43-q44 (35 casos), 4p16 (15 casos), 8p22-p21 (21 casos) e 13q34 (22 casos). Outro ponto importante sugerido foi que as microdeleções da porção distal do braço longo do cromossomo 1 são as alterações cromossômicas mais frequentemente associadas à ACC. 
Dessa forma, as alterações cromossômicas constituem uma importante causa de ACC e a descrição de pacientes com essas anomalias pode auxiliar na identificação de genes associados com a etiologia da ACC. E mais, a maior parte do conhecimento a respeito do desenvolvimento normal do $\mathrm{CC}$ foi obtida através de estudos com cobaias com ACC. O entendimento dos processos que sustentam 0 desenvolvimento calosal em camundongos, por exemplo, serviu de alicerce para o conhecimento no âmbito da ACC em humanos (63). Estudos com cobaias são importantes para definição de processos críticos envolvidos no desenvolvimento do $\mathrm{CC}$, e evidências obtidas em análises de tecido neural em fetos humanos sugerem que processos e moléculas similares estão envolvidos no desenvolvimento do CC humano (64).

Entretanto, fenótipos em cobaias nem sempre podem ser correlacionados diretamente com os fenótipos em humanos, uma vez que não estão claros quais os mecanismos do desenvolvimento que estão conservados entre as espécies. Uma contribuição importante provém dos estudos de neuroimagens que preenchem esta lacuna e fornecem um meio de se examinar o desenvolvimento e as estruturas do cérebro humano $(54 ; 65)$. Outro fator limitador para se transferir o conhecimento alcançado com cobaias diretamente para o que ocorre em humanos, é que muitos modelos com o gene alvo mutado morrem embrionariamente ou no pós-natal, uma vez que normalmente estes genes regulam múltiplas etapas do desenvolvimento (66).

De forma similar, pacientes sem um ou mais genes funcionais são menos comuns do que aqueles com mutações de ponto em tais genes, tanto herdadas quanto de novo (66). Neste caso, estas mutações diminuiriam ou impediriam a função de um gene sem, contudo, torná-lo completamente não funcional. Sendo assim, estudos de genes candidatos para ACC realizados em camundongos com mutações completas, podem não ser a melhor forma de associar com os fenômenos que ocorrem em humanos (67). 


\subsection{PLATAFORMAS DE ANÁLISE CROMOSSÔMICA POR MICROARRANJOS (CMA)}

A Hibridação Genômica Comparativa $(\mathrm{CGH})$ foi uma das primeiras técnicas eficientes no rastreamento em busca de CNVs no genoma completo. Foi descrita pela primeira vez em 1992, por Kallioniemi e colaboradores (68), onde o DNA genômico total de uma amostra de tumor e de cultura de células de referência foram diferencialmente marcados e hibridados com cromossomos metafásicos. As diferentes intensidades de sinais produzidas à partir desta hibridação, em determinado local do genoma, representariam a relação proporcional do número de cópias entre as sequências dos genomas teste e referência. Considerando o genoma referência como normal, então aumentos ou diminuições nas taxas da intensidade dos sinais indicariam, diretamente, uma CNV no DNA da amostra testada. Alguns anos mais tarde, a técnica passou a ser realizada com arranjos de grandes sondas de DNA, sendo nomeada CGH-array ou aCGH, obtidas através de clones de cromossomos artificiais de bactérias (BACs), imobilizados em suportes de vidro (chips) de forma ordenada $(69,70)$.

Inicialmente, diversas técnicas de PCR foram adaptadas para contornar a dificuldade de se produzir BAC DNA com a pureza adequada para a realização dos arrays $(71,72,73,74,75)$. Esses clones de BACs possuíam comprimento variando entre 80.000 e 200.000 mil bases e, por serem menores que os cromossomos metafásicos em várias ordens de magnitude, a resolução teórica do CGH-array é proporcionalmente maior que a da $\mathrm{CGH}$ tradicional. O nível de resolução é determinado considerando tanto o tamanho da sonda quanto a distância genômica entre as sondas de DNA (76). A resolução dos arrays então foi aumentando à medida que sondas mais curtas passaram a ser utilizadas como alvo, começando por pequenos fragmentos de cDNA (77), passando por produtos de PCR (78) até chegar nas sondas de oligonucleotídeos $(79,80)$, possibilitando assim a inclusão de maior número de sondas por chip.

Paralelo à diminuição do comprimento das sondas ocorreu o surgimento dos primeiros BACs cobrindo todo o genoma humano e, com isso, a técnica teve um desenvolvimento extraordinário devido à sua capacidade de analisar um grande número de loci em paralelo no genoma completo (75). A primeira geração de $C G H$ array foi marcada pelos então denominados BAC-arrays, estes possuíam em média 
3.000 a 6.000 sondas mapeadas e representativas do genoma, que eram clonadas aos milhares de cópias e imobilizadas em lâminas de vidro para a reação de hibridação. Apesar da resolução desta metodologia específica ser considerada baixa atualmente, ainda assim, é cerca de 100 vezes maior do que a do cariótipo convencional, ou seja, a resolução do $\mathrm{CGH}$-array alcançava um milhão de bases (1 $\mathrm{Mb}$ ), enquanto que no exame da citogenética convencional alcança uma resolução máxima de $5 \mathrm{Mb}$. A diferença média da distância entre duas sondas no genoma era de 0,5 a $1 \mathrm{Mb}$, podendo variar consideravelmente, dependendo da região do genoma investigada (81).

Em pouco tempo os BAC-arrays foram substituídos pelos $\mathrm{CGH}$-arrays comercialmente disponibilizados que utilizavam chips contendo oligonucleotídeos de DNA, fato que permitiu um aumento substancial na cobertura genômica (9). Esta segunda geração da técnica era caracterizada por lâminas de vidro manufaturadas através de fotolitografia para acomodar entre 44.000 e 72.000 sondas com comprimento que variam, de acordo com os fabricantes, entre 25 a 85 bases. Com isso foi possível alcançar uma maior cobertura de regiões genômicas, ou seja, maior resolução na análise de variações do número de cópias de trechos de DNA no genoma (29). Diferentes plataformas que trabalham com oligonucleotídeos são oferecidas por grandes multinacionais da área de citogenômica, tais como Agilent, Affymetrix, NimbleGen e Illumina, cada qual apresentando vantagens técnicas próprias e que dependem do objetivo do estudo (científico ou clínico), de resolução máxima necessária para o array, e da expertise para a interpretação dos dados obtidos. O método tornou-se amplamente utilizado tanto para investigar pacientes com alterações cromossômicas aparentemente equilibradas (analisados por cariótipo convencional), mas com fenótipos anormais, quanto para o rastreamento ao longo do genoma de defeitos cromossômicos que podem representar a evidência inicial para a identificação de um ou mais genes associados a doenças genéticas (6).

A terceira geração da técnica foi marcada pela comercialização dos SNP arrays de alta resolução que utilizam chips que ultrapassam os 2,5 milhões de sondas, correspondendo a uma resolução de cerca de 1 a 100 kb (100 a 10.000 vezes maior do que a do cariótipo convencional), e que apresentam sondas para análise específica de polimorfismo de um único nucleotídeo ou SNP (do inglês, Single Nucleotide Polymorphism)(82). Tal avanço somente foi possível com o constante 
aprimoramento na fabricação dos chips, o que permitiu aumentar a densidade de sondas por chip, e com a evolução das tecnologias de detecção cada vez mais precisas e sofisticadas, que permitiram a detecção de alterações muito menores e a análise de um número maior de genes (83).

Na última década a CMA ampliou a detecção de alterações cromossômicas em pacientes com DI e/ou malformações congênitas e auxiliou na identificação de genes que contribuem para a ocorrência destas condições $(84,85)$. A busca genômica de CNVs em sequências de DNA por CMA permitiu detectar cada vez mais rearranjos cromossômicos crípticos recorrentes, os quais podem caracterizar síndromes genéticas definidas, ou pouco recorrentes, permitindo caracterizar melhor os quadros clínicos associados a esses rearranjos e indicar as regiões cromossômicas com maior susceptibilidade à ocorrência de fenômenos (86). Diversas síndromes, clinicamente bem caracterizadas previamente, foram associadas à presença de rearranjos submicroscópicos, dentre elas as Síndromes de Wolf-Hirschhorn (MIM \#194190), Williams-Beuren (MIM \#194050), DiGeorge (MIM \#188400) e LangerGiedion (MIM \#150230) (87). Por outro lado, levou a descrição de alterações cromossômicas recorrentes que puderam caracterizar novas síndromes, tais como as condições que envolvem a deleção 1p36 (MIM \#607872), a deleção 15q24 (MIM \#613406) e a Síndrome de Potocki-Lupski (MIM \#610883) (87,88). Contudo, diversas outras CNVs submicroscópicas ainda apresentam poucos relatos descritos não permitindo uma caracterização fenotípica bem definida. 


\subsubsection{Oligoarrays e SNP-arrays}

No CGH-array tradicional o DNA de um paciente e o de um controle são fragmentados e depois marcados por dois fluorocromos distintos para, em seguida, serem hibridados com oligonucleotídeos de DNA depositados sobre uma lâmina de vidro. Por fim, realiza-se a leitura por meio de escâner a laser e a captação dos sinais emitidos por cada fragmento hibridado. $O$ resultado desta análise será obtido a partir da razão das intensidades de fluorescência dos dois fluorocromos após a reação de hibridação, onde será possível detectar aneuploidias, tais como as deleções e/ou duplicações, no genoma da amostra testada, em um único ensaio e em qualquer região genômica coberta pelas sondas. Entretanto, neste caso, as alterações cromossômicas equilibradas, tais como translocações ou inversões, não poderiam ser detectadas, limitando este tipo de array ao diagnóstico de microdeleções e microduplicações genômicas (6).

No caso dos SNP-arrays, mais modernos, um único DNA testado é hibridado diretamente com as sondas do chip sem a necessidade de DNA referência. Além das CNVs, informações genômicas obtidas pelos SNP-arrays permitem detectar trechos de homozigose e, portanto, identificar doenças causadas por genes recessivos, aneuploidias por mosaicismo e dissomia uniparental ou UPD (do inglês, Uniparental Disomy) (89,90). Nos chips mais comuns de SNP-arrays existem conjuntos de sondas específicos que permitem a genotipagem paralela de 10.000 a mais de 1 milhão de SNPs através da identificação dos quatro variantes possíveis ( $A, C, T$ ou $G$ ) na sequência contendo o SNP (91). Estas novas metodologias têm permitido demonstrar a importância das variações quantitativas no genoma, inclusive possibilitando demonstrar que existem variantes de tamanhos diversos deletados ou duplicados e INDELS (inserções/deleções) no genoma das pessoas fenotipicamente normais, (92-94).

Os SNPs constituem uma das classes de variabilidade mais comuns no genoma humano, sendo encontrados um polimorfismo desta natureza, em média, a cada 1.000 pb. Apesar de serem estimados existirem mais de 19 milhões de SNPs nas populações humanas ao redor do mundo, pouco mais de 3 milhões foram documentados pelos bancos de dados públicos. Atualmente, são realizados grandes esforços internacionais para validar a frequência de cada variante. Aproximadamente $70 \%$ dos SNPs estão localizados nos introns, embora seu papel 
não esteja claro ainda e a maioria seja silenciada, algumas destas sequências parecem impactar na expressão gênica ou no processo do splicing. Os SNPs são capazes de revelar a variação genômica em uma escala tão ampla que é impossível de se alcançar com os outros tipos de polimorfismos do DNA, consequência da sua ubiquidade e da rápida genotipagem permitida pelas tecnologias atuais (95).

Embora as técnicas de arrays ainda não tenham atingido a maturidade e, não exista consenso sobre qual plataforma proporciona o melhor equilíbrio entre a densidade de sondas, a cobertura do genoma, e a menor complexidade das análises, estas tecnologias têm fornecido capacidade diagnóstica nunca antes experimentada no campo da Citogenética $(27,96,97)$.

Diversos estudos e importantes instituições, incluindo American College of Medical Genetics and Genomics e Clinical Genome Resource, anteriormente conhecido como ISCA, recomendam realizar primeiramente a investigação com as tecnologias do CMA em pacientes com DI, autismo ou malformações, antes do cariótipo convencional. Os casos em que o cariótipo deve ser primeiramente utilizado são aqueles em que há suspeitas de síndromes conhecidas (por exemplo, Síndrome de Down - MIM \#190685), em que há histórico familiar de rearranjos cromossômicos ou histórico de múltiplos abortos (6, 29, 94, 98-103)

Com a disseminação dos arrays nos centros de pesquisa e de diagnósticos, os avanços inevitáveis nas tecnologias permitiram combinar e ampliar as vantagens e capacidades das técnicas, como no caso da plataforma CytoScan ${ }^{\circledR}$ Array (Affymetrix, EUA), que conciliou o alto poder de resolução na detecção de CNVs que os arrays de oligonucleotídeos possuem com a maior sensibilidade na detecção de consanguinidade, UPD e mosaicismo dos SNP-arrays. Além disso, tornou possível detectar pequenas microdeleções ou microduplicações que estão presentes em quase metade das translocações aparentemente equilibradas, contornado uma das principais desvantagens quando se utiliza as plataformas de menor resolução. (28, $29,100,103)$. 


\subsubsection{Taxa diagnóstica por meio da CMA}

Investigações sistemáticas por CMA nos indivíduos afetados por DI sindrômica mostraram uma taxa de detecção de microdeleções/microduplicações variando entre de 10 e $20 \%$ de acordo com a população estudada, a seleção dos pacientes e a plataforma utilizada; comparado à taxa de aproximadamente 3\% (excluindo a trissomia do cromossomo 21) utilizando as abordagens citogenéticas convencionais (32, 104-106).

O rendimento diagnóstico do $\mathrm{CGH}$-array é elevado quando realizado em crianças com DI idiopática, múltiplas anomalias congênitas e cariótipo normal, detectando desequilíbrios genômicos em 10-15\% dos casos (96) e, quando é utilizado como primeira técnica diagnóstica, em 33\% dos casos, (107). E mais, a taxa de diagnóstico por CGH-array é mais elevada em comparação com o diagnóstico por cariótipo convencional em gestações com anomalias detectadas por ultrassonografia (108).

Em 2006, no estudo brasileiro pioneiro de Krepischi-Santos e colaboradores (109), identificaram alterações cromossômicas não descritas previamente em 17\% dos pacientes testados. Dessa forma, a triagem de microdeleções em pacientes com DI não sindrômica e malformações congênitas múltiplas é essencial para a identificação da etiologia do quadro clínico e pode contribuir para agregar um maior número de casos descritos de microrrearranjos raros (110). Em outro estudo recente realizado em um grupo de neonatos com anomalias congênitas de etiologia desconhecida, a análise de CGH-array teve taxa de detecção de 14,3\% (111). 


\subsection{VARIAÇÕES NO NÚMERO DE CÓPIAS (CNVS): CLASSIFICAÇÃO E INTERPRETAÇÃO}

Com o advento dos exames que analisam o genoma completo foi possível reconhecer que parte da diversidade do genoma se deve à presença de CNVs nas regiões genômicas. Estas variações respondem por muito da diversidade que existe dentro da população e são um poderoso mecanismo que contribui para a evolução em primatas, por alterações não em pontos, mas em blocos de DNA. Assim como os SNPs, as CNVs são, portanto, fatores que contribuem muito para a diversidade do genoma. As CNVs, no entanto, tem uma importante contribuição para a ocorrência de doenças genéticas $(84 ; 85)$.

Inicialmente CNVs eram consideradas apenas diferenças no número de cópias de genes entre indivíduos em um loci específico (por exemplo: nos locus alfa e beta do gene da globina), ou um desequilíbrio genômico resultante em doenças como nas Síndromes de Prader-Willi (MIM \#176270) e Angelman (MIM \#105830), ou seja, até pouco tempo atrás eram consideradas rearranjos no genoma humano de escala limitada. Desde 2004, entretanto, estudos utilizando plataformas de arrays revelaram que as CNVs existem na maioria dos indivíduos normais na forma de grandes segmentos de DNA, sendo considerada a maior fonte de variação genética humana (92, 93, 112, 113).

O nível, sem precedente, de diversidade genética conferida pelas CNVs inaugurou um novo capítulo no entendimento sobre a variação fenotípica, evolução humana e susceptibilidade a doenças. Estas deleções, inserções ou duplicações maiores que $1 \mathrm{~Kb}$ em comprimento ocorre em torno de $12 \%$ no genoma humano e tendem a aparecer em regiões com sequências genéticas repetitivas como é o caso dos Low Copy Repeats (LCRs). Algumas CNVs são comuns e transmitidas ao longo das gerações enquanto outras aparecem de novo e de forma recorrente. Acredita-se que as CNVs mais raras são as que apresentam maior probabilidade de serem patogênicas $(93,114)$.

As CNVs são as variações e polimorfismos (SNPs, INDELs, microssatélites, minissatélites, inversões, translocações e CNVs) que constituem a dinâmica arquitetura do genoma humano e fundamentam as diferenças entre as pessoas (115). Com o auxílio da tecnologia dos arrays as primeiras CNVs descritas e estudadas (476 loci de CNV em 75 indivíduos) afetavam loci com genes que 
exercem papel importante em funções neurológicas e metabólicas (112). Desde então, mais CNVs foram descritas, principalmente, à partir de dados de genotipagem de SNPs $(113,115)$.

Em 2006 surgiu o primeiro mapa de CNVs baseado em 270 indivíduos de diferentes grupos étnicos originalmente incluídos no Projeto HapMap Internacional. Redon e colaboradores (93) publicaram uma lista de 1447 regiões de variações de número de cópias (CNVRs), correspondendo a 360 Mb (ou 12\%) das sequências do DNA humano. Estas regiões não apresentavam distribuição uniforme ao longo do genoma e tinham funções genômicas envolvendo mecanismos de adesão celular e percepção sensorial olfativa e processos neurofisiológicos. Estavam concentradas próximas a segmentos de duplicação (SDs) que, posteriormente, outros estudos definiram como hotspots para rearranjos cromossômicos e CNVs $(116,117)$.

À medida que os estudos foram descobrindo e caracterizando novas CNVs, as plataformas de detecção foram amadurecendo e novas tecnologias emergiram trazendo novas perspectivas e variações estruturais das CNVs, inclusive ganhando nova dimensão com relação às doenças genéticas $(115,118)$.

Lupski (119) denominou "doenças genômicas" condições que muitas vezes tem um caráter recorrente e são consequência de erros ocorridos durante a recombinação meiótica provocando a formação de cromátides desiguais, que apresentam perdas e ganhos recíprocos de material genético. Existem regiões do genoma, em particular as que têm regiões repetidas e invertidas, que favorecem a ocorrência deste tipo de alteração (85).

A detecção de CNVs raras e comuns por meio das plataformas de arrays tem gerado questões acerca da origem e dos mecanismos moleculares que levam a CNVs serem recorrentes ou não recorrentes $(120,121)$, e dos efeitos fenotípicos das CNVs e seu risco de recorrência (122). Por trás de sua formação estão diversos mecanismos diversos mecanismos de mutação, recombinação meiótica dirigida com e sem homologia, reparação de quebras de dupla cadeia de DNA e erros na replicação (115). Curiosamente, como as CNVs são extremamente comuns na população o número presente em cada indivíduo não é proporcional a patologia que ele apresenta (92).

Com as técnicas de CMA a detecção de CNVs aumentou tanto em indivíduos afetados por alguma patologia como em pessoas saudáveis (123). McCarroll e colaboradores (113) demonstraram que as variações nos genomas dos indivíduos 
resultam em diferenças no nível de expressão dos genes envolvidos, implicando no efeito adaptativo destas alterações uma vez que estão presentes em indivíduos saudáveis. A maior dificuldade que os pesquisadores encontram, portanto, é interpretar o significado clínico das CNVs, uma vez que a maioria se encontra em regiões pobres ou ausentes de genes e podem, portanto, serem neutras ou terem efeitos reguladores modestos (115). Estabelecer a possível consequência do desequilíbrio provocado por uma CNV pode ser mais facilmente interpretada quando estão localizadas dentro de genes ou regiões reguladoras (124). No entanto, mesmo alguns destes casos podem dificultar a interpretação quando ocorre, por exemplo, uma expressão variável do alelo remanescente e/ou penetrância incompleta que podem causar consequências clínicas diferentes nos membros de uma mesma família $(125,126)$.

Uma das primeiras classificações de CNVs foi proposta pelo estudo de Lee, lafrate e Brothman (127) e, desde então, diversas propostas na classificação foram surgindo à medida que o conhecimento e as informações foram aumentando à respeito da grande diversidade de CNVs $(26,128,129)$. Srebniak e colaboradores (130) recentemente propuseram nova forma de classificar genericamente as CNVs a partir dos resultados encontrados pelos arrays, incluindo assim nomenclatura mais simples e subcategorias para alguns achados clínicos importantes que historicamente foram subestimados. Assim a classificação facilita desde qual a informação a ser disponibilizada para o paciente, enfoca na real necessidade de como descrever a alteração, e considera se a alteração possui ou não penetrância e/ou expressividade variáveis conhecidas.

Seguindo por este caminho temos: primeiro, as variações patogênicas para o probando que podem ser subclassificadas em achados causais, que agrupa os casos onde a alteração tem clara correlação com o fenótipo ou a indicação clínica (ex: microdeleção 22q11 em um indivíduo com tetralogia de Fallot - MIM \#187500); diagnósticos imprevistos, que agrupa todas as situações onde a alteração não explica o fenótipo ou indicação clínica; loci susceptíveis, que inclui casos onde as variações estão associadas com desordens do neurodesenvolvimento, mas possuem heterogeneidade fenotípica e/ou expressividade variável (ex: deleção $6 p 21.1$ em paciente com atraso no desenvolvimento). Segundo, as variações de significado clínico desconhecido ou VOUS (do inglês, Variants of Unknown Significance), que nesta nova classificação incluem as que são potencialmente 
patogênicas (sem evidências suficientes), as que são VOUS verdadeiras (significado desconhecido) e as aparentemente benignas (sem evidências suficientes de benignidade). Terceiro, as variações benignas, que representam as variações benignas (encontradas nos indivíduos sadios) e polimórficas (encontradas em $>1 \%$ na população em geral). Quarto, as variações potenciais para distúrbios de caráter recessivo, onde uma desordem recessiva bem caracterizada, com uma frequência razoavelmente elevada na população e/ou aspectos clínicos consistentes com a indicação do paciente, pode ser referida (ex: deleção do gene CFTR - OMIM 602421). E, finalmente, as variações acidentais, que incluem as anomalias encontradas ao acaso, não intencionalmente, nos parentais dos probandos (ex: síndrome de Turner em mosaico, descoberta em gráfico de frequência B-alélica, por meio da análise do controle de qualidade do array de uma gestante indicada para diagnóstico pré-natal por conta de malformações na ultrassonografia fetal) (130).

A maneira mais confiável de se determinar a relevância clínica de uma CNV para um indivíduo é compará-la com as CNVs reunidas em grandes bancos de dados (131). Desta forma, CNVs que são encontradas em grandes grupos controle (populações não afetadas), e que, por este motivo, não parecem estar associadas a nenhum quadro clínico, devem ser classificadas como CNVs benignas (132). As CNVs benignas estão presentes em cerca de $6 \%$ do genoma humano e não impactam no fenótipo do indivíduo (133). A ausência de genes em uma CNV não permite necessariamente classificá-la como benigna, já que na região afetada podem conter sequências reguladoras essenciais para a expressão de genes vizinhos. Vale lembrar que muitas vezes, CNVs que envolvem genes que possuem ampla variedade com relação ao tamanho e número de repetições acabam dificultando a interpretação dos resultados encontrados pela CMA, visto que eles podem apresentar um maior número de cópias em indivíduos com um quadro clínico considerado normal (134)

As CNVs patogênicas estão descritas nos bancos de dados e na literatura como causadoras de síndromes bem caracterizadas, suas regiões contêm genes ou regiões subteloméricas, conhecidamente ricas em genes, associados às doenças (86).

As CNVs com potencial patogênico possuem genes relevantes na região alterada que ainda não possuem relação com síndromes conhecidas, e não são encontradas em grande número na população (135). 
Por outro lado, as VOUS não são observadas na população normal, possuem genes de função pouco conhecida ou RNA não codificante e, portanto, a interpretação de seu papel no fenótipo constitui um desafio para os pesquisadores (135).

Para correlacionar CNVs com os fenótipos dos indivíduos, alguns critérios devem ser obedecidos antes que qualquer conclusão seja feita: precisam ser analisados, consultados e comparados o tamanho, o número, e os genes afetados com as informações que constam nos bancos de dados (127; 136). Com isso, a descrição de microrrearranjos cromossômicos raros torna-se importante para determinar a etiologia do quadro clínico dos afetados, caracterizar novas síndromes genéticas, e elucidar os mecanismos de formação de rearranjos cromossômicos (86).

Esforços internacionais permitiram criar plataformas de coleta e comparação de dados citogenéticos moleculares obtidos em diversos centros de genética clínica espalhados pelo mundo. Esses bancos ajudam, principalmente, a melhorar a compreensão do papel que as CNVs exercem na DI e em outros distúrbios genéticos. Por exemplo, o Database of Genomic Variation ou DGV (http://dgv.tcag.ca/dgv/app/home) é um banco que agrega as informações descritas de mais de 2,5 milhões de alterações estruturais presentes mais de 22.300 indivíduos controles de populações de mundo todo (137). Por outro lado, o Database of Chromosomal Imbalance and Phenotype in Humans using Ensembl Resources ou DECIPHER (https://decipher.sanger.ac.uk) compila os dados sobre as mais de 26 mil CNVs e 47 mil dados fenotípicos encontrados em mais de 17,5 mil indivíduos estudados por centenas de projetos ao redor do mundo (138).

A crescente quantidade de informações disponibilizadas por diferentes bancos de dados permite estabelecer relação entre uma determinada CNV e uma possível condição patogênica com precisão cada vez maior (135). Para os casos de CNVs que não possuem uma interpretação estabelecida, é necessário analisar clinicamente e geneticamente os pais biológicos do probando. Caso seja configurada a herança de um genitor assintomático, torna-se menos provável atribuir a causa do problema apresentado pelo indivíduo à alteração (139). 


\section{JUSTIFICATIVA}

O espectro do quadro clínico em pacientes que apresentam malformações CC é amplo e heterogêneo. E quando acompanhado de outras anomalias estruturais e/ou ADNPM e/ou DI possui uma etiologia genética que, na maioria das vezes, não é conhecida. Desta forma, estes indivíduos e estas alterações são um tema de grande interesse para os estudos científicos e clínicos não apenas pelo fato de suas características e mecanismos serem pouco conhecidos, mas também porque, além dos indivíduos poderem sofrer prejuízos cognitivos e sociais, a evolução e o aumento na sensibilidade e precisão das técnicas de diagnóstico têm contribuído para elevar as chances de se encontrar um diagnóstico específico para cada condição. Na última década, diversos estudos melhoraram a compreensão dos mecanismos e do impacto das variações genômicas sobre as alterações fenotípicas aumentando, por consequência, a necessidade e o interesse de se investigar como e quais CNVs causam as anomalias do CC. Embora a técnica de CMA ainda não tenha alcançado o seu auge, ela se tornou cada vez mais comum e, consequência disso, são as várias informações que contribuem de forma relevante para 0 entendimento dos mecanismos genéticos que envolvem os distúrbios do neurodesenvolvimento e do $\mathrm{CC}$. Além dos conhecidos prejuízos aos pacientes com anomalias do CC, a escassez de informações e de estudos deste tipo no Brasil aliado ao sofrimento da família e aos elevados custos exigidos com a atenção são fatores que justificam todos os esforços neste campo. Embora Davila-Gutierrez e colaboradores (43) tenha estimado o número de 3 crianças com malformação do CC para cada 1000 nascimentos, conhecer os índices de prevalência é de fundamental importância para a implementação de políticas públicas voltadas para os cuidados relativos às doenças crônicas, como a ACC. Desta forma, tornam-se cada vez mais necessários estudos sobre as características genéticas, clínicas e neurofisiológicas das malformações do CC com vistas a auxiliar no aconselhamento genético e familiar dos indivíduos afetados. 


\section{OBJETIVOS}

\subsection{OBJETIVO GERAL}

Pretende-se com a realização deste estudo:

> Pesquisar a presença de CNVs no genoma completo de pacientes atendidos nos Serviços Públicos de Genética Médica no Distrito Federal, com ACC completa ou parcial e/ou alguma malformação estrutural e/ou neuropsicomotora;

\subsection{OBJETIVOS ESPECÍFICOS}

Contribuirá para alcançar os objetivos gerais:

a) Implantar a metodologia da Análise Cromossômica por Microarranjos (CMA) para os Serviços Públicos de Genética Médica no Distrito Federal;

b) Determinar a frequência de CNVs raras em indivíduos com ACC por meio da CMA;

c) Contribuir com a identificação de novas regiões genômicas associadas à ACC;

d) Propor genes candidatos a ACC mapeados pela CMA 


\section{METODOLOGIA}

\subsection{SELEÇÃO DE PACIENTES, CARACTERIZAÇÃO DA AMOSTRA E CONSIDERAÇÕES ÉTICAS:}

Para este estudo, foram selecionados um grupo de 60 pacientes atendidos no Núcleo de Genética no Hospital de Apoio de Brasília (NUGEN/HAB) da Secretaria de Saúde do Distrito Federal (SES/DF) e no Serviço de Genética Médica do Hospital Universitário da Universidade de Brasília (HUB/UnB). Os pacientes que tinham quadro de ACC completa ou parcial, detectadas por exames de ultrassonografia transfontanela (USTF) no período neonatal ou de Tomografia de Crânio (TC) e/ou RMN de crânio e encéfalo, associadas com DI sem caracterização de síndrome genética definida e/ou com alguma malformação estrutural, foram convidados a participar da pesquisa. As solicitações dos exames foram feitas pela equipe de médicos geneticistas do NUGEN e do HUB, entre o período de março de 2011 e novembro de 2014.

Os responsáveis legais dos pacientes que concordaram em participar preencheram e assinaram um termo de consentimento livre e esclarecido (TCLE) após o esclarecimento das etapas e da importância do projeto. A proposta do estudo foi submetida e aprovada pelo Comitê de Ética em Pesquisa da Faculdade de Medicina da Universidade de Brasília (CEP-FM/UnB) como parte do projeto interinstitucional intitulado "Investigação da Etiologia do Retardo Mental Sindrômico" (ANEXO A).

Foram coletados de 4 a $8 \mathrm{~mL}$ de sangue periférico do paciente e de seus pais em tubo contendo EDTA (ácido etilenodiaminotetraacético) como anticoagulante, sendo cada indivíduo identificado por um código. Em seguida, o material biológico foi encaminhado para extração no laboratório de Biologia Molecular do NUGEN.

Cada médico dos Serviços de Genética do NUGEN e do HUB que solicitou o exame do SNP-array concordou em participar deste trabalho contribuindo, também, com informações à partir da clínica e do prontuário do paciente, incluindo tipo de exame que detectou a alteração do $\mathrm{CC}$ e resultado do exame do cariótipo. Os dados clínicos incluiam grau de comprometimento intelectual, presença/ausência de dismorfias, presença/ausência de malformações, além de outras particularidades clínicas. Quando necessário para complementar os achados fenotípicos dos 
pacientes, fotografias foram disponibilizadas pelos médicos colaboradores do estudo. A identidade dos pacientes foi mantida anônima e apenas os médicos e os responsáveis pela pesquisa tinham acesso às informações confidenciais.

\subsection{ISOLAMENTO E QUANTIFICAÇÃO DO DNA GENÔMICO}

A extração do DNA genômico foi realizada utilizando kit comercial de extração Wizard $^{\circledR}$ Genomic DNA Purification (Promega, EUA), segundo as especificações do fabricante. A concentração de DNA (ng/ $\mu \mathrm{L}$ ) existente em cada amostra foi quantificada em um espectrofotômetro Nanodrop ${ }^{\circledR} 2000$ (Thermo Scientific, EUA). Todas as amostras foram armazenadas a $-20^{\circ} \mathrm{C}$.

\subsection{ANÁLISE CROMOSSÔMICA POR MICROARRANJOS (CMA)}

A técnica de CMA permite identificar microdeleções ou microduplicações ou perdas de heterozigose em milhares de sequências alvo do genoma humano. Esta técnica utiliza como alvo de hibridação um conjunto de sondas (oligonucleotídeos), com localização previamente conhecida nos cromossomos, organizados em alta densidade em um chip de DNA $\left(\right.$ GeneChip $\left.^{\circledR}\right)(84,85)$. A investigação da presença de alterações cromossômicas submicroscópicas por CMA em pacientes com ACC foi feita utilizando a plataforma CytoScan ${ }^{\circledR} 750 \mathrm{~K}$ Array (Affymetrix, EUA) e as configurações disponíveis no GeneChip ${ }^{\circledR}$ Scanner 3000 7G System (Affymetrix, EUA). Esta plataforma permite a detecção de CNVs por meio de microarranjos de DNA formados por 550 mil sondas não polimórficas para CNVs de regiões codantes e não codantes do genoma humano, cobrindo uma distância média de $4.1 \mathrm{~Kb}$, e cerca de 200 mil sondas de SNPs (Figuras 3a e 3b).

A produção do GeneChip $^{\circledR}$ desenvolvido pela Affymetrix envolve processos de fotolitografia para sintetizar microarranjos de milhares de cópias de oligonucleotídeos (25 nucleotídeos de comprimento) selecionados. Estes oligonucleotídeos, chamados de sondas, irão constituir centenas de milhares de diferentes células específicas chamadas features. Cada célula do chip tem um tamanho de 5 x 5 micrômetros $(\mu \mathrm{m})$, e possui uma posição bem determinada. Cada SNP conta com 3 réplicas para cada alelo espalhadas em várias regiões do chip proporcionando medições múltiplas e independentes de cada região genômica, 


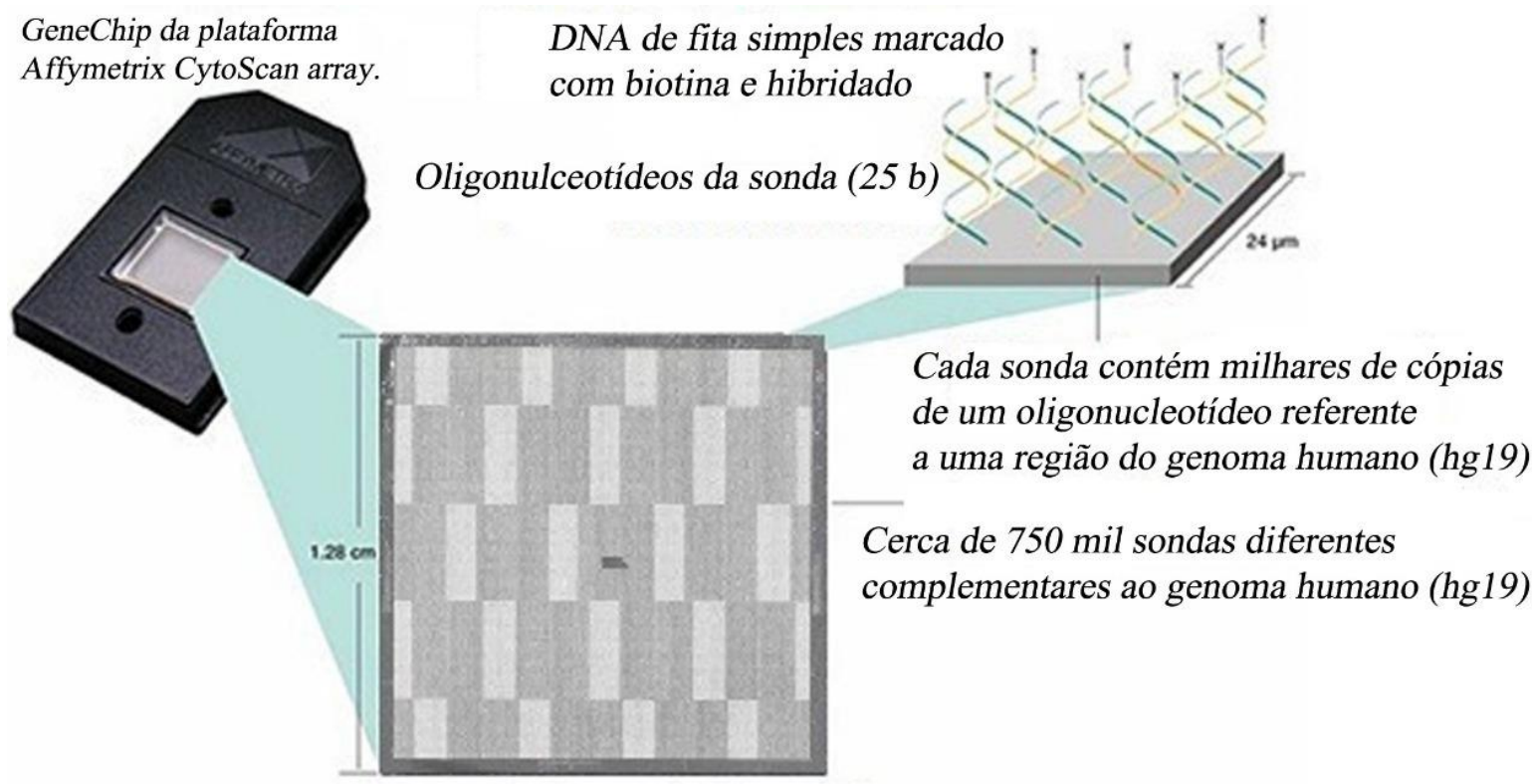

(a) Imagem captada pelo Scanner $30007 G$ (Affymetrix) referente aos diferentes níveis de fluorescência emitidos de acordo com as sondas hibridadas no GeneChip.

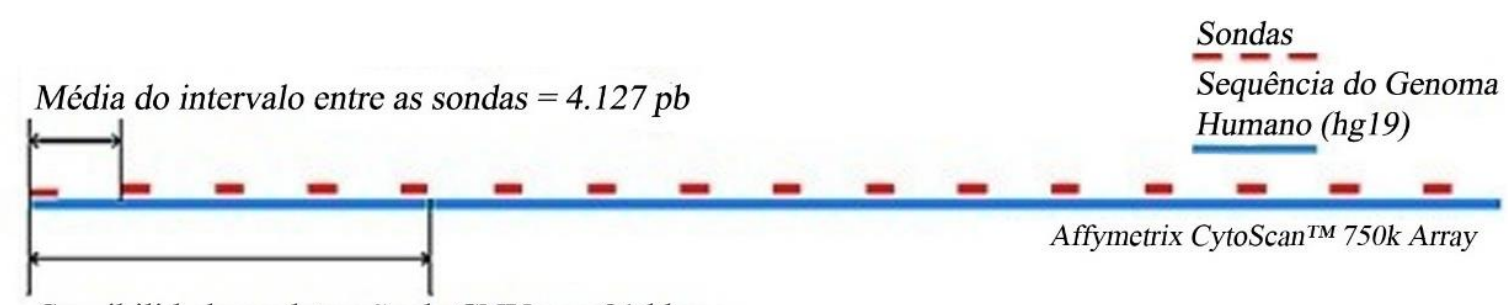

Sensibilidade na detecção de $C N V s=\sim 21 \mathrm{~kb}$

Distância média entre as sondas nas regiões intragênicas $=1.737 \mathrm{pb}$

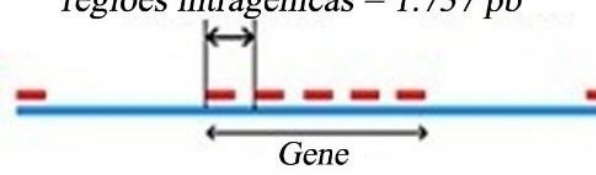

Distância média entre as sondas nas regiões intergênicas $=6.145 \mathrm{pb}$

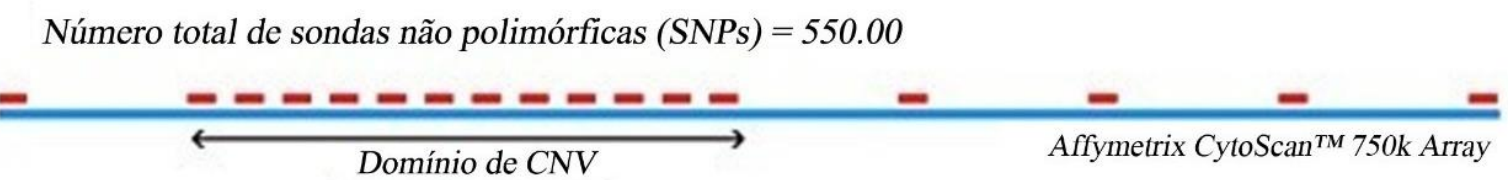

Número de sondas polimórficas $($ SNPs $)=200.436$

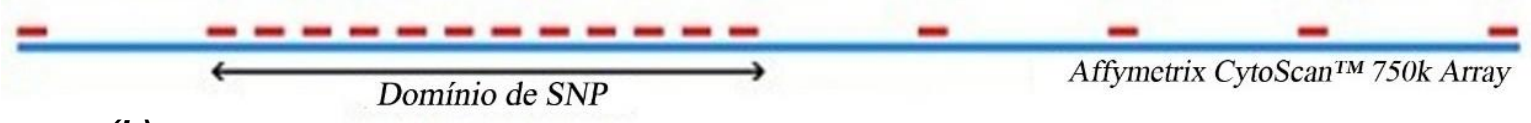

(b)

Figura 3. (a) Nível de organização e visualização da reação de hibridação com os oligonucleotídeos em microarranjos no GeneChip ${ }^{\circledR}$ da plataforma CytoScan ${ }^{\circledR} 750 K$ Array (Affymetrix, EUA). (b) Representação esquemática do nível de resolução comparando as diferenças na cobertura da densidade de sondas nas diferentes regiões do genoma no chip CytoScan ${ }^{\circledR} 750$ k Array (Affymetrix, EUA). 
aumentando a precisão, confiabilidade e reprodutibilidade dos resultados. Sendo assim os GeneChip $^{\circledR}$ contêm centenas de milhares de sondas de DNA individualizadas, que no seu conjunto representam todo o genoma humano incluindo variações intragênicas correlacionadas.

O sistema todo inclui os oligonucleotídeos pré-arranjados em GeneChip ${ }^{\circledast}$, conjunto de 38 reagentes diferentes, equipamentos para hibridação, lavagem, coloração, leitura e visualização dos microarranjos, e programa computacional necessário para a identificação dos SNPs e das CNVs. Um diferencial desta plataforma, é que é possível analisar tanto o número de cópias alelo-específicas quanto os genótipos de SNPs. Além disso, ela confirma independentemente as CNVs com informações alélicas de SNPs. Tudo isso garante que tenha uma das mais abrangentes e relevantes coberturas de genes constitucionais em um único array. Assim, há uma cobertura de $100 \%$ dos genes constitucionais do ClinGen, cobrindo ainda, cerca de $83 \%$ dos genes do OMIM e $80 \%$ dos mais de 36 mil genes do RefSeq (NCBI Reference Sequence Database). Uma esquematização de cada um dos passos envolvidos na técnica está representada na Figura 4.

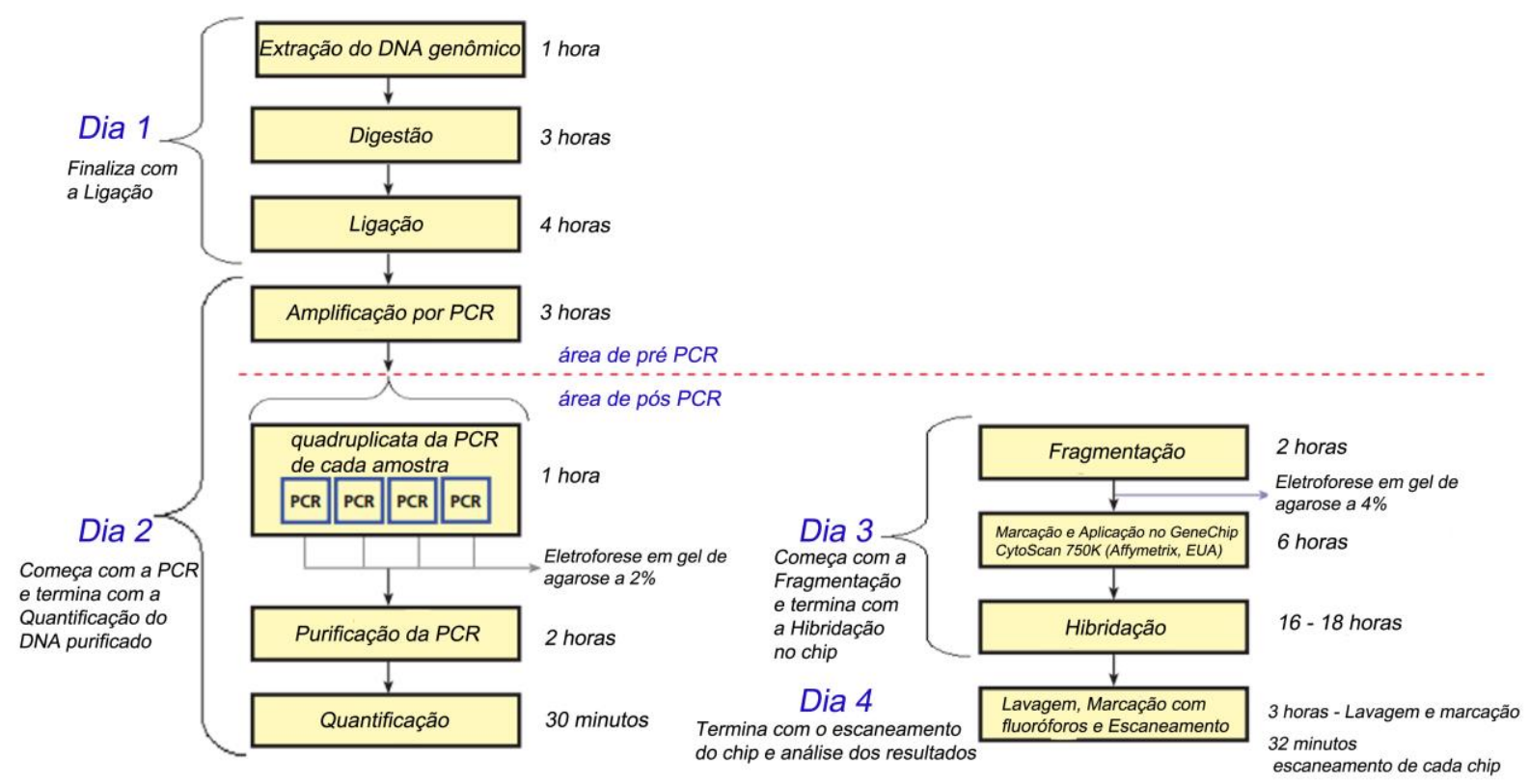

Figura 4. Protocolo da plataforma Affymetrix ${ }^{\circledR}$ CytoScan $^{\circledR} 750 \mathrm{k}$ Array, com o tempo aproximado para a realização de cada etapa. 


\subsubsection{Preparação do DNA genômico}

Seguindo os padrões recomendados pelo fabricante quanto à estrutura de trabalho, condições e materiais utilizados foi dada sequência ao protocolo do SNP array para a análise das amostras, que tem início com a normalização da concentração das amostras para $50 \mathrm{ng} / \mu \mathrm{L}$ de DNA diluído em Low EDTA TE buffer (Affymetrix, EUA). Utilizou-se o protocolo estabelecido para um sistema de 16 reações contando com 14 amostras, um controle positivo (fornecido pela Affymetrix) e um controle negativo.

\subsubsection{Digestão com Nsp I, ligação de adaptadores e amplificação}

Os DNAs dos pacientes e controles foram submetidos à digestão em sítios específicos com a enzima Nsp I (Affymetrix, EUA) para a obtenção de fragmentos de DNA de tamanhos variados e posterior ligação de adaptadores com a T4 DNA Ligase (Affymetrix, EUA), preparando a amostra para a amplificação através da reação da PCR.

Foi utilizada uma mistura de $5 \mu \mathrm{L}$ de DNA $(50 \mathrm{ng} / \mu \mathrm{L}), 11,55 \mu \mathrm{L}$ de água ultrapura, 2,00 $\mu \mathrm{L}$ de tampão da $N s p$ I (10X), 0,20 $\mu \mathrm{L}$ de albumina bovina sérica

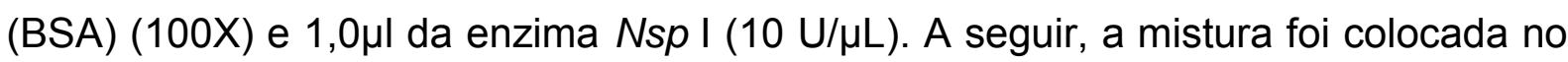
termociclador Veriti $^{\circledR}$ (Life Technologies, EUA) por duas horas a $37^{\circ} \mathrm{C}$ e 20 minutos a $65^{\circ} \mathrm{C}$. Os produtos da digestão foram armazenados a $-20^{\circ} \mathrm{C}$ até o próximo passo.

A seguir, foi realizada a ligação dos fragmentos de DNA aos adaptadores específicos, com a mistura de 0,75 $\mu \mathrm{L}$ de adaptador $N s p$ I $(50 \mu \mathrm{M}), 2,50 \mu \mathrm{L}$ de tampão da T4 DNA Ligase (10X) e 2,00 $\mu \mathrm{L}$ da enzima T4 DNA Ligase (400 U/ $\mu \mathrm{L})$. A mistura foi colocada no termociclador por três horas a $16^{\circ} \mathrm{C}$ e 20 minutos a $70^{\circ} \mathrm{C}$. Os produtos da reação de ligação foram diluídos com $75 \mu \mathrm{L}$ de água e foram armazenados a $-20^{\circ} \mathrm{C}$ até o próximo passo.

Foram feitas quadruplicatas das reações da PCR de cada amostra para aumentar a quantidade do DNA genômico. Os fragmentos de DNA ligados a adaptadores Nsp I foram submetidos à reação da PCR com a utilização de $39,5 \mu \mathrm{L}$ de água ultrapura, 10,0 $\mu \mathrm{L}$ de tampão da TITANIUM ${ }^{T M}$ Taq (10X), 20,0 $\mu \mathrm{L}$ de reagente GC-Melt, 14,0 $\mu \mathrm{L}$ de mistura de dNTP's $(2,5 \mathrm{mM}$ cada), 4,5 $\mu \mathrm{L}$ do iniciador PCR Primer $002(100 \mu \mathrm{M})$ (Affymetrix, EUA) e 2,0 $\mu \mathrm{L}$ da enzima TITANIUM ${ }^{\text {TM }}$ Taq 
DNA polimerase (50X) (Clontech, EUA). As quadruplicatas, foram colocadas no termociclador onde as reações tinham 1 ciclo de incubação a $94^{\circ} \mathrm{C}$ (3 minutos), 30

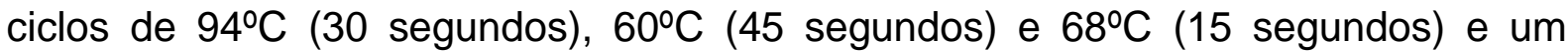
último ciclo de $68^{\circ} \mathrm{C}$ (7 minutos).

O produto da PCR foi visualizado em gel de agarose $2 \%$ em TBE $1 \mathrm{X}$ corado com brometo de etídio $(5 \mathrm{mg} / \mathrm{mL})$ submetido a um campo elétrico com voltagem constante de $10 \mathrm{~V} / \mathrm{cm}$, por $1 \mathrm{~h}$. Os fragmentos devem se apresentar como um arraste entre 150 a 2000 pb, confirmando o sucesso da digestão, ligação e PCR, permitindo a sequência do protocolo. A imagem foi capturada utilizando o sistema de vídeodocumentação ImageMaster ${ }^{\circledR}$ VDS - Video-documentation System (Pharmacia Biotech, EUA). Os produtos das PCRs foram armazenados a $-20^{\circ} \mathrm{C}$ até o próximo passo.

\subsubsection{Mistura dos produtos das PCRs, purificação e quantificação}

Os produtos das PCRs das quadruplicatas de cada amostra foram reunidos em um único tubo (volume final $397 \mu \mathrm{L}$ ) e os fragmentos de DNA foram capturados com o uso de esferas magnéticas (Affymetrix, EUA). Após incubação e centrifugação, as esferas magnéticas contendo fragmentos de DNA aderidos a sua superfície foram selecionadas por força magnética na MagnaRack ${ }^{\text {TM }}$ (Life Technologies, EUA), lavadas com tampão da purificação (Affymetrix, EUA) e, finalmente, os DNAs eluidos em tampão de eluição (Affymetrix, EUA) para um volume final de $47 \mu \mathrm{L}$. O material foi quantificado no espectrofotômetro Nanodrop ${ }^{\circledR} 2000$ (Thermo Scientific, EUA). Para continuação do protocolo, cada amostra deve apresentar valores de concentração de DNA $\geq 3.0 \mu \mathrm{g} / \mu \mathrm{L}$. Os produtos das PCRs purificados foram armazenados a $-20^{\circ} \mathrm{C}$ até o próximo passo.

\subsubsection{Fragmentação dos produtos das PCRs}

Os produtos das PCRs inicialmente foram misturados com $10 \mu \mathrm{L}$ do mix de fragmentação que é cuidadosamente preparado com $123.5 \mu \mathrm{L}$ de água ultrapura, 158,4 $\mu \mathrm{L}$ de tampão de fragmentação 10x (Affymetrix, EUA) e 5,8 $\mu \mathrm{L}$ do reagente de fragmentação $(2,5 \mathrm{U} / \mu \mathrm{L})$. A mistura foi colocada no termociclador por 35 minutos a $37^{\circ} \mathrm{C}$ e 15 minutos a $95^{\circ} \mathrm{C}$. A fragmentação (volume final: $55 \mu \mathrm{L}$ ) foi observada pela 
presença de um arraste entre 25 e 125 pb em eletroforese em gel de agarose 4\% em TBE $1 X$ corado com brometo de etídio $(5 \mathrm{mg} / \mathrm{mL})$ submetido a um campo elétrico com voltagem constante de $10 \mathrm{~V} / \mathrm{cm}$, por $1 \mathrm{~h}$. A imagem foi capturada utilizando 0 sistema de vídeo-documentação. Os fragmentos obtidos foram armazenados a $20^{\circ} \mathrm{C}$ até o próximo passo.

\subsubsection{Marcação do DNA fragmentado com biotina}

A marcação das amostras foi realizada com a mistura de $51 \mu \mathrm{L}$ do DNA fragmentado e 19,5 $\mathrm{L}$ da mistura de marcação formada por 14,0 $\mu \mathrm{L}$ de tampão Terminal deoxynucleotidyl Transferase (5X), 2,0 $\mu \mathrm{L}$ de reagente de marcação de DNA $30 \mathrm{mM}$ (biotina) e 3,5 $\mu \mathrm{L}$ da enzima TdT (30 U/ $\mu \mathrm{l})$. A mistura foi colocada no termociclador por quatro horas a $37^{\circ} \mathrm{C}$ e 15 minutos a 95으. $\mathrm{O}$ DNA marcado com biotina foi armazenado a $-20^{\circ} \mathrm{C}$ até o próximo passo.

\subsubsection{Hibridação}

Primeiramente foi preparada a mistura de hibridação com os tampões de hibridação parte $1(165,0 \mu \mathrm{L})$, parte $2(15,0 \mu \mathrm{L})$, parte $3(7,0 \mu \mathrm{L})$ e parte $4(1,0 \mu \mathrm{L})$, mais 2,0 $\mathrm{LL}$ de OCR (Oligo Control Reagent, Affymetrix, EUA). Em seguida foi realizada a mistura de $70,5 \mu \mathrm{L}$ de DNA biotinilado e $190 \mu \mathrm{L}$ da mistura de hibridação. Esta mistura foi aquecida no termociclador a $95^{\circ} \mathrm{C}$ por 10 minutos e resfriada a $49^{\circ} \mathrm{C}$ até o próximo passo. Ainda no termociclador, $200 \mu \mathrm{l}$ da mistura desnaturada foi depositada imediatamente em cada um dos GeneChip ${ }^{\circledR}$ com os oligonucleotídeos pré-arranjados. Os GeneChip ${ }^{\circledR}$ com o DNA são incubados em forno de hibridação (modelo Hybridization Oven 645, Affymetrix, EUA) a 50 durante 16 a 18 horas a 60 rpm. A figura 5 representa de forma esquemática as etapas de preparação da amostra até a hibridação no chip. 


\subsubsection{Lavagens dos GeneChip® e marcação com fluoróforos}

A lavagem e marcação dos GeneChip $^{\circledR}$ foi realizada na estação automatizada Fluidics Station 450 (Affymetrix, EUA) que foi previamente abastecida com os tampões de lavagem A e lavagem B (Affymetrix, EUA) mais água ultrapura. Foram preparados também os tubos separados contendo os tampões de marcação 1 (500 $\mu \mathrm{L}), 2(500 \mu \mathrm{L})$ e $800 \mu \mathrm{L}$ de holding buffer (Affymetrix, EUA) que apresentam em suas formulações os elementos essenciais (conjugado ficoeritrina-estreptavidina e anticorpo anti-estreptavidina biotinilado) para a formação da fluorescência durante a leitura dos GeneChip ${ }^{\circledR}$ com o laser.

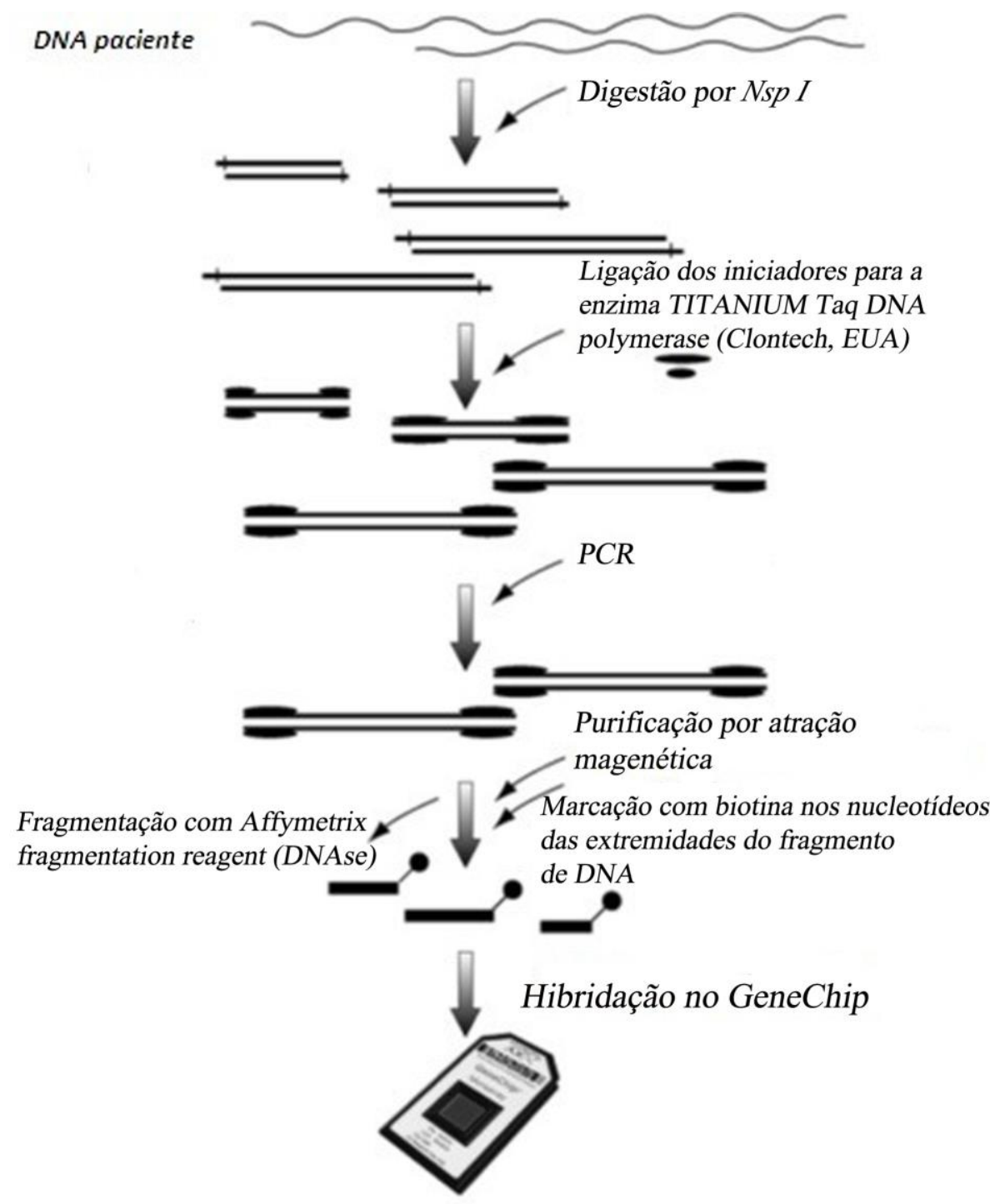

Figura 5: Etapas envolvidas na busca por alterações cromossômicas pela técnica de CMA utilizando o sistema de hibridação da plataforma CytoScan 750k Array (Affymetrix, EUA). 
Em seguida, os GeneChip ${ }^{\circledR}$ são retirados do forno de hibridação e, imediatamente, colocados (oito por vez) na estação fluídica onde as sequências de lavagens e marcações por fluoróforos dos microarranjos são automatizadas sob controle do software Affymetrix GeneChip ${ }^{\circledR}$ Command Console $^{\circledR}$ (AGCC) versão 4.1.2 (Affymetrix, EUA).

\subsubsection{Escaneamento dos GeneChipß, captação de imagens e análise no software Chromosome Analysis Suite 3.0 (Affymetrix, EUA)}

Os chips com microarranjos foram colocados no GeneChip ${ }^{\circledR}$ Scanner $30007 \mathrm{G}$ (Affymetrix, EUA), gerenciado pelo programa AGCC. A imagem dessa leitura pode ser observada com o programa de visualização Affymetrix GeneChip Viewer (Affymetrix, EUA), onde também se podem verificar os controles positivos do sistema de forma a se comprovar que as condições de hibridação do microarranjo foram adequadas.

Após estes procedimentos, utilizando o software de análise Chromosome Analysis Suite (ChAS) versão 3.0 (Affymetrix, EUA) é possível visualizar e analisar as alterações cromossômicas (duplicações, deleções, CNVs, mosaicismo, perda de heterozigosidade) ao longo do genoma de cada amostra. O programa é oferecido gratuitamente no sítio do fabricante (www.Affymetrix.com) e trabalha com a interface do Microsoft Windows 7 Professiona ${ }^{\circledR}$ e Windows $8.1^{\circledR}$. Ele permite converter e normalizar os dados brutos obtidos dos diferentes níveis de fluorescência em cada sonda hibridada no chip (formatados pelo GeneChip Viewer) em arquivos ".CEL". Estes, por sua vez, são transformados pelo ChAS em arquivos ".CYCHP”, através da combinação de algoritmos específicos, com os dados das fluorescências de cada sonda, representando cada região do genoma humano, disponíveis no banco de dados NetAff ${ }^{\circledR}$ Genomic Annotation file NA33.1 (hg19). Este sistema de comparação de hibridação sustenta a plataforma $C y t o S c a n^{\circledR}$ e contêm informações atualizadas dos bancos de dados genômicos Database of Genomic Variants (DGV), OMIM e RefSeq.

Com isso, é possível visualizar pelo ChAS os dados genômicos resultantes da análise da hibridação sumarizados em forma de tabelas, gráficos e cariótipo do 
paciente juntamente com os dados (arquivos ".CNCHP") da plataforma ao qual são comparados. O software permite, ainda, criar e customizar parâmetros e regiões para uma análise específica, aplicar filtros para todo o genoma ou regiões de interesse específico para remover informações não relevantes, realizar análises comparativas entre diferentes amostras, além de acessar os principais bancos de dados externos (NCBI, UCSC Genome Browser, Ensembl, OMIM). Além disso, os resultados podem ser comparados com as alterações genômicas e fenotípicas disponíveis no DECIPHER. Com todo este conjunto de ferramentas da bioinformática disponíveis, a habilidade do pesquisador é que vai permitir buscar e compreender as alterações de relevância clínica dentre a grande quantidade de dados, normalmente, gerados pelo array. Todo este procedimento leva de 4 a 5 dias para ser concluído. Uma esquematização destes últimos passos está representada na Figura 6.

Para a análise dos dados gerados pela hibridação do genoma dos pacientes foram estabelecidos filtros de 30 sondas (aproximadamente $120 \mathrm{~Kb}$ ), para detectar duplicações cromossômicas, e 15 sondas (aproximadamente $60 \mathrm{~Kb}$ ) para detectar as deleções (inclusive em mosaico), seguindo recomendações do fabricante. Os dados genômicos só foram analisados após terem passado pelos controles de qualidade do software. Todas as alterações no número de cópias registradas pela filtragem foram rigorosamente analisadas e os ruídos (alterações encontradas em regiões cobertas por menos de $75 \%$ de sondas) foram descartados deste estudo.

A plataforma CytoScan ${ }^{\circledR}$ Array da Affymetrix utilizada neste estudo difere das metodologias utilizadas na primeira e segunda geração de arrays com aplicação na Genética Molecular. O conceito experimental envolvia a comparação do padrão de hibridação da amostra estudada com outra amostra controle. Naqueles sistemas, o padrão da fluorescência resultava da hibridação competitiva entre as amostras, o que refletia as diferenças quantitativas (duplicações ou deleções) ao longo do genoma. No caso da plataforma utilizada aqui, a comparação ocorre entre os dados da fluorescência da amostra testada no GeneChip ${ }^{\circledR}$ com aqueles depositados no banco de dados NetAff ${ }^{\circledR}$ Genomic Annotation file NA33.1 (hg19) desenvolvido para a plataforma. Este por sua vez contêm os dados dos mais de 750 mil marcadores genéticos (aproximadamente 500 mil para CNVs somados aos cerca de 250 mil para SNPs) obtidos da análise de 96 indivíduos normais e 284 linhagens celulares 


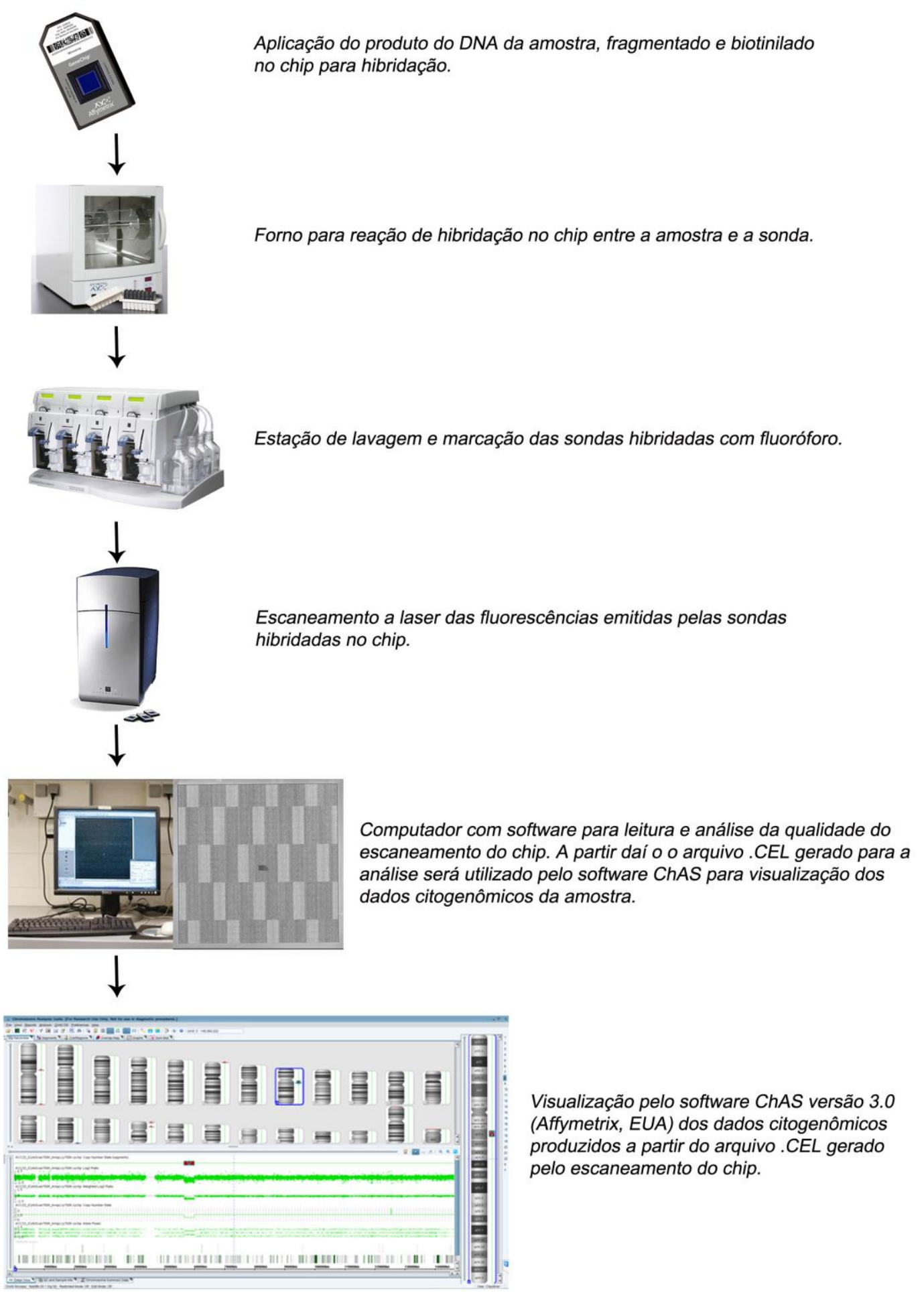

Figura 6. Esquema geral das etapas e dos equipamentos utilizados para a reação de CMA envolvendo as etapas da hibridação, lavagem, marcação, escaneamento, leitura e análise dos dados do GeneChip ${ }^{\circledR}$ da plataforma CytoScan ${ }^{\circledR} 750 \mathrm{~K}$ Array (Affymetrix, EUA). 
referenciadas do HapMap. O desempenho robusto da plataforma CytoScan ${ }^{\circledR}$ Array permite uma ampla cobertura do genoma e confiabilidade nos dados obtidos.

Após todas estas análises, a CNV encontrada pode ser classificada como patogênica, ou possivelmente patogênica, ou benigna ou de significado clínico desconhecido. Foram coletadas informações como: tipo (deleção ou duplicação), extensão da CNV, número de cópias envolvidas, cromossomo e banda cromossômica, tamanho e número de marcadores e genes envolvidos nas alterações.

Para investigar a presença de microrrearranjos cromossômicos que possam ter correlação etiológica com a ACC e outras malformações associadas, somente consideramos para análise os resultados obtidos que apresentaram valores dos indicadores de qualidade do experimento próximos ou de acordo com o que é indicado pelo fabricante para uma análise consistente e confiável dos dados.

Os valores dos controles de qualidade MAPD (Median Absolute Pairwise Differences) e SNPQC (Single Nucleotide Polymorphism quality control) representam, respectivamente, uma medida global da variação de todas as sondas do array ao longo do genoma, através da distribuição das mudanças, em uma escala logarítimica, entre sondas adjacentes polimórficas (SNP) e não polimórficas (CN) e uma medida do nível de qualidade da genotipagem dos alelos nos dados do array sendo obtido a partir da perspectiva das sondas polimórficas (SNP). Outro controle de qualidade utilizado da reação é o Waviness-SD (Waviness standard deviation), que representa a medida global da variação das sondas do array que são insensíveis às variações de pequena amplitude e focadas nas variações de longa amplitude.

Os valores indicados pela Affymetrix devem ser iguais ou superiores a 15 no $S N P Q C$, e iguais e inferiores a 0,25 no MAPD e 0,12 no Waviness $S D$. Esses valores são fornecidos após análise pelo ChAS 3.0 dos dados fornecidos pelo escaneamento do chip hibridado. No entanto, para os propósitos deste estudo e utilizando a plataforma $750 \mathrm{k}$, foram considerados de acordo com os parâmetros recomendados pelo FDA (United States Food and Drug Administration) para este tipo de array e com propósitos de investigação de alterações genômicas em humanos (disponível em http://www.accessdata.fda.gov/cdrh_docs/reviews/K130313.pdf), os resultados que apresentaram valores de SNPQC iguais ou superiores a 12 e os resultados de 
MAPD e Waviness-SD iguais ou inferiores a 0,25 e 0,12, respectivamente, contudo sem perder a consistência e a confiabilidade das análises. Vale lembrar, utilizou-se no ChAS um filtro de seleção envolvendo, no mínimo, 30 sondas consecutivas para as duplicações e 15 sondas consecutivas para os fragmentos deletados (Figura 7).

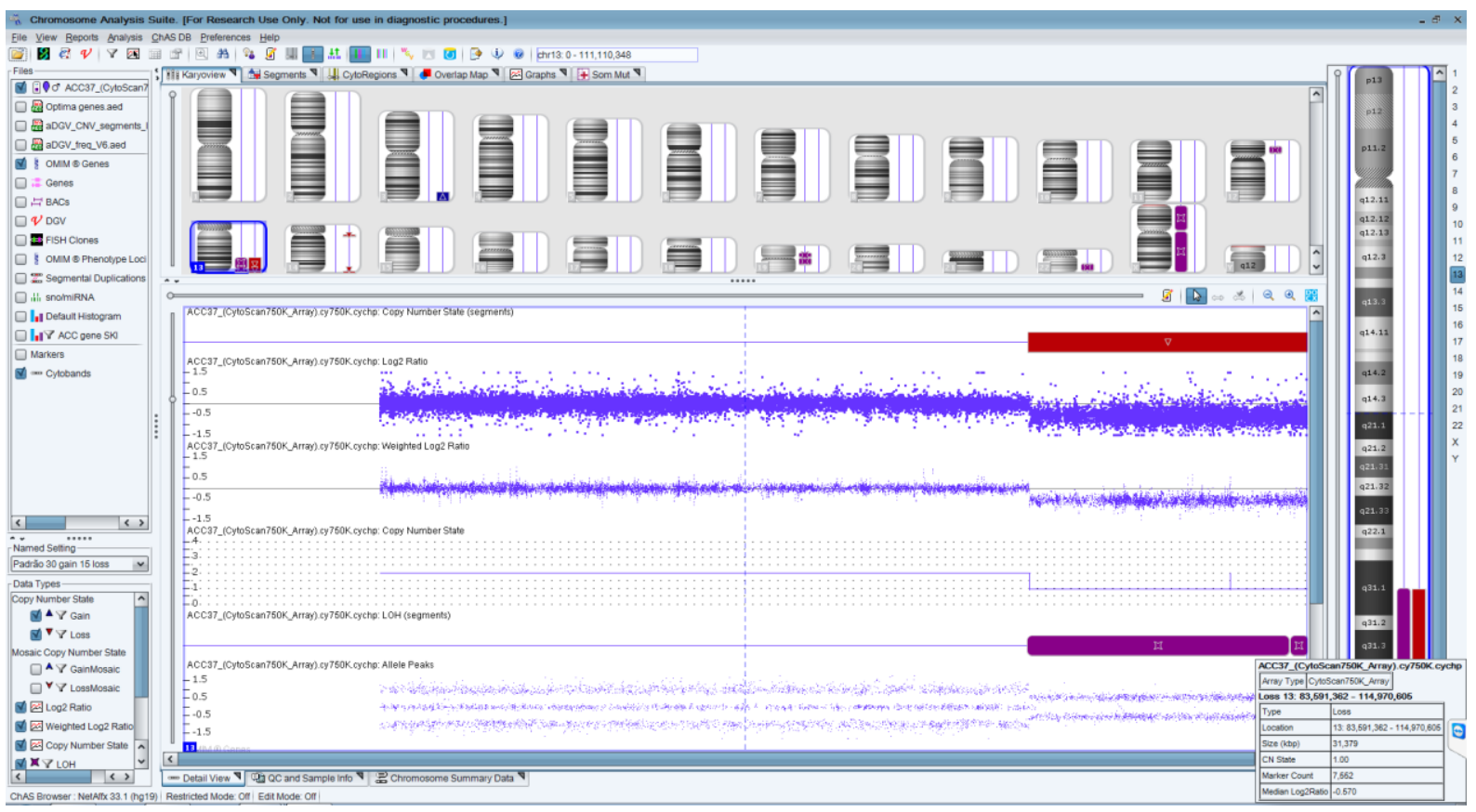

Figura 7: Vista geral da tela do software de análises ChAS v.3.0 (Affymetrix, EUA) após o processamento dos dados da CMA de uma amostra, evidenciando na parte superior o carioview, com os cromossomos humanos enumerados e com as citobandas correspondentes, na parte inferior a representação das sondas hibridadas no chip. À esquerda, as coordenadas e os parâmetros utlizados para a análise da amostra. À direita, a representação da estrutura detalhada do cromossomo selecionado para análise, com os dados citogenômicos da alteração encontrada no DNA do paciente evidenciados na parte inferior. As CNVs que envolvem ganho numérico de segmentos cromossomais são representadas por barras de cor azul e as que envolvem perda numérica estão registradas por barras de cor vermelha. Por se tratar de um SNP-array, é possível detectar outras alterações cromossômicas como a perda de heterozigose $(\mathrm{LOH})$, registradas com barras de cor violeta.

Neste estudo, as CNVs encontradas em cada paciente foram comparadas com as CNVs de mais de 2.800 amostras controles normais depositadas no banco de dados de grupos controle fornecido pelo fabricante para a plataforma do ChAS, somando-se à comparação com as informações fornecidas pelos principais bancos de dados públicos, como OMIM, RefSeq, DECIPHER e DGV. Assim é possível pesquisar se as alterações encontradas através do exame de CMA, somadas às características clínicas, foram descritas (ou não) em qualquer parte do mundo, e 
ainda, se são síndromes bem validadas e conhecidas (ou não). Com as coordenadas genômicas da CNV fornecidas pela CMA é possível no UCSC Genome Browser, por exemplo, confirmar o tamanho da alteração, os genes envolvidos, além de permitir acesso aos casos semelhantes descritos ou no banco de dado de alterações normais (DGV) ou nos bancos que registram as CNVs patogênicas (ClinGen, DECIPHER, CAGdb). Com isso, torna-se possível verificar informações a respeito do fenótipo de outros indivíduos com a mesma alteração ou alteração semelhante, se a alteração já foi descrita como patogênica ou como variante benigna, a relação dos genes afetados pela CNV com doenças genéticas conhecidas, e se a CNV é objeto de interesse em outros grupos de pesquisa. Consideram-se ainda, nesta análise, as informações clínicas e fenotípicas do paciente.

Após esta etapa, pesquisam-se dados na literatura a respeito dos genes ou das regiões genômicas envolvidas para, se possível, encontrar a relação causal entre a função dos mesmos com o tipo de variação encontrada e o fenótipo clínico verificado. Para isso, verificam-se dados disponíveis sobre sensibilidade à dosagem (superexpressão ou haploinsuficiência) do gene, sobre as mutações já descritas e seu envolvimento com patologias humanas. Caso as alterações não possuam algum caráter patogênico associado então a solução é buscar na literatura informações sobre a região e/ou genes envolvidos. E mais, para não fugir do escopo deste estudo, os resultados referentes somente às LOHs não foram considerados nas análises, uma vez que seria necessária a realização de outros testes moleculares, tais como sequenciamento gênico, para confirmação das hipóteses que, geralmente, estão relacionadas com mutação pontual recessiva em algum gene crítico da região homozigota. 


\section{RESULTADOS E DISCUSSÃO}

\subsection{CARACTERIZAÇÃO DA POPULAÇÃO ESTUDADA E ANÁLISE DAS ALTERAÇÕES CLÍNICAS DOS PACIENTES}

Neste estudo, foram investigadas por CMA 54 amostras referentes aos pacientes que concordaram em participar da pesquisa e que foram atendidos pelos Serviços de Genética do NUGEN da SES-DF e do HUB na UnB, dos quais $51 \%$ eram do sexo masculino e $49 \%$ do sexo feminino. A maioria dos casos $(78 \%)$ têm idade $\leq 5$ anos, e são provenientes de cidades do Distrito Federal e Entorno que abrange os estados de Goiás e Minas Gerais, além de alguns casos provenientes dos estados do Maranhão, Bahia e Paraíba.

O principal critério clínico para solicitação do exame de CMA foi que apresentassem quadro de ACC completa ou parcial (DCC ou Hipoplasia do CC) associado com ADNPM e/ou DI, sem caracterização de síndrome genética definida e/ou com alguma malformação estrutural. Nestes 54 pacientes, a ACC completa estava presente em $44 \%$ dos pacientes enquanto a DCC e a Hipoplasia do CC em $31 \%$ e $24 \%$, respectivamente. O cariótipo normal foi confirmado para $72 \%$ do total de casos. Dentre os diversos achados clínicos relatados, os mais prevalentes foram dismorfias faciais (96\%), ADNPM e/ou DI (80\%) e anomalias oftalmológicas (78\%) (Tabela 1).

Cada vez mais a prática clínica se beneficia dos resultados oferecidos pelos avanços da CMA que, por sua vez, possui aplicação cada vez mais ampla nas diversas áreas que envolvem o diagnóstico médico. Neste contexto, tornam-se importantes os progressos alcançados no campo da investigação dos rearranjos submicroscópicos, visto que estas alterações podem estar envolvidas na complexa etiologia das malformações estruturais e ADNPM (140).

A adoção da CMA, seja CGH array ou SNP-array, como primeira estratégia de investigação de alterações cromossômicas submicroscópicas ganhou força nos últimos anos por conta da maior eficiência e dos benefícios trazidos comparados às técnicas tradicionais $(28,29)$. Como a CMA não requer conhecimento prévio de regiões específicas dos cromossomos, então tem a vantagem de poder ser utilizada no rastreamento por rearranjos cromossômicos desconhecidos $(28,141)$. 
Tabela 1 - Principais alterações clínicas descritas nos pacientes estudados.

\begin{tabular}{|c|c|c|}
\hline Alteração clínica & № de indivíduos & Porcentagem \\
\hline ACC completa & 24 & $44 \%$ \\
\hline DCC* & 17 & $31 \%$ \\
\hline Hipoplasia do CC* & 13 & $24 \%$ \\
\hline ADNPM* $^{*}$ & 34 & $63 \%$ \\
\hline DI $^{*}$ & 10 & $18 \%$ \\
\hline Convulsões & 16 & $29 \%$ \\
\hline Dificuldade na fala & 18 & $33 \%$ \\
\hline Dificuldade motora & 26 & $48 \%$ \\
\hline Dificuldade no aprendizado & 25 & $46 \%$ \\
\hline TEA $^{*}$ & 3 & $5 \%$ \\
\hline Dismorfias faciais & 52 & $96 \%$ \\
\hline Anomalias oftalmológicas & 42 & $77 \%$ \\
\hline Anomalias auditivas & 10 & $18 \%$ \\
\hline Anomalias Cardiorespiratórias & 16 & $29 \%$ \\
\hline Anomalias Genitourinárias & 12 & $22 \%$ \\
\hline $\begin{array}{r}\text { Dismorfias de membros e/ou } \\
\text { tronco }\end{array}$ & 42 & $77 \%$ \\
\hline
\end{tabular}

A taxa de detecção da CMA depende da plataforma utilizada, da cobertura e da densidade das sondas, do processo de seleção e do espectro fenotípico dos pacientes analisados. Neste sentido, estudos nos últimos anos apresentaram diferentes taxas de diagnóstico com valores variando entre $7 \%$ a $20 \%(28,31,32)$. A adoção da CMA como primeiro exame no diagnóstico clínico de indivíduos com ADNPM ou anomalias congênitas ganhou força após a publicação de um estudo consenso onde se estabeleceu que a análise do cariótipo por banda $G$ deveria ser reservada para pacientes com síndromes cromossômicas óbvias, com histórico familiar de rearranjos cromossômicos ou de múltiplos abortamentos. Além disso, a 
análise do cariótipo pós-CMA possibilitaria verificar a existência de translocações balanceadas que estaria presente em $0,3 \%$ dos pacientes (29).

Dificuldades na implantação desta estratégia incluem o complexo desenvolvimento dos arrays e dos softwares de análises, a integração à rotina dos diagnósticos clínicos, a padronização, os níveis de qualidade das diferentes plataformas, a possibilidade de resultados falsos positivos, além do suporte clínico e laboratorial necessários para interpretação correta dos resultados, e constituem o principal desafio para a maioria dos serviços públicos de saúde. Felizmente, a maior diversidade destes exames e o maior acesso dos pacientes e profissionais da saúde à estas novas tecnologias, permitiram diminuir os custos e viabilizar a triagem de pacientes nos centros de referência em saúde (141).

Apesar de todos os esforços, aproximadamente $60 \%$ dos casos de DI permanecem com a etiologia genética desconhecida (16). Aberrações citogenéticas visíveis ao microscópio (incluindo aneuploidias, deleções grosseiras, inversões e rearranjos) estão presentes em $15 \%$ dos casos (7), CNVs detectadas por CMA explicam outros 15\% (27), mutações de ponto e pequenas inserções e deleções (indels) são encontradas em mais de 90 formas ligadas ao $\mathrm{X}$, as quais somam aproximadamente $10 \%$ dos casos (12). Defeitos epigenéticos envolvendo a metilação foram identificados em alguns casos raros, e são conhecidos mais de 100 genes autossômicos e ligados ao X envolvidos nas formas não sindrômicas de DI $(12,142)$. Uma das muitas razões que dificultam esse processo de investigação da DI está na sua grande heterogeneidade genética e fenotípica.

Muitos casos de DI ocorrem por causa de mutações de novo, sejam elas CNVs ou mutações de ponto em único gene, conforme sugerido pelos estudos de Vissers e colaboradores (6) e Need e colaboradores (143). No entanto para os casos de DI idiopática familiar e, em algumas síndromes associadas com CNVs (ex: Síndrome de Aicardi - MIM \#304050), a complexidade genética aumenta e ainda não foram estabelecidos estudos consensos que explicam por completo os fenômenos envolvendo padrões de segregação não mendelianos, expressividade variável e penetrância incompleta $(144,145)$.

Siggberg e colaboradores (106) verificaram que CNVs com relevância clínica estão presentes em $18 \%$ dos indivíduos com DI e/ou dismorfias associadas, incluindo portadores de Síndromes que são caracterizadas pela ACC. Recentemente, em um estudo realizado no Centro-Oeste do Brasil com pacientes 
que tinham DI e cariótipo normal, verificaram por meio do SNP-array que 22\% das CNVs encontradas eram patogênicas, $28 \%$ aparentemente tinham patogenicidade e 50\% tinham significado clínico desconhecido (146).

A maioria das síndromes genéticas associadas com ACC possuem diversas características neurológicas e neuroanatômicas as quais servem para definir desde um quadro não sindrômico de DI mais leve até um nível onde o paciente possui DI grave com anormalidades neuroanatômicas e malformações congênitas. Dentre os sintomas clínicos compartilhados por estas síndromes genéticas com ACC incluem, em particular, anormalidades oculares e anomalias da linha média incluindo hipertelorismo, fenda lábio palatina, anomalias cardíacas congênitas, e anomalias urogenitais (34). Alguns destes aspectos clínicos também foram compartilhados pelos pacientes com anomalias do CC do presente estudo (Tabela 1). Alguns fatores podem ter contribuído para que alguns sinais clínicos tenham sido subnotificados: heterogeneidade da análise clínica das características fenotípicas dos pacientes realizada pelos médicos geneticistas, anamnese incompleta ou inadequada dos pacientes, não envolvimento de médicos (ex; neuroradiologista ou neurologista pediátrico) de outras especialidades no auxílio dos exames de neuroimagens, ausência de exames complementares disponíveis.

Embora o principal critério de inclusão do paciente no presente estudo seja ter alguma anomalia do CC acompanhado de alguma malformação (ADNPM e/ou DI, anomalias congênitas) que indicasse um quadro sindrômico para ser analisado por CMA, verificou-se que, na verdade, houve a indicação e inclusão de uma grande diversidade de alterações fenotípicas que, além da ACC presente, forma um apanhado geral dos principais critérios sugeridos na literatura para a indicação clínica de estudos por CMA e estudos da etiologia da ACC e/ou DI. Em dois estudos onde o critério de inclusão dos pacientes foi revisado por um clínico geneticista e por estudos cromossômicos, identificaram causa sindrômica ou cromossômica em 33\% (62) e $39 \%$ (45) dos casos.

Neste estudo foram contemplados os critérios indicados por Miller e colaboradores (29) para o uso da CMA como teste inicial para investigação clínica em indivíduos com deficiências do desenvolvimento ou anomalias congênitas, pois os pacientes apresentavam alterações do CC com fenótipos associados que sugeririam a presença de alterações genéticas envolvendo CNVs e/ou SNPs que não seriam detectados pelo cariótipo tradicional. 
No presente estudo, de acordo com os registros clínicos dos pacientes, as dismorfias faciais estavam presentes em $96 \%$ dos casos, seguidos por anomalias oftalmológicas e dismorfias de membros e/ou tronco com $77 \%$ cada (Tabela 1). Comparativamente, em outro estudo constatou-se que as principais indicações clínicas para realização do exame de CMA, em indivíduos que não foram diagnosticados com uma síndrome definida, são ADNPM seguido por comprometimento intelectual e pela presença de dismorfias (147).

Um número significativo de pacientes pode apresentar CNVs de significado desconhecido ao diagnóstico, por isso que quanto maior for a CNV e o número de genes nela envolvidos, mais provável que seja a causa direta da doença (29). Outro ponto importante é que, desconsiderando algumas exceções, deleções são muito mais impactantes no fenótipo do que as duplicações (29). Por outro lado, CNVs herdadas de pais fenotipicamente normais são menos prováveis de serem a causa dos sintomas clínicos apresentados do que uma CNV de novo. E mais, CNVs de grande tamanho podem, ocasionalmente, serem benignas (148) e CNVs herdadas de pais não afetados podem estar associadas com penetrância incompleta ou expressividade variável, causando alterações patológicas no probando, mas não no genitor (149).

Considerando-se todos os 54 pacientes analisados, verifica-se que a taxa de diagnóstico de CNVs patogênicas ou potencialmente patogênicas por CMA, na presença de anomalia no CC, foi de $24 \%$ (13). A Tabela 2 mostra a relação das alterações clínicas apresentadas pelos pacientes que obtiveram diagnósticos favoráveis para a anomalia do CC. Os achados clínicos que obtiveram maior taxa de diagnóstico são ACC parcial (41\%), DI (30\%), dificuldade no aprendizado e anomalias oftalmológicas com $28 \%$ cada e dificuldades na fala com $27 \%$.

A maioria dos casos que envolvem ACC possuem fatores genéticos envolvidos (40). Estudos já reportaram que $30-45 \%$ dos casos de ACC possuem causas identificáveis e que, aproximadamente, $10 \%$ possuem anomalias cromossômicas e os outros $20-35 \%$ possuem síndromes genéticas conhecidas. Entretanto, se forem considerados apenas os casos com ACC completa a quantidade de pacientes com síndromes conhecidas diminui para $10-15 \%$ e, então, $75 \%$ dos casos não possuem uma causa conhecida $(34,40,62)$. 
Tabela 2 - Taxa de diagnóstico da CMA por alteração fenotípica dos pacientes com anomalias do CC e outras malformações associadas.

\begin{tabular}{|c|c|c|c|}
\hline Alterações clínicas* & $\begin{array}{c}\text { № de } \\
\text { pacientes }\end{array}$ & $\begin{array}{c}\text { № de pacientes com CNV } \\
\text { patogênica ou } \\
\text { potencialmente patogênica }\end{array}$ & $\begin{array}{c}\text { Taxa de } \\
\text { diagnóstico } \\
(\%) \\
\end{array}$ \\
\hline ACC completa & $24(44 \%)$ & 4 & 16 \\
\hline DCC* & $17(31 \%)$ & 7 & 41 \\
\hline Hipoplasia do CC* & $13(24 \%)$ & 2 & 15 \\
\hline ADNPM $^{*}$ & $34(63 \%)$ & 6 & 17 \\
\hline $\mathrm{DI}^{*}$ & $10(18 \%)$ & 3 & 30 \\
\hline Convulsões & $16(29 \%)$ & 3 & 18 \\
\hline Dificuldade na fala & $18(33 \%)$ & 5 & 27 \\
\hline $\begin{array}{r}\text { Dificuldade } \\
\text { motora }\end{array}$ & $26(48 \%)$ & 6 & 23 \\
\hline $\begin{array}{r}\text { Dificuldade no } \\
\text { aprendizado }\end{array}$ & $25(46 \%)$ & 7 & 28 \\
\hline TEA $^{*}$ & $3(5 \%)$ & 0 & 0 \\
\hline Dismorfias faciais & $52(96 \%)$ & 13 & 25 \\
\hline $\begin{array}{r}\text { Anomalias } \\
\text { oftalmológicas }\end{array}$ & $42(77 \%)$ & 12 & 28 \\
\hline $\begin{array}{r}\text { Anomalias } \\
\text { auditivas }\end{array}$ & $10(18 \%)$ & 1 & 10 \\
\hline $\begin{array}{r}\text { Anomalias } \\
\text { Cardiorespiratórias }\end{array}$ & $16(29 \%)$ & 3 & 18 \\
\hline $\begin{array}{r}\text { Anomalias } \\
\text { Genitourinárias }\end{array}$ & $12(22 \%)$ & 2 & 16 \\
\hline $\begin{array}{r}\text { Dismorfias de membros } \\
\text { e/ou tronco }\end{array}$ & $42(77 \%)$ & 11 & 26 \\
\hline
\end{tabular}




\subsection{ANÁLISE E CLASSIFICAÇÃO DAS CNVS ENCONTRADAS}

A CMA revelou que $68 \%$ dos indivíduos analisados apresentavam em seus genomas apenas CNVs benignas ou não causais, que são aquelas encontradas em indivíduos controles normais descritos no DGV (150). Esse valor é superior ao de pacientes com CNVs raras, uma vez que as CNVs são comuns no genoma humano. $O$ resultado da CMA nesses pacientes foi considerado normal. O restante dos pacientes (32\%) apresentou em seus respectivos CMAs pelo menos uma CNV que foi analisada quanto aos possíveis mecanismos de herança e potencial patogênico.

Realizamos a CMA nos genitores de 59\% (10) dos pacientes que tinham CNVs não descritas no DGV. Sendo assim, por meio da CMA foi possível comprovar que em $50 \%$ dos indivíduos as alterações numéricas encontradas eram de novo (Tabela 3). Somando-se a estas análises, a obtenção do resultado do cariótipo por banda $G$ dos genitores referentes a dois pacientes permitiu determinar também a origem genética da alteração encontrada no array.

Do total de indivíduos com CNVs não descritas no DGV, 64\% apresentaram somente microduplicações e/ou microdeleções que não poderiam ser detectadas pelas técnicas tradicionais de cariótipo, enquanto os outros $36 \%$ dos casos apresentaram translocações não balanceadas que são visíveis à Citogenética convencional (Tabela 4).

O rendimento observado no presente estudo é maior do que o observado em outros estudos na literatura $(56,151)$, possivelmente, em virtude do grupo de pacientes reunidos ser relativamente menor e por causa da maior resolução da plataforma utilizada aqui. Porém, ainda assim, foi suficiente para reforçar a informação de que o rendimento diagnóstico da CMA para casos de ACC, ADNPM e/ou DI, e outras malformações associadas de causa desconhecida é superior ao gerado por metodologias de citogenética convencional. A origem genética das CNVs encontradas pela CMA em cinco dos pacientes (29\%) com CNVs raras não puderam ser verificadas por motivos variados. 
Tabela 3 - Número de pacientes correlacionando com o tipo e a origem da CNV encontrada por meio da CMA.

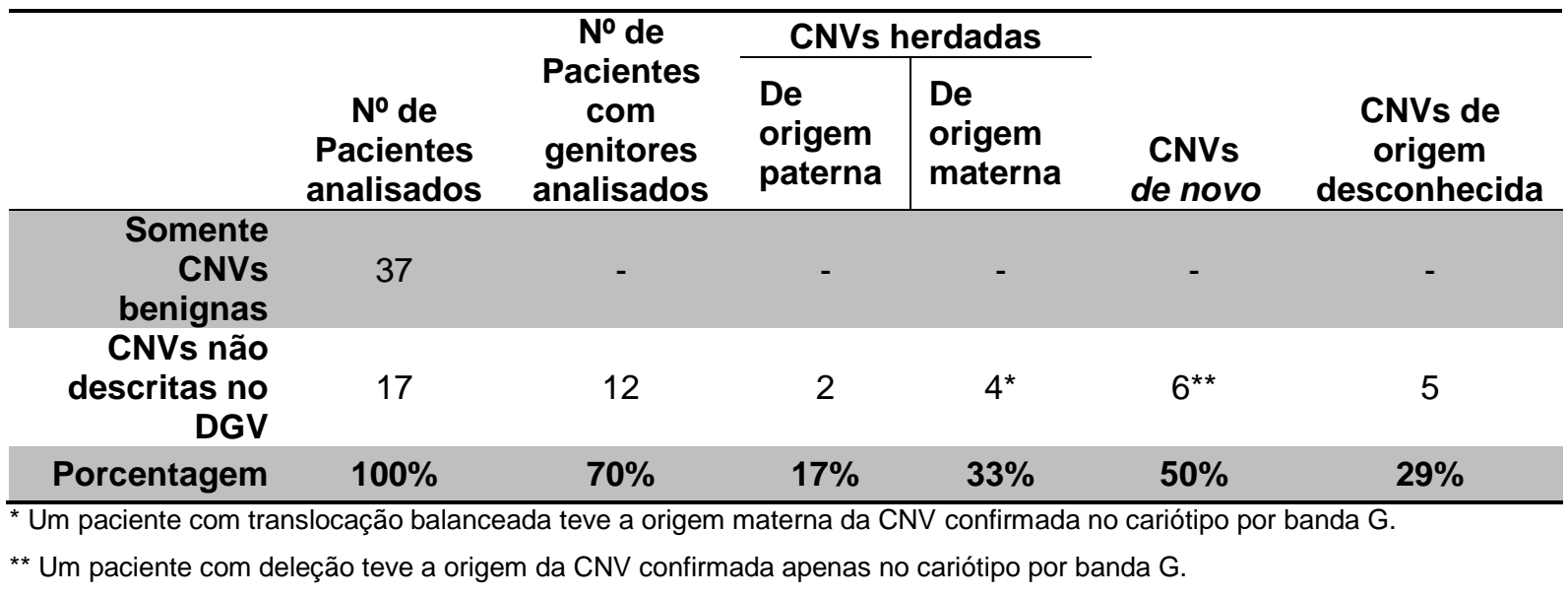

Tabela 4 - Número de pacientes em relação ao tipo, tamanho e origem das CNVs que não estão descritas no DGV encontrada por meio da CMA.

\begin{tabular}{|c|c|c|c|c|}
\hline & $\begin{array}{c}\text { № de } \\
\text { pacientes }\end{array}$ & Porcentagem & $\begin{array}{c}\text { CNVs } \\
\text { de novo }\end{array}$ & Porcentagem \\
\hline Microduplicação (< 5Mb) & 4 & $23 \%$ & 1 & $25 \%$ \\
\hline Microdeleção (< 5Mb) & 7 & $41 \%$ & 3 & $43 \%$ \\
\hline Duplicação (>5Mb) & 0 & $0 \%$ & 0 & $0 \%$ \\
\hline Deleção (>5Mb) & 3 & $18 \%$ & 2 & $66 \%$ \\
\hline $\begin{array}{l}\text { Translocação não } \\
\text { balanceada* }\end{array}$ & 3 & $18 \%$ & 0 & $0 \%$ \\
\hline
\end{tabular}

Observaram-se alterações em 13 dos 24 cromossomos humanos, sendo encontradas CNVs mais frequentemente no cromossomo 3 (três indivíduos com alterações), e nos cromossomos 6, 11, 16 e X (dois indivíduos cada). Outros cromossomos como o 1, 4, 5, 8, 10, 13, 21 e 22 apresentaram apenas um indivíduo cada. Por outro lado, os cromossomos 2, 7, 9, 12, 14, 15, 17, 18, 19, 20 e Y não apresentaram alterações. Na Tabela 5 estão listadas as informações a respeito destas alterações presentes em cada cromossomo em relação aos pacientes. 
Tabela 5 - CNVs encontradas por meio da CMA relacionadas por cromossomo classificadas por tamanho, paciente e origem genética.

\begin{tabular}{|c|c|c|c|c|c|c|c|c|}
\hline \multirow{3}{*}{$\begin{array}{l}\text { Cromo } \\
\text { ssomo }\end{array}$} & \multicolumn{8}{|c|}{ CNVs } \\
\hline & \multicolumn{2}{|c|}{$\begin{array}{c}\text { Microduplicação } \\
\text { (<5 Mb) }\end{array}$} & \multicolumn{2}{|c|}{$\begin{array}{l}\text { Microdeleção } \\
(<5 \mathrm{Mb})\end{array}$} & \multicolumn{2}{|c|}{$\begin{array}{l}\text { Deleção } \\
(>5 \mathrm{Mb})\end{array}$} & \multicolumn{2}{|c|}{$\begin{array}{c}\text { Translocação não } \\
\text { balanceada }\end{array}$} \\
\hline & Paciente & Origem & Paciente & Origem & Paciente & Origem & Paciente & Origem \\
\hline 1 & ACC6 & * & - & - & - & - & - & - \\
\hline 3 & - & - & HUB5 & de novo & - & - & $\begin{array}{l}\text { ACC36 } \\
\text { ACC37 }\end{array}$ & ${ }^{*}{ }^{*}$ \\
\hline 4 & - & - & - & - & ACC20 & * & - & - \\
\hline 5 & - & - & - & - & - & - & ACC31 & * \\
\hline 6 & ACC28 & paterna & ACC42 & materna & - & - & - & - \\
\hline 8 & - & - & ACC22 & de novo & - & - & - & - \\
\hline 10 & - & - & - & - & - & - & АСС36 & * \\
\hline 11 & ACC12 & de novo & ACC10 & de novo & - & - & - & - \\
\hline 13 & - & - & - & - & & & АCС 37 & materna** \\
\hline 16 & HUB3 & * & $\mathrm{ACC} 7$ & materna & - & - & - & - \\
\hline 21 & - & - & - & - & ACC11 & de novo & - & - \\
\hline 22 & - & - & ACC38 & paterna & - & - & - & - \\
\hline$x$ & - & - & АСС33 & * & ACC41 & $\begin{array}{l}\text { de } \\
\text { novo } o^{\star * *}\end{array}$ & - & - \\
\hline $\begin{array}{l}\text { TOTAL } \\
\text { DE } \\
\text { CASOS }\end{array}$ & 4 & 2 & 7 & 6 & 3 & 2 & 3 & 1 \\
\hline
\end{tabular}

No estudo realizado por O'Driscoll e colaboradores (61), levantou a existência de 12 loci cromossômicos em 374 pacientes com ACC onde as anomalias ali encontradas são consistentes para associar ao quadro de ACC, e pelo menos 30 outros loci recorrentes que podem conter genes que contribuem ou causam ACC. No caso da ACC isolada fatores poligênicos parecem estar envolvidos e correlacionados com modificadores genéticos e fatores ambientais. Uma das alterações sugeridas (del $4 \mathrm{p} 16.3$ ) foi encontrada também em uma paciente de nosso estudo, cujo fenótipo sindrômico se enquadrava exatamente ao esperado para uma CNV na região genômica crítica para a Síndrome de Wolf-Hirschhorn (MIM: \#194190) (Tabela 6). Com tantas evidências favoráveis a necessidade de investigar os genitores para saber a origem do fragmento deletado ficou em segundo plano.

Salvo em alguns casos de CNVs que envolvem longos segmentos (acima de 2 $\mathrm{Mb}$ ) e em casos de fenótipos tipicamente sindrômicos, é importante obter as informações dos genitores e dos descendentes disponíveis para maior precisão e 
confiabilidade dos resultados, ajudar na pesquisa de genes que afetam 0 desenvolvimento e a saúde humana, oferecer o suporte clínico necessário para identificação de novas síndromes genéticas e/ou ampliarem a informação sobre síndromes conhecidas. Assim, esclarecer melhor a função dos genes ou regiões genômicas envolvidas contribui para aperfeiçoar os cuidados médicos e os aconselhamentos genéticos para as famílias afetadas (61).

\subsection{ANÁLISE DAS CNVS RARAS}

A Tabela 6 apresenta um detalhamento dos dados citogenômicos das CNVs raras encontradas neste estudo, ou seja, alterações que não são consideradas polimorfismo benigno e, portanto, já descritas no DGV. Ao todo foram registradas, analisadas e interpretadas as dezenove CNVs raras encontradas ao longo do genoma de dezessete pacientes diferentes (dez com CNVs patogênicas; três com CNVs potencialmente patogênicas; e quatro com CNVs VOUS) totalizando um conjunto de alterações cujo tamanho varia desde166 Kb até $49 \mathrm{Mb}$ (incluindo três casos que envolveram translocações não balanceadas).

Os pacientes com CNVs raras clinicamente relevantes, ou seja, CNVs patogênicas, além da alteração do CC, possuem quadro clínico sindrômico e, em alguns casos, cariótipo alterado confirmado após a análise por CMA. Nestes pacientes as informações clínicas disponíveis permitem identificar síndromes com dismorfias craniofaciais, síndromes com características neuroanatômicas/neurológicas primárias, síndromes com fenótipos oculares proeminentes, desordens do espectro das ciliopatias e até alterações metabólicas. Por outro lado, as informações citogenômicas corroboram estes diagnósticos clínicos e permitem atribuir a estes distúrbios genéticos uma correlação com as anomalias do desenvolvimento da linha média, da interferência na migração e especificação neuronal do CC, da alteração na regulação da orientação axonal e da degeneração da sinaptogênese, que determinam maior ou menor grau de interferência no desenvolvimento e na estrutura do CC. 
Tabela 6 - Descrição citogenética e interpretação quanto ao efeito fenotípico de todas as CNVs detectadas pela CMA, listadas por cromossomo, nos pacientes com anomalias do CC e outras malformações associadas.

\begin{tabular}{|c|c|c|c|c|c|c|c|c|c|c|}
\hline Cromossomo & $\begin{array}{l}\text { Tipo de } \\
\text { CNV }^{\star \star \star \star}\end{array}$ & $\begin{array}{c}\text { Banda } \\
\text { cromossômica }\end{array}$ & $\begin{array}{l}\text { Tamanho } \\
(\mathrm{Kb})\end{array}$ & $\begin{array}{l}\text { № de } \\
\text { sondas }\end{array}$ & $\begin{array}{c}\text { Nomenclatura do } \\
\text { CMA }\end{array}$ & $\begin{array}{l}\text { № total } \\
\text { de } \\
\text { genes }^{* *}\end{array}$ & $\begin{array}{c}\text { № de } \\
\text { genes } \\
\text { mórbidos } \\
(\text { OMIM) } \\
\end{array}$ & Origem & Paciente & Interpretação \\
\hline 1 & dup & $1 p 36.33$ & 426 & 168 & $\begin{array}{c}\text { arr[hg19] } \\
\text { 1p36.33p36.32(2,11 } \\
6,349-2,542,740) \times 3\end{array}$ & 15 & 8 & * & ACC6 & $\begin{array}{l}\text { Potencialmen } \\
\text { te patogênica }\end{array}$ \\
\hline 3 & del & $3 q 13.2$ & 3.360 & 836 & $\begin{array}{c}\text { arr[hg19] } \\
3 q 13.2 q 13.31(112,1 \\
44,025- \\
115,504,240) \times 1\end{array}$ & 29 & 14 & de novo & HUB5 & Patogênica \\
\hline 3 & dup & $3 p 26.3$ & 21.471 & 6.404 & $\begin{array}{c}\text { arr[hg19] } \\
3 p 26.3 p 24.3(61,891- \\
21,533,109) \times 3\end{array}$ & 135 & 81 & * & ACC36 & Patogênica \\
\hline 3 & dup & $3 q 26.32$ & 19.398 & 5.985 & $\begin{array}{c}\text { arr[hg19] } \\
\text { 3q26.32q29(178,453 } \\
, 636-197,851,444) \times 3\end{array}$ & 183 & 115 & materna $^{* * * *}$ & ACC37 & Patogênica \\
\hline 4 & del & $4 p 16.3$ & 5.441 & 1.772 & $\begin{array}{c}\text { arr[hg19] } \\
4 p 16.3 p 16.2(68,345- \\
5,509,835) \times 1\end{array}$ & 78 & 45 & * & ACC20 & Patogênica \\
\hline 5 & dup & $5 p 15.33$ & 49.328 & 10.424 & $\begin{array}{c}\text { arr[hg19] } \\
5 p 15.33 q 11.1(113,5 \\
76-49,441,945) \times 3\end{array}$ & 187 & 101 & * & ACC31 & Patogênica \\
\hline 6 & dup & $6 q 15$ & 214 & 68 & $\begin{array}{c}\text { arr[hg19] } \\
6 q 15(90,172,098- \\
90,386,150) \times 3\end{array}$ & 3 & 1 & paterna & ACC28 & vous \\
\hline 6 & del & $6 q 27$ & 2.702 & 816 & $\begin{array}{c}\text { arr[hg19] } \\
6 q 27(168,211,952- \\
170,914,297) \times 1\end{array}$ & 22 & 12 & materna & ACC42 & Patogênica \\
\hline 8 & del & $8 q 12.1$ & 3.438 & 1.024 & $\begin{array}{c}\text { arr[hg19] } \\
8 q 12.1(56,523,670- \\
59,961,677) \times 1\end{array}$ & 21 & 15 & de novo & ACC22 & Patogênica \\
\hline 10 & del & $10 \mathrm{q} 26.3$ & 4.444 & 1.113 & $\begin{array}{c}\text { arr[hg19] } \\
\text { 10q26.3(130,982,03 } \\
5-135,426,386) \times 1\end{array}$ & 41 & 19 & * & ACC36 & Patogênica \\
\hline
\end{tabular}




\begin{tabular}{|c|c|c|c|c|c|c|c|c|c|c|}
\hline 11 & dup & $11 p 15.5$ & 166 & 32 & $\begin{array}{c}\text { arr[hg19] } \\
11 \mathrm{p} 15.5(372,355- \\
538,463) \times 3\end{array}$ & 8 & 5 & de novo & ACC12 & $\begin{array}{l}\text { Potencialmen } \\
\text { te Patogênica }\end{array}$ \\
\hline 11 & del & $11 \mathrm{p} 13$ & 4.960 & 1.816 & $\begin{array}{c}\text { arr[hg19] } \\
11 p 13 p 12(31,813,87 \\
2-36,773,780) \times 1\end{array}$ & 42 & 31 & de novo & ACC10 & Patogênica \\
\hline 13 & del & $13 q 31.1$ & 31.379 & 7.552 & $\begin{array}{c}\text { arr[hg19] } \\
\text { 13q31.1q34(83,591, } \\
362-114,970,605) \times 1\end{array}$ & 134 & 70 & materna ${ }^{\star \star \star *}$ & ACC37 & Patogênica \\
\hline 16 & dup & $16 p 12.2$ & 691 & 160 & $\begin{array}{c}\text { arr[hg19] } \\
16 p 12.2(21,740,199- \\
22,431,031) \times 3\end{array}$ & 10 & 4 & * & HUB3 & VOUS \\
\hline 16 & del & $16 q 23.3$ & 402 & 148 & $\begin{array}{c}\text { arr[hg19] } \\
\text { 16q23.3(82,521,529- } \\
82,923,743) \times 1\end{array}$ & 1 & 1 & materna & $\mathrm{ACC} 7$ & vous \\
\hline 21 & del & $21 q 11.2$ & 7.387 & 1.508 & $\begin{array}{c}\text { arr[hg19] } \\
21 q 11.2 q 21.1(16,11 \\
5,678-23,502,590) \times 1\end{array}$ & 19 & 10 & de novo & ACC11 & Patogênica \\
\hline 22 & del & $22 q 11.21$ & 1.084 & 312 & $\begin{array}{c}\text { arr[hg19] } \\
22 q 11.21(20,716,87 \\
6-21,800,471) \times 1\end{array}$ & 24 & 15 & paterna & ACC38 & $\begin{array}{l}\text { Potencialmen } \\
\text { te Patogênica }\end{array}$ \\
\hline $\mathbf{X}$ & del & Xq21.1 & 31 & 24 & $\begin{array}{c}\text { arr[hg19] } \\
\text { Xq21.1(76,915,402- } \\
76,946,445) \times 1\end{array}$ & 1 & 1 & * & ACC33 & vous \\
\hline $\mathbf{X}$ & del & Xp22.33 & 13.409 & 4.404 & $\begin{array}{c}\text { arr[hg19] } \\
\text { Xp22.33p22.2(168,5 } \\
51-13,577,093) \times 1\end{array}$ & 66 & 54 & $\begin{array}{c}d e \\
\text { novo }^{\star \star \star \star \star}\end{array}$ & ACC41 & Patogênica \\
\hline
\end{tabular}

* Dados não disponíveis.

** Número total de genes envolvidos nas alterações cromossômicas.

${ }^{* * *}$ del = deleção; dup = duplicação.

**** Resultado confirmado no cariótipo por banda G por envolver translocação balanceada.

${ }^{\star * \star * \star}$ Apenas disponíveis os dados do cariótipo por banda $G$ dos pais. 
Ao invés de uma única via genética relacionada à ACC existem diversas interações complexas entre múltiplos genes. Consequentemente, atualmente já foram listados o envolvimento mais de 100 genes humanos, e um número ainda maior em cobaias, e mais de 200 síndromes genéticas associadas com ACC listadas no banco de dados do OMIM (40,61). A maioria destas condições possuem fenótipos variados e características clínicas neuroanatômicas e comorbidades que podem variar entre os indivíduos de uma mesma família ou entre famílias (48).

Diferentes tipos de resultados clinicamente relevantes foram obtidos através dos exames de array. As propostas de interpretação do significado clínico e fenotípico das CNVs encontradas neste estudo seguem as sugestões feitas por diferentes autores $(26,128-130)$. Das CNVs consideradas causativas dos fenótipos analisados, observa-se que nenhuma alteração foi recorrente em nossa amostra sugerindo assim a natureza ampla e heterogênea da etiologia genética das anomalias do CC.

Neste estudo, $76 \%$ dos indivíduos, que tiveram suas CNVs classificadas como patogênicas ou potencialmente patogênicas, apresentaram uma única alteração que foi suficiente para determinar ou associar à patologia. O que normalmente determina a patogenicidade de uma CNV é a região afetada, o(s) gene(s) envolvido(s), o tamanho do fragmento alterado, se é microdeleção ou microduplicação (122).

No grupo dos dez pacientes com CNVs patogênicas foi possível observar pacientes com fenótipos sindrômicos decorrentes de translocações não balanceadas, observadas posteriormente ao cariótipo, com alterações que envolvem grandes segmentos cromossômicos, variando entre 7,3 Mb e $49 \mathrm{Mb}$, e comprometendo muitos genes relevantes nos cromossomos em que estão presentes: uma paciente (ACC31) com um trissomia do braço curto do cromossomo 5 que foi translocado para o cromossomo 15; um paciente (ACC36) caracterizado clinicamente pela Síndrome Alcoólica Fetal, com translocação não equilibrada entre segmento do braço curto do cromossomo 3 e porção distal do braço longo do cromossomo 10 definindo uma t(3;10); e um paciente (ACC37) com suspeita clínica para Síndrome de Fryns (MIM \#229850) com uma t(3;13) causada por uma duplicação da parte distal do braço longo do cromossomo 3 e uma deleção no braço longo do 13 (Tabela 7).

Neste estudo foi encontrado maior número de microdeleções, mais prováveis de serem causadoras de uma alteração fenotípica, comparado ao de 
microduplicações, mais comum no genoma humano. Segundo Battaglia e colaboradores (102), duplicações geralmente causam um fenótipo mais leve, possibilitando que ocorram em maior número em virtude de seu prognóstico favorável. E ainda, no caso das duplicações existem mecanismos adicionais que possibilitam manter a homeostase no caso de produção excessiva de um RNA ou uma proteína, como promover a eliminação acelerada via degradação ou exocitose do RNA e/ou proteína produzidos em excesso (152)

No entanto, um fator a ser levado em conta são os genes sensíveis à dosagem na expressão e que não possuem mecanismos regulatórios para compensar o efeito de dose exercido por uma deleção ou duplicação. Outro mecanismo que pode contribuir para uma maior patogenicidade das deleções é a possibilidade da combinação da deleção do alelo de um gene com outro homólogo disfuncional por mutação ou por imprinting que causa uma condição autossômica recessiva. Por isso, a ativação ou inativação significativa de um ou mais genes sensíveis à dosagem é um dos fatores que determina o impacto que a CNV tem sobre o fenótipo e/ou anomalias fenotípicas, e dificulta a interpretação de CNVs consideradas benignas quando a deleção contém genes causadores de doenças recessivas (152).

A CMA revelou um grupo de pacientes que apresenta grandes fragmentos cromossômicos deletados, como foi o caso da paciente (ACC41) que possui uma deleção terminal do braço curto do $X$ de $13,4 \mathrm{Mb}$ e suspeita clínica para Síndrome de MIDAS (acrônimo do inglês para Mlcrophtalmia, Dermal Aplasia, and Sclerocornea) ou das anomalias congênitas múltiplas com defeito lineares de pele (MIM \#309801); uma paciente (ACC20) com suspeita clínica para Síndrome de WolfHirschhorn (MIM \#194190) e deleção de 5,4 Mb no braço curto do cromossomo 4; e do paciente (ACC11) com uma deleção de 7,3 Mb no braço longo do cromossomo 21. Quatro pacientes apresentaram microdeleções que, pelo tamanho do fragamento alcançado, possuem correlação direta com fenótipos incluindo a má formação do CC: uma paciente (ACC10) com indicação clínica para Síndrome de WAGR

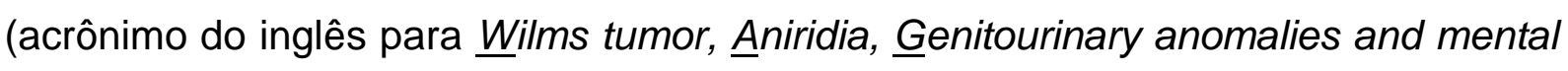
Retardation) MIM \#194072 e deleção de 4,9 Mb no braço curto do cromossomo 11; um paciente (ACC22) que apresenta um deleção de 3,4 Mb no braço longo do cromossomo 8; uma paciente (ACC42) com deleção 6q27 de 2,7 Mb; e, finalmente, uma paciente (HUB5) que apresentou uma microdeleção de 3,3 Mb em 3q13 e suspeita clínica prévia para Síndrome de Kabuki (MIM\#147920) (Tabela 7). 
Dentre o grupo das três pacientes com CNVs potencialmente patogênicas, as alterações envolvem genes e regiões genômicas que podem causar anomalias no $\mathrm{CC}$, dependendo do tipo do padrão de herança gênica envolvida: como é o caso de uma paciente (ACC6) com uma microduplicação de $426 \mathrm{~Kb}$ em 1p36.33 (região bem descrita para Síndrome da deleção de 1 p36 - MIM \#607872); uma paciente (ACC12) cuja microduplicação de $166 \mathrm{~Kb}$ em 11 p15.5 está em uma região com diversas síndromes descritas que possuem correlação com as malformações do CC; e, finalmente, uma paciente com microdeleção de $1 \mathrm{Mb}$ em 22q11.21, cujo resultado da CMA permitiu fundamentar a hipótese diagnóstica da Síndrome de CEDNIK (acrônimo do inglês para CErebral Dysgenesis, Neuropathy, Ichthyosis, and palmoplantar KEeratoderma) MIM \#609528 (Tabela 8).

Apesar do grande volume de informações geradas pelo SNP-array de alta resolução, determinar o significado clínico das CNVs identificadas no paciente depende do trabalho meticuloso, da expertise e do conhecimento do pesquisador. Neste sentido, Miller e colaboradores (29) observaram que relatórios de CNVs registradas por laboratórios clínicos diferentes indicam uma ampla variabilidade de interpretação.

Uma das vantagens da CMA de alta resolução é a sua capacidade de detectar microdeleções, permitindo o diagnóstico de doenças e/ou anomalias fenotípicas causadas por poucos ou um único gene, e identificar genes em que um alelo não supre a cópia deletada do outro provocando o aparecimento do fenótipo alterado e permitindo obter o diagnóstico de haploinsuficiência (29). Além disso, um dos fatores que mais contribuíram para a melhoria na taxa de diagnósticos nos exames de CMA foi o aumento da resolução e a maior cobertura genômica alcançada pelas novas plataformas.

No grupo dos quatro pacientes com microdeleções/microduplicações sem significado clínico conhecido, os tamanhos das alterações encontradas variam entre $31 \mathrm{~Kb}$ e 3,4 Mb. Apesar de serem alterações que não são observadas na população em geral, elas não possuem informações citogenômicas disponíveis sobre a região e/ou genes afetados suficientes para alegar a correlação com as malformações do CC. Um paciente (ACC7) com uma (Tabela 9). 
Tabela 7 - CNVs patogênicas, detectadas por meio da CMA, em pacientes com anomalias do CC e outras malformações associadas, listando os principais genes e/ou região genômica que sugerem correlação com as malformações do CC.

\begin{tabular}{|c|c|c|c|c|c|c|c|c|c|}
\hline $\begin{array}{l}\text { Código } \\
\text { Paciente }\end{array}$ & Sexo & Idade & CC & Cariótipo & $\begin{array}{c}\text { Resultado da CMA } \\
\text { (hg19) }\end{array}$ & Origem & $\begin{array}{l}\text { Tamanho } \\
(\mathrm{Mb})\end{array}$ & $\begin{array}{c}\text { GENE / região } \\
\text { candidata } \\
\text { (OMIM) }\end{array}$ & $\begin{array}{c}\text { Principais alterações } \\
\text { clínicas }\end{array}$ \\
\hline ACC10 & $\mathrm{F}$ & $\begin{array}{l}2 \text { anos e } \\
9 \text { meses }\end{array}$ & Hipoplasia & $46, X X$ & $\begin{array}{c}\text { del 11p13p12 } \\
(31,813,872-36,773,780)\end{array}$ & de novo & 4,9 & $\begin{array}{l}\text { WT1 (607102), } \\
\text { PAX6 (194072) }\end{array}$ & $\begin{array}{l}\text { ADNPM, Dis. faciais, } \\
\text { AO, AC, AG, DM, DA, } \\
\text { Dis. membros }\end{array}$ \\
\hline ACC11 & M & $\begin{array}{c}1 \text { ano e } 4 \\
\text { meses }\end{array}$ & DCC & $\begin{array}{l}46, X Y(\text { del2 } \\
\text { 1)(q22) }\end{array}$ & $\begin{array}{c}\text { del 21q11.2q21.1 } \\
(16,115,678-23,502,590)\end{array}$ & de novo & 7,3 & NCAM2 (602040) & Dis. faciais \\
\hline ACC20 & $\mathrm{F}$ & $\begin{array}{l}2 \text { anos e } \\
9 \text { meses }\end{array}$ & DCC & $46, X X$ & $\begin{array}{l}\text { del 4p16.3p16.2 } \\
(68,345-5,509,835)\end{array}$ & * & 5,4 & WHSC1(602952) & $\begin{array}{l}\text { Dis. faciais, AO, Conv, } \\
\text { DF, DM, DA }\end{array}$ \\
\hline ACC22 & M & 6 meses & DCC & * & $\begin{array}{c}\text { del 8q12.1 } \\
(56,523,670-59,961,677)\end{array}$ & de novo & 3,4 & $\begin{array}{l}\text { Região 8q12 } \\
\text { (15 genes) }\end{array}$ & $\begin{array}{l}\text { Dis.faciais, AO, AA, } \\
\text { Conv, Dis. membros }\end{array}$ \\
\hline ACC31 & $\mathrm{F}$ & 2 meses & ACC & $\begin{array}{l}46, X X, \operatorname{der}( \\
5) t(5 ; 15)(q 1 \\
? ; q 1 ?)\end{array}$ & $\begin{array}{r}\text { dup } 5 p 15.33 q 11.1 \\
(113,576-49,441,945)\end{array}$ & * & 49,3 & $\begin{array}{l}\text { Região } 5 p 15.33 \\
\text { (101 genes) }\end{array}$ & $\begin{array}{l}\text { Dis. faciais, AO, Dis. } \\
\text { membros }\end{array}$ \\
\hline ACC36 & $\mathrm{M}$ & 7 meses & DCC & * & $\begin{array}{c}\text { dup 3p24.3p26.1 } \\
(61,891-21,533,109) \\
\text { del 10q26.3 } \\
(130,982,035-135,426,386)\end{array}$ & * & $\begin{array}{r}21,4 \\
4,4\end{array}$ & $\begin{array}{l}\text { CRBN (609262), } \\
\text { SETD5 (615743) }\end{array}$ & $\begin{array}{l}\text { Dis. faciais, Dis. } \\
\text { membros }\end{array}$ \\
\hline ACC37 & M & 1 mês & ACC & $\begin{array}{l}\text { 46, XY, } \\
\operatorname{der}(13)\end{array}$ & $\begin{array}{c}\text { dup 3q26.33-q29 } \\
(178,453,636-197,861,444) \\
\text { del 13q31.1q34 } \\
(83,591,362-114,970,605)\end{array}$ & $\begin{array}{l}\text { materna } \\
\mathrm{t}(3 ; 13)^{\star *}\end{array}$ & $\begin{array}{l}19,3 \\
31,3\end{array}$ & $\begin{array}{l}\text { SOX2 (184429), } \\
\text { ZIC2 (603073), } \\
\text { NALCN (611549) }\end{array}$ & $\begin{array}{l}\text { Dis. faciais, Dis. } \\
\text { membros }\end{array}$ \\
\hline ACC41 & $\mathrm{F}$ & 12 anos & ACC & $\begin{array}{l}\text { 46,X,del }(X) \\
(p 22.1)\end{array}$ & $\begin{array}{c}\text { del Xp22.2-p22.33 } \\
(168,551-13,577,093)\end{array}$ & * & 13,4 & HCCS (309801) & $\begin{array}{l}\text { ADNPM, Dis. faciais, } \\
\text { DF, DA,Dis.membros }\end{array}$ \\
\hline ACC42 & $\mathrm{F}$ & $\begin{array}{l}1 \text { ano e } \\
10 \text { meses }\end{array}$ & Hipoplasia & )$^{46, X \times\left(9 q h^{+}\right.}$ & $\begin{array}{c}\text { del 6q27 } \\
(168,211,952-170,914,297)\end{array}$ & materna & 2,7 & ERMARD (615532) & $\begin{array}{l}\text { ADNPM, Dis. faciais, } \\
\text { DF, DM, DA }\end{array}$ \\
\hline HUB5 & $\mathrm{F}$ & 11 anos & DCC & $46, X X$ & $\begin{array}{c}\text { del 3q13.2-q13.31 } \\
(112,144,025-115,504,240)\end{array}$ & de novo & 3,3 & GAP43 (162060) & $\begin{array}{l}\text { ADNPM, Dis. faciais, } \\
\text { DM, DA, Dis.membros }\end{array}$ \\
\hline
\end{tabular}


Tabela 8 - CNVs potencialmente patogênicas, detectadas por meio da CMA, em pacientes com anomalias do CC e outras malformações associadas, listando os principais genes e/ou região genômica que possivelmente estão correlacionados com as malformações do CC.

\begin{tabular}{|c|c|c|c|c|c|c|c|c|c|}
\hline $\begin{array}{l}\text { Código } \\
\text { Paciente }\end{array}$ & Sexo & Idade & $\mathrm{CC}$ & Cariótipo & $\begin{array}{c}\text { Resultado da CMA } \\
\text { (hg19) }\end{array}$ & Origem & Tamanho & $\begin{array}{l}\text { GENE / região } \\
\text { candidata } \\
\text { (OMIM) }\end{array}$ & $\begin{array}{c}\text { Principais alterações } \\
\text { clínicas }\end{array}$ \\
\hline ACC6 & $\mathrm{F}$ & 8 anos & DCC & $46, X X$ & $\begin{array}{c}\text { dup 1p36.33p36.32 } \\
(2,116,349-2,542,740)\end{array}$ & * & $426 \mathrm{~Kb}$ & $\begin{array}{l}\text { Região 1p36.33 } \\
\text { (8 genes) }\end{array}$ & $\begin{array}{l}\text { ADNPM, Dis. faciais, AO, DI, } \\
\text { conv.,DF, DM, DA, } \\
\text { Dis.membros }\end{array}$ \\
\hline $\mathrm{ACC} 12$ & $\mathrm{~F}$ & $\begin{array}{l}2 \text { anos e } \\
8 \text { meses }\end{array}$ & DCC & $46, X X$ & $\begin{array}{c}\operatorname{dup} 11 \mathrm{p} 15.5 \\
(372,355-538,463)\end{array}$ & de novo & $166 \mathrm{~Kb}$ & $\begin{array}{l}\text { Região } 11 p 15.5 \\
\quad \text { (5 genes) }\end{array}$ & $\begin{array}{l}\text { Dis. faciais, AO, Dis. } \\
\text { membros }\end{array}$ \\
\hline ACC38 & $\mathrm{F}$ & 8 meses & ACC & $46, X X$ & $\begin{array}{c}\text { del 22q11.21 } \\
(20,716,876-21,800,471)\end{array}$ & paterna & $1 \mathrm{Mb}$ & SNAP29 (604202) & ADNPM, Dis. faciais, DM \\
\hline
\end{tabular}

Tabela 9 - CNVs de significado clínico desconhecido (VOUS), detectadas por meio da CMA, em pacientes com anomalias do CC e outras malformações associadas.

\begin{tabular}{|c|c|c|c|c|c|c|c|c|c|c|}
\hline $\begin{array}{l}\text { Código } \\
\text { Paciente }\end{array}$ & Sexo & Idade & CC & Cariótipo & $\begin{array}{l}\text { Resultado da CMA } \\
\text { (hg19) }\end{array}$ & Origem & Tamanho & $\begin{array}{l}\text { № total } \\
\text { de genes }\end{array}$ & $\begin{array}{c}\text { GENE / região } \\
\text { candidata } \\
\text { (OMIM) }\end{array}$ & $\begin{array}{c}\text { Principais } \\
\text { alterações } \\
\text { clínicas } \\
\end{array}$ \\
\hline ACC 7 & M & 3 anos & ACC & $46, X Y$ & $\begin{array}{c}\text { del 16q23.3 } \\
(82,521,529-82,923,743)\end{array}$ & materna & $402 \mathrm{~Kb}$ & 1 & $\begin{array}{c}C D H 13 \\
(601364)\end{array}$ & $\begin{array}{l}\text { Dis. faciais, AO, } \\
\text { Dis.membros }\end{array}$ \\
\hline ACC 28 & M & 9 meses & ACC & $46, X Y$ & $\begin{array}{c}\text { dup } 6 q 15 \\
(90,172,098-90,386,150)\end{array}$ & paterna & $214 \mathrm{~Kb}$ & 3 & $\begin{array}{l}\text { ANKRD6 } \\
(610583)\end{array}$ & $\begin{array}{l}\text { ADNPM, Dis. } \\
\text { faciais, AO, } \\
\text { conv.,DM, }\end{array}$ \\
\hline ACC33 & $\mathrm{F}$ & 2 meses & ACC & * & $\begin{array}{c}\text { del Xq21.1 } \\
(76,915,402-76,946,445)\end{array}$ & * & $31 \mathrm{~Kb}$ & 1 & $\begin{array}{c}\text { ATRX } \\
(300032)\end{array}$ & Dis. faciais, $A O, A A$ \\
\hline HUB3 & M & 19 anos & DCC & $46, X Y$ & $\begin{array}{c}\operatorname{dup} 16 p 12.2 \\
(21,740,199-22,431,031) \\
\end{array}$ & * & $690 \mathrm{~Kb}$ & 10 & $\begin{array}{l}E E F 2 K \\
(606968)\end{array}$ & $\begin{array}{l}\text { Dis. faciais, } \\
\text { DI,Dis.membros }\end{array}$ \\
\hline
\end{tabular}


Embora a detecção de um CNV não seja, necessariamente, uma prova de que ela seja causadora de uma anomalia como, por exemplo, na ACC, o suporte em evidências adicionais tais como, a falta de um diagnóstico causal alternativo, a sobreposição da CNV encontrada com aquelas presentes em outros pacientes com manifestações clínicas semelhantes, a evidência funcional do(s) gene(s) ser(em) importante(s) no desenvolvimento do CC, auxiliarão na interpretação clínica dos estudos cromossômicos (34).

Um dos exemplos mais notáveis na literatura que mostra a associação entre uma CNV e a ACC, e que talvez ilustre as dificuldades de se interpretar o impacto de uma alteração numérica sobre o fenótipo, é a associação estabelecida entre ACC e microcefalia pós-natal e a Síndrome da Deleção 1q42-44 (61). O principal locus nesta região, aparentemente, está em 1q44 onde se encontra o gene AKT3 (OMIM: 611223). Em mais de $90 \%$ dos pacientes com ACC e microcefalia encontraram deletado o AKT3, um gene que promove a sobrevivência neuronal em modelos animais $(153,154)$. No entanto, alguns pacientes que apresentam deleção 1q42-44 que não afeta o AKT3 sugerem que exista, pelo menos, mais um gene neste locus $(155,156)$. A haploinsuficiência de outros genes, como no caso do DISP1 (OMIM: 607502) localizado em 1q41, tem sido sugerida como a causa dos defeitos no desenvolvimento da linha média. Em particular, o gene ZBTB18 (OMIM: 608433) é o candidato mais promissor depois que encontraram um paciente com microcefalia pós-natal e ACC com translocação recíproca com um ponto de quebra entre AKT3 e ZBTB18 (153,157). Na verdade, provavelmente existem mais genes envolvidos, refletindo em defeitos combinados tanto na linha média quanto na formação do eixo lateral $(61,158)$.

Em alguns casos, provavelmente os efeitos fenotípicos das microdeleções ou microduplicações são resultado da ruptura da ação sinérgica entre dois ou mais genes. llustrando esse cenário, sabe-se que a Síndrome de Miller-Dieker (MIM \#247200) caracterizada pela combinação clássica de lisencefalia, microcefalia, convulsões e dismorfias faciais é mais grave que a forma isolada da lisencefalia. Em ambos os casos, o gene LIS1 (OMIM: 607432) está afetado e o fenótipo mais grave da Síndrome de Miller-Dieker é atribuído à deleção do gene YWHAE (OMIM: 607432) que se localiza distalmente ao LIS1 (159). Esses dois genes estão envolvidos na migração neuronal interagindo entre si de forma indireta (160). Surpreendentemente, pacientes com microduplicações em 17p13.3 apresentam uma 
forma mais grave do espectro autista quando apenas LIS1 está duplicado, sugerindo que as interações entre as proteínas dos genes candidatos estejam relacionadas com a patogênese desta síndrome (159).

Rearranjos em $8 p$ são frequentemente associados com malformações cerebrais. A inversão da duplicação/deleção de $8 p$ é uma das mais conhecidas e resultam em malformações do cérebro incluindo ACC e problemas na fala (61). Wilson e colaboradores (161) identificaram ACC em $25 \%$ dos casos publicados de rearranjos em $8 p$ com agenesia calosal embora variações na penetrância existam dependendo do tipo de rearranjo. Como ACC é, aparentemente, mais comum na inversão da duplicação/deleção o mais provável é que esteja ocorrendo o envolvimento de dois loci, onde um contribui para ACC quando estiver deletado e o outro que contribui quando duplicado. Esta explicação é corroborada pela recente descrição de ACC em dois pacientes com duplicações apenas em 8p (151).

Outro exemplo envolvendo interpretação de CNV seria o da Síndrome da deleção 1p36 ou monossomia 1p36 (MIM \#607872) que é uma das deleções cromossômicas mais comuns (incidência de 1 para cada 5.000 nascidos) mas com uma penetrância relativamente baixa (5,8\%) (162). As alterações fenotípicas variadas da Síndrome e as aparentes correlações genótipos-fenótipos ilustram bem a complexidade das síndromes que envolvem genes contíguos. Os problemas neurológicos mais comuns incluem paquigiria, polimicrogiria, hidrocefalia e ACC (162). A haploinsuficiência de genes contíguos, mas não relacionados funcionalmente, foi sugerido ser a responsável pelas variações fenotípicas registradas $(163,164)$; entretanto, a expressão de genes à longa distância pode afetar por meio do efeito de posição da deleção (165). E mais, fatores epigenéticos e modificadores podem contribuir para o fenótipo, dificultando apontar quais os genes causadores específicos em uma situação de deleção contigua.

A relevância de se utilizar CMA para casos de ACC é evidenciada pelas frequências diagnósticas que foram obtidas em diversos trabalhos. Neste estudo 19 CNVs raras foram encontradas e a taxa diagnóstica de $24 \%$ encontrada demonstrou o alto percentual de diagnóstico da técnica para esta condição quando associada com outras malformações. Por exemplo, Beaudet (166) teve um rendimento diagnóstico de $20 \%$ a $25 \%$ em um estudo com 42 indivíduos com DI, e afirmou que há maior probabilidade de se encontrar CNVs patogênicas quando a DI está 
associada com dismorfias. Portanto, a taxa diagnóstica da CMA não diminui quando são utilizados dois ou mais critérios dismorfológicos.

Diversas síndromes com ACC ainda permanecem sem ter um gene causador identificado como, por exemplo, nos casos de Síndrome de Aicardi (OMIM 304050), dentre outras. Delinear e confirmar a causa genética de síndromes não herdáveis é complexo por conta da elevada incidência de mutações de novo, heterogeneidade genética e dificuldade em se obter um diagnóstico consistente. Muitas dessas síndromes possuem diversos órgãos afetados o que aumenta as chances de se encontrar uma etiologia genética. Outra possibilidade que o uso do array trouxe foi o de poder agrupar quadros clínicos que estão etiologicamente correlacionados em várias destas síndromes, antes consideradas distintas (86).

Importante observar que a ACC, dentre os quadros sindrômicos relacionados com ADNPM e/ou DI, é a mais frequente e a que menos se conhece a etiologia. $A$ maioria dos casos envolvem problemas genéticos de variados tipos e que, muitas vezes, dificultam o entendimento acerca do envolvimento das alterações submicroscópicas que sempre foram negligenciadas pela citogenética convencional. Agora, está sendo possível descobrir que microdeleções e microduplicações estão presentes de forma significativa nestes casos e impactam no fenótipo de patologias consideradas, até então, uma incógnita para os pesquisadores (34).

O presente trabalho corrobora estas considerações acrescentando mais dados moleculares e dando suporte epidemiológico para a indicação clínica da solicitação do exame de CMA por parte do clínico geneticista. Observou-se aqui que nos casos onde há ACC associada com ADNPM e/ou DI, dismorfias de cabeça/face e alterações de membros é válido fazer o pedido do exame de CMA como opção de teste de primeira linha, estratégia defendida por diversos outros estudos $(6,29,94$, 98-103). As chances de se obter um diagnóstico genético específico são grandes, o que facilitaria a assistência médica adequada, aconselhamento genético específico para a família e, em última instância, uma melhor condição de vida para o próprio paciente.

A ACC permanece sendo um dos mais complexos defeitos neurológicos congênitos conhecidos em virtude do amplo número de processos do desenvolvimento que podem ser perturbados. Como corolário, a ACC que raramente ocorre na forma isolada, é um marcador fenotípico dos distúrbios do desenvolvimento específico e relativamente fácil de ser detectado. 
desenvolvimento do CC pode ser afetado por distúrbios durante a neurogênese, a formação da linha média telencefálica, a migração e especificação neuronal, o desenvolvimento do direcionamento e do pós-direcionamento axonal. Estudos recentes identificaram um grande número de CNVs e mutações gênicas em pacientes com ACC, mas apenas conseguiram elucidar a complexidade genética em algumas síndromes com ACC. Além disso, com auxílio de dados fornecidos pelo constante avanço das técnicas de neuroimagens foi possível entender na prática como as mutações afetam a conectividade cerebral e como o cérebro responde aos distúrbios do desenvolvimento. Estes enfoques, juntos com estudos em modelos animais, têm aumento o nosso grau de entendimento acerca dos mecanismos envolvidos na agenesia calosal (45).

A base biológica da ACC é complexa refletindo no grande número de doenças humanas congênitas associadas com a anomalia do desenvolvimento do CC. Talvez esta condição seja um dos mais complexos mecanismos neurológicos descritos relacionados aos defeitos congênitos, visto que vários processos do desenvolvimento estão envolvidos no fenótipo da ACC. Sendo assim, sua observação é um excelente modelo para o entendimento de muitas outras doenças neurológicas e psiquiátricas com componentes do neurodesenvolvimento. $O$ entendimento das bases dos vários distúrbios associados com ACC, como esquizofrenia e autismo, requer não apenas a identificação dos genes que regulam cada um destes processos, mas também o melhor entendimento da função de cada um desses genes e como eles trabalham isoladamente e juntos na sobreposição de vias moleculares para formarem o CC (34).

De modo similar ao que ocorre em diversas outras desordens psiquiátricas, a ACC resulta do desenvolvimento anormal da conectividade neural. Além disso, a ACC fornece um excelente desafio para a integração das tecnologias de neuroimagem no que diz respeito a visualização da conectividade alterada e poder produzir um mapa funcional dos cérebros com ACC. Estas informações são cruciais para o entendimento das questões sobre a reorganização cortical e subcortical no cérebro humano (60).

Inclusive existem algumas similaridades estruturais entre o cérebro com ACC e com desordens psiquiátricas como autismo e esquizofrenia. Diversos estudos encontraram alterações na forma e no tamanho do CC em pacientes com esquizofrenia assim como diferenças microestruturais na matéria branca reveladas 
por exames de neuroimagem (167). Em geral, as desordens neuropsiquiátricas como a esquizofrenia são consideradas herança poligênica na qual a desordem é influenciada pela combinação de muitos modificadores genéticos. Uma exceção a esta regra, entretanto, seriam as mutações no gene DISC1 que estão relacionadas tanto com ACC quanto com uma pequena parcela dos casos de esquizofrenia (168). O gene DISC1 inibe a proliferação neuronal causando a saída do ciclo celular e da diferenciação (169).

Estudos observaram que indivíduos com autismo (57) e com Transtorno do Espectro Autista (TEA) (170) podem apresentar redução do tamanho do CC. Inclusive, Lau e colaboradores (57) sugeriram que os indivíduos com ACC devem ser examinados para TDEA e que as desordens do CC precisam ser consideradas na avaliação do diagnóstico autista. As estimativas de estudos antigos antes do ano 2000 estimavam em cerca de 10\% o número de indivíduos que recebiam o diagnóstico formal autista. Mais recentemente resultados obtidos a partir de instrumentos mais modernos sugerem que, na verdade, entre $30 \%-50 \%$ das crianças e adolescentes com ACC, e cerca de $20 \%$ dos adultos, exibem uma clara sintomatologia autista (171). Evidências também suportam a hipótese de que a anomalia congênita do CC constitui o principal fator de risco para o desenvolvimento do autismo (171). Outros estudos demonstraram mudanças no CC de pacientes com Síndrome de Tourette - MIM \#137580 (172) e com Transtorno do Déficit de Atenção e Hiperatividade (TDAH) (173).

Neste estudo observou-se uma baixa representatividade de indivíduos com ACC e sintomatologia autista (5\%) (Tabela 1). Conforme observado no estudo de Paul e colaboradores (171), uma parcela pequena dos indivíduos (3 em 22) com ACC apresentaram sintomatologia autista suficiente para conseguirem serem formalmente diagnosticados ainda na infância. Outro detalhe lembrado pelos autores foi que indivíduos com ACC apresentam os fenótipos da sintomatologia autista mais tardiamente (aos 6 e 11 anos) do que nos períodos esperados tradicionalmente (aos 3 anos). Isso pode explicar o observado no presente estudo visto que $78 \%$ dos pacientes do possuíam idade inferior ou igual a 5 anos; e outro detalhe que pode ter contribuído para a baixa porcentagem de casos seria a tendência dos pacientes que apresentam indicação clínica de sintomatologia autista no atendimento primário, mesmo que apresentem ACC, sejam encaminhados prioritariamente para os Serviços de Psiquiatria da rede e não para os serviços de Genética Médica. 
Por fim, a caracterização neurofisiológica e comportamental dos indivíduos portadores de ACC ajudará a esclarecer as diferenças entre os diversos diagnósticos comportamentais facilitando 0 entendimento dos mecanismos envolvendo as características cognitivas e psicossociais que são comuns à ACC. E ainda, com esta informação será possível desenvolver intervenções mais adequadas para os déficits em indivíduos com ACC, como habilidades sociais, resolução de problemas e planejamento, melhorando a qualidade de vida destes indivíduos. 


\subsection{ANÁLISE DAS CNVS PATOGÊNICAS:}

\subsubsection{Paciente ACC10}

A paciente ACC10 é uma menina de dois anos e três meses de idade, com cariótipo normal $(46, X X)$, possui hipoplasia do CC revelada por TC de crânio, cujo fenótipo com múltiplas malformações inclui ADNPM, algumas dismorfias faciais (braquicefalia, hipertelorismo ocular, orelhas rodadas para trás, úvula bífida, fenda palatina), anomalias nos membros (braquidactilia, mãos rígidas), poliesplenia, abdômen globoso e distendido, alterações cardíacas (persistência do canal arterial, má formação das veias cavas, derrame pericárdico moderado), alterações gastroenterológicas (disfagia, estenose subglótica), anomalias genitourinárias (hipertrofia clitoriana, rins policísticos, Tumor de Wilms no rim direito). Laudos relatam que ela ainda teve leucomalácia cística periventricular, doença da membrana hialina, icterícia e pneumonia.

A CMA constatou a presença de uma microdeleção de novo com 4,9 $\mathrm{Mb}$ em 11p13-12 (31,813,872-36,773,780), afetando uma região contendo 42 genes, dos quais 31 possuem alguma morbidade descrita no OMIM e de onde se destacam os seguintes genes candidatos a serem os causadores de malformação no CC: PAX6 (OMIM: 607108) e WT1 (OMIM: 607102) (Figura 8). O quadro clínico da paciente é compatível com o diagnóstico da Síndrome de WAGR (MIM \#194072), normalmente causada por microdeleções nesse segmento.

O gene PAX6 é o mais bem estudado de uma família de reguladores de transcrição denominada $P A X$, e faz parte de um grupo de genes de controle da organização do sistema visual durante a embriogênese. A proteína de PAX6 é um fator de regulação transcricional altamente conservado com funções importantes para o desenvolvimento normal dos olhos e do sistema nervoso. Frequentemente encontram-se indivíduos com anomalias estruturais associadas aos distúrbios no sistema nervoso central, incluindo hipoplasia (174-177) ou ACC completa (178). Embora nenhuma anomalia cerebral tenha sido atribuída diretamente à mutação de PAX6, alguns estudos tentam atribuir o efeito de algumas mutações sobre o fenótipo (174; 177; 178). Abouzeid e colaboradores (178) hipotetizaram que uma mutação específica poderia causar anomalias cerebrais, como PAX6 é um fator de transcrição, sua proteína poderia interagir com vários genes do desenvolvimento 
cerebral e outros fatores de transcrição, como genes da família Homeo-box, cuja interação com produtos protéicos Hesx1 ou Emx2, causaria a hipoplasia do CC. No entanto, Kelberman e colaboradores (179) afirmam que para mutações em PAX6 e SOX2 é mais comum encontrar hipoplasia do CC do que ACC parcial ou completa.

Como a paciente ACC10 tem ACC completa, talvez o agravamento do quadro de ACC comparado com os relatos na literatura de fenótipo mais brando, seria uma consequência da deleção afetar outro gene (WT1) de complexa biologia funcional e que reconhecidamente interfere no desenvolvimento do tecido neural durante a embriogênese. Assim como estudos in vitro e com modelos animais já revelaram que a sua expressão é coincidente com a diferenciação de células neuronais e células gliais $(180,181)$. Porém nenhum estudo foi feito para analisar o seu papel na etiologia molecular do CC humano principalmente no que se refere à sua expressão durante os eventos de formação de linha média, migração e diferenciação neuronal, e avaliar seu papel na interação com outros genes relacionados ao desenvolvimento do CC.

O gene do tumor de Wilms 1 (WT1) foi identificado pela primeira vez em pacientes com a Síndrome de WAGR que apresentavam deleções no cromossomo 11. O WT1 codifica um fator de transcrição que pode atuar como supressor tumoral, ou como oncogene, dependendo do contexto em que a célula se encontra o que sugere que ele desempenhe diferentes papéis no crescimento e desenvolvimento celular $(182,183)$. O WT1 é considerado um gene importante que está envolvido na diferenciação celular. Os efeitos de oncogene ou supressor tumoral do WT1 parece ser resultado de como a célula em um determinado estágio de desenvolvimento, responde a perturbações na expressão de outros genes. Sua função parece estar mais relacionada ao contexto e tipo celular, status de diferenciação, presença de outros genes alterados, e microambiente (Huff, 2011). Os estudos têm focado em seu papel na tumorigênese cerebral, onde WT1 parece exercer um papel oncogênico nos tumores mesmo que eles não expressem normalmente este gene e nem mutações tenham sido encontradas no gene $(184,185)$. Dentre outros pontos curiosos sobre este gene incluem o fato de ele estar localizado em uma região de imprinting (186) e apresentar papel importante no desenvolvimento de neurônios olfatórios e da retina $(187,188)$.

Não há relatos de outros pacientes com alteração nesse segmento e anomalia do CC no DECIPHER. Portanto, mais estudos devem ser conduzidos para 
investigar o papel exato de CNV nestes dois genes durante a formação do CC na embriogênese.

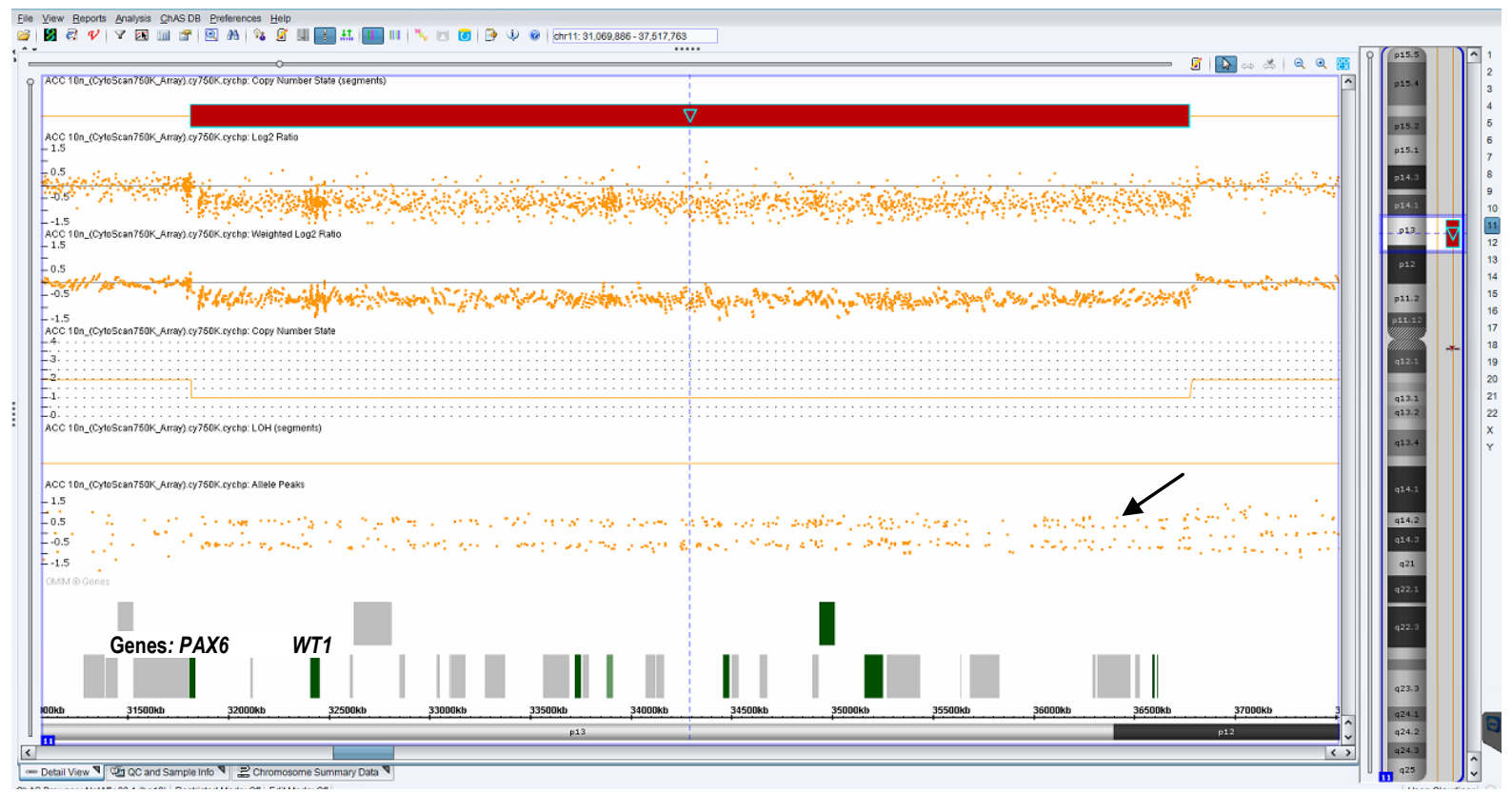

Figura 8. Visualização da microdeleção (barra na parte superior) encontrada pela CMA, por meio do programa de análises ChAS versão 3.0 (Affymetrix, EUA), na paciente ACC10. Esta CNV possui um tamanho de cerca de 4,9 Mb na região citogenômica de 11p13-12 (31,813,872-36,773,780), e envolve os genes WT1 e PAX6, que são sugeridos terem correlação com as anomalias no desenvolvimento do CC desta paciente. Os pontos em cor laranja na parte central da figura representam as sondas não polimórficas e as sondas específicas para os SNPs (indicado pela seta), hibridadas no chip da plataforma CytoScan 750k Array (Affymetrix, EUA). 


\subsubsection{Paciente ACC11}

O paciente ACC11 é um menino de 1 ano e 4 meses com DCC visualizada por TC de crânio, apresenta cariótipo alterado 46,XY(del21)(q22), com quase nenhuma malformação descrita além de discreto grau de colpocefalia, sugerindo um quadro clínico de malformação do CC isolada.

O exame de CMA revelou uma deleção de novo de $7,3 \mathrm{Mb}$ de comprimento no cromossomo 21q11.2q21.1 (16,115,678-23,502,590) envolvendo 19 genes na região (Figura 9). Dentre os genes encontrados nesta CNV que permiotem inferir dobresonreelação com o fenótipo de ACC parcial sugeriu-se a possibilidade de NCAM2 estar envolvido na malformação calosal.

O gene Neural cell adhesion molecules 2 (NCAM2/OCAM/RNCAM) (OMIM 602040) é um parálogo do gene NCAM1 e faz parte de uma família de mediadores de adesão celular que são ubiquamente expressos no sistema nervoso. Além de mediarem a adesão celular, estão envolvidos em amplos processos celulares incluindo sobrevivência, migração e diferenciação de neurônios, formação e plasticidade das sinapses $(189,190)$. NCAM2, por sua vez, está envolvido em processos de estimulação de neurite, facilitação dendrítica e compartimentalização axonal. Um estudo apontou sua importância na organização de axônios e dendritos no sistema olfatório (191).

Por ser considerado um gene sensível à dosagem, e apesar de estar localizado fora da região crítica do cromossomo 21 que tem sido proposta como candidata à Síndrome de Down, estudo de Makino e McLysaght (192) sugeriu que o aumento na expressão de NCAM2 como resultado da trissomia do cromossomo 21 poderia causar efeitos dosagem-dependentes no desenvolvimento. Estudos de GWAS encontraram uma forte associação de NCAM2 com o autismo (193) e a doença de Alzheimer (194).

Além disso, a região deletada em ACC11 encontra sobreposição com outras deleções depositadas no DECIPHER (\#285987). E mais, em estudo recente, Petit e colaboradores (195) realizaram a descrição das alterações encontradas por CMA em três pacientes com desordens do neurodesenvolvimento, sem especificar a presença de ACC, com deleções envolvendo o gene NCAM2, onde sugeriu também a patogenicidade das CNVs envolvendo NCAM2 e a necessidade de se investigar 
mais sobre a sua correlação com CNVs que afetam o desenvolvimento neuropsicomotor.

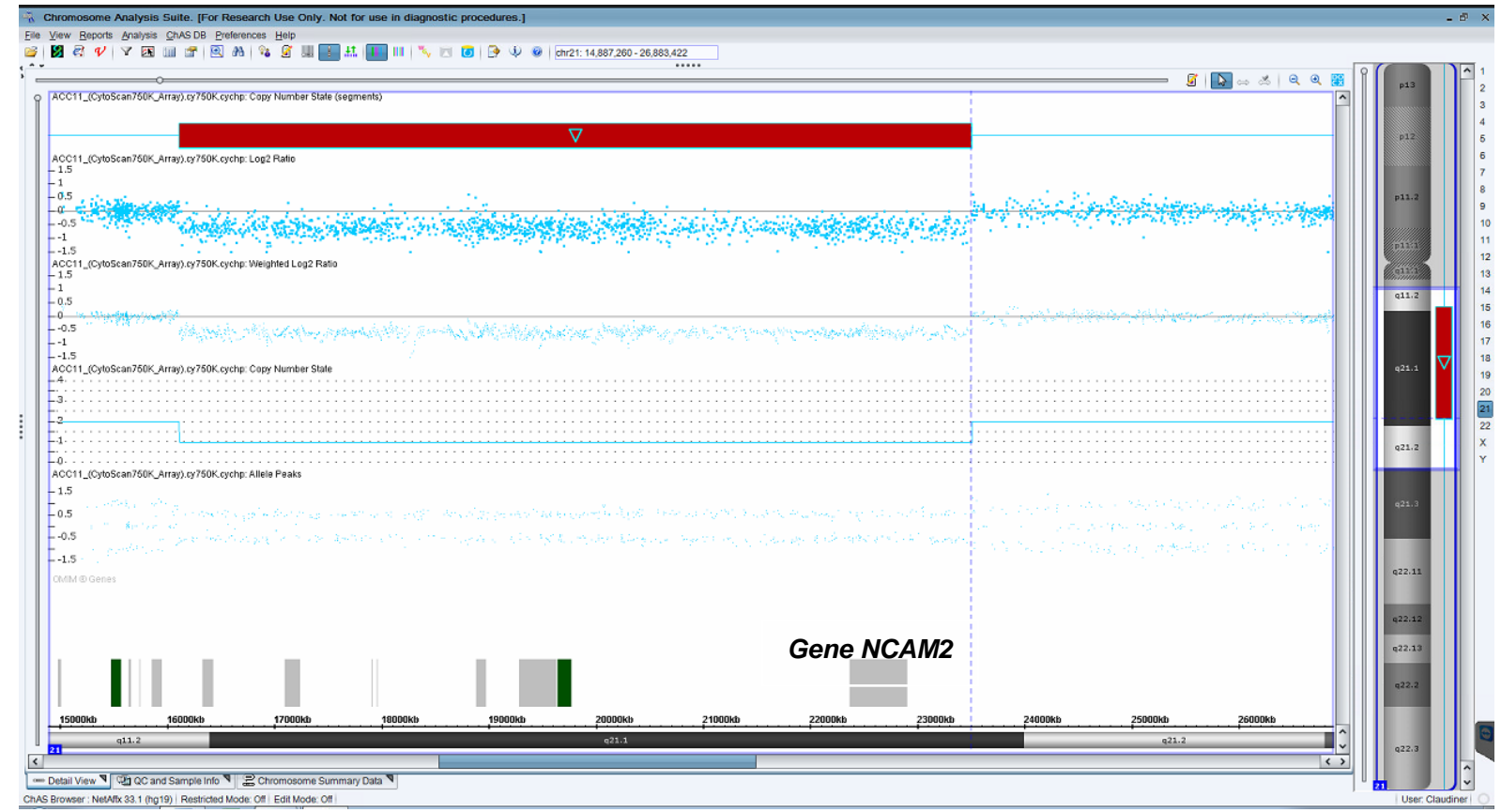

Figura 9. Exame de CMA no paciente ACC11, visualizado pelo software ChAS versão 3.0 (Affymetrix, EUA), mostrando a microdeleção (barra vermelha na parte superior) que afeta $7,3 \mathrm{Mb}$ da região citogenômica de 21q11.2q21.1 (16,115,678-23,502,590), onde está o gene NCAM2, candidato a ser o principal causador da anomalia no desenvolvimento do CC deste paciente. Análise realizada com a plataforma CytoScan 750k Array (Affymetrix, EUA). 


\subsubsection{Paciente ACC20}

A paciente ACC20, com idade de 2 anos e 9 meses, com DCC observada ao RM de encéfalo, cariótipo 46,XX, e com quadro sindrômico de ADNPM (poucos movimentos fetais, hipotonia, dificuldade para sugar o seio materno, não segura objetos, não engantinha, atraso na fala), crises convulsivas à partir do $3^{\circ}$ mês de vida, dismorfias faciais (hipoplasia de face média, proptose ocular, baixa implantação das orelhas), baixa estatura, e suspeita clínica de Síndrome de WolfHirschhorn ou WHS (MIM \#194190).

O exame por CMA revelou a existência de uma deleção de 5,4 Mb em $4 p 16.3$ $(68,345-5,509,835)$ afetando 78 genes (Figura 10). Esta região é conhecida como região crítica para WHS onde a haploinsuficiência dos genes WHSC1 (presente em todas as deleções, OMIM: 602952) e LETM1 (OMIM: 604407) é considerada a principal responsável pela patogênese da Síndrome. Entretanto, estudos recentes evidenciam que somente a deleção de WHSC1 não seria suficiente para o fenótipo completo, que inclui DI, epilepsia, atraso no crescimento e disgenesia craniofacial (196).

Alguns estudos atribuem anomalias no desenvolvimento compatíveis com os fenótipos observados em WHS às alterações envolvendo o gene WHSC1, que codifica uma proteína regulatória nuclear que possui atividade de metiltransferase, responsável por modificações de histonas durante a regulação dos processos transcricionais $(197,198)$. É importante lembrar que alterações na dosagem gênica de fatores modificadores de histonas são conhecidas causadores de deficiências intelectuais (198). Esta função de WHSC1 implica em vários processos biológicos que envolvem o desenvolvimento precoce tais como a sinalização por citocinas, a resposta aos danos no DNA e alguns tipos de recombinação (196).

Estudos em ratos mostraram que o efeito da deleção no gene resulta em problemas no crescimento, malformações craniofaciais e defeitos de fusão na linha média (199). E mais, defeitos na estrutura do sistema nervoso central foram relatados em $80 \%$ dos indivíduos afetados por WHS (200). Dentre esses efeitos, com incidência variando entre $30 \%-70 \%$, incluem defeitos relacionados com a fusão da linha média, tais como falha no couro cabeludo, ACC, lábio/fenda palatina, defeitos cardíacos, e malformações do trato urinário $(200,201)$. Em outro estudo, observaram afilamento do $\mathrm{CC}$ associado com diminuição difusa do volume da 
substância branca, aumento dos ventrículos laterais, atrofia cortical/subcortical, e diversas alterações cerebelares (202). Vale lembrar que afilamento do CC é um indício de alteração do desenvolvimento e maturação da substância branca.

Outro ponto a ser considerado é que durante o fechamento da linha média formam-se estruturas gliais múltiplas que são essenciais para a formação do CC (203). Uma dessas estruturas, a ponte glial, se localiza na parte ventral do CC evitando que os axônios calosais se dirijam para a parte ventral ao invés de cruzarem a linha média (204). Estudos sobre a orientação axonal por esta e outras estruturas gliais na linha média são essenciais para o entendimento da formação da ACC. Com tudo isso e considerando a CNV e o fenótipo sindrômico da paciente ACC20, sugere-se a realização de estudos mais aprofundados para verificar se a deleção do gene WHSC1 apresenta uma correlação direta ou indireta com os mecanismos que contribuem para a alteração da linha média e, consequentemente, da ACC.

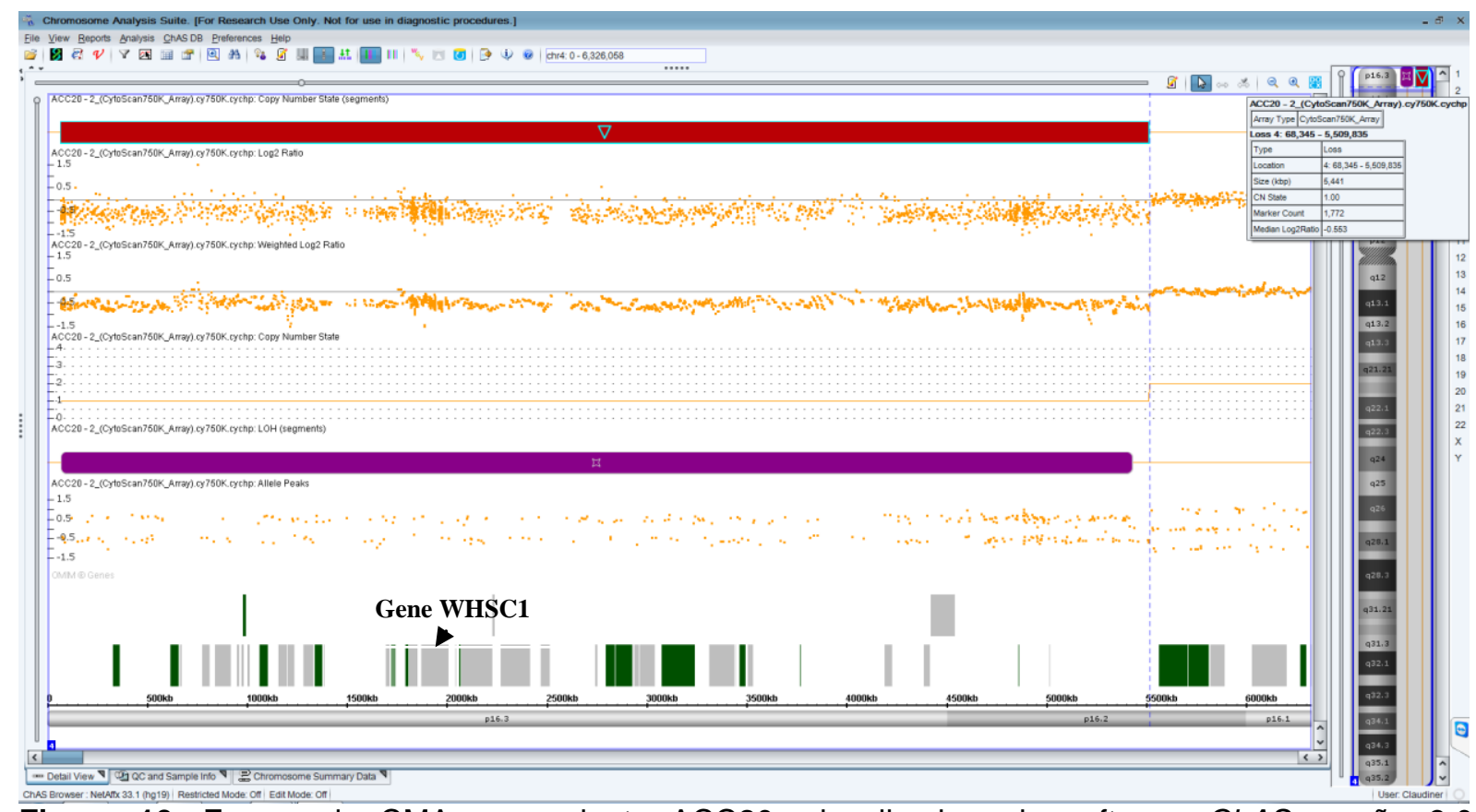

Figura 10. Exame de CMA na paciente ACC20, visualizado pelo software ChAS versão 3.0 (Affymetrix, EUA), mostrando a deleção (barra vermelha na parte superior) afetando $5,4 \mathrm{Mb}$ da região citogenômica de $4 p$ del16.3 (68,345 - 5,509,835), na qual o gene WHSC1, relacionado com a Síndrome de Wolf-Hirschhorn, sugere envolvimento nas alterações do desenvolvimento do CC. Análise realizada com a plataforma CytoScan 750k Array (Affymetrix, EUA). 


\subsubsection{Paciente ACC22}

O paciente ACC22, é uma criança de seis meses que, além da DCC visualizada pela $\mathrm{RMN}$, apresenta uma série de malformações ao exame físico tais como dismorfias faciais (hipertricose facial, pinçamento bifrontal, fendas palpebrais oblíquas para baixa, dorso nasal deprimido, lábio superior fino, dentes supranumerários, palato ogival, narinas antevertidas, retrognatia, orelhas rodas posteriormente), anomalias nos membros (membros superiores semifletidos e inferiores cruzados, sobreposição de $1^{\circ}$ sobre $3^{\circ}$ dedos das mãos, encurtamento do $5^{\circ}$ dedo), graves anomalias gastrointestinais (distúrbios de deglutição, abdomen agudo obstrutivo, má rotação intestinal, atresia ileal e de cólon), hipertrigliceridemia, hipercalemia, e teve parada cardiorrespiratória ao nascimento. A suspeita de erro inato do metabolismo não se confirmou aos exames.

Os exames da CMA registraram uma deleção de novo de 3,4 Mb na região citogenômica de 8q12.1 (56,523,670-59,961,677) afetando 15 genes com morbidades correlacionadas no OMIM. São eles e seus respectivos registros no OMIM: TGS1 (606461), LYN (165120), RPS20 (603682), MOS (190060), PLAG1 (603026), CHCHD7 (611238), SDR16C5 (608989), PENK (131330), IMPAD1 (614010), FAM110B (611394), UBXN2B (610686), CYP7A1 (118455), SDCBP (602217), NSMAF (603043) e TOX (606863). Nenhum dos genes apresentou uma correlação direta com qualquer etapa que descrita do desenvolvimento do $\mathrm{CC}$, embora os genes PLAG1, PENK e TOX apresentem papéis em processos celulares elementares e expressão no tecido neural.

Embora existam três indivíduos descritos no DECIPHER com deleções que abarcam esta região, nenhum apresenta alteração do CC descrita nas informações disponíveis. Apesar das evidências documentadas não relatarem correlação clara da CNV com anomalias do CC, o grande tamanho e quantidade de genes afetados incluídos no fragmento sugerem uma correlação patogênica com as alterações fenotípicas do paciente. 


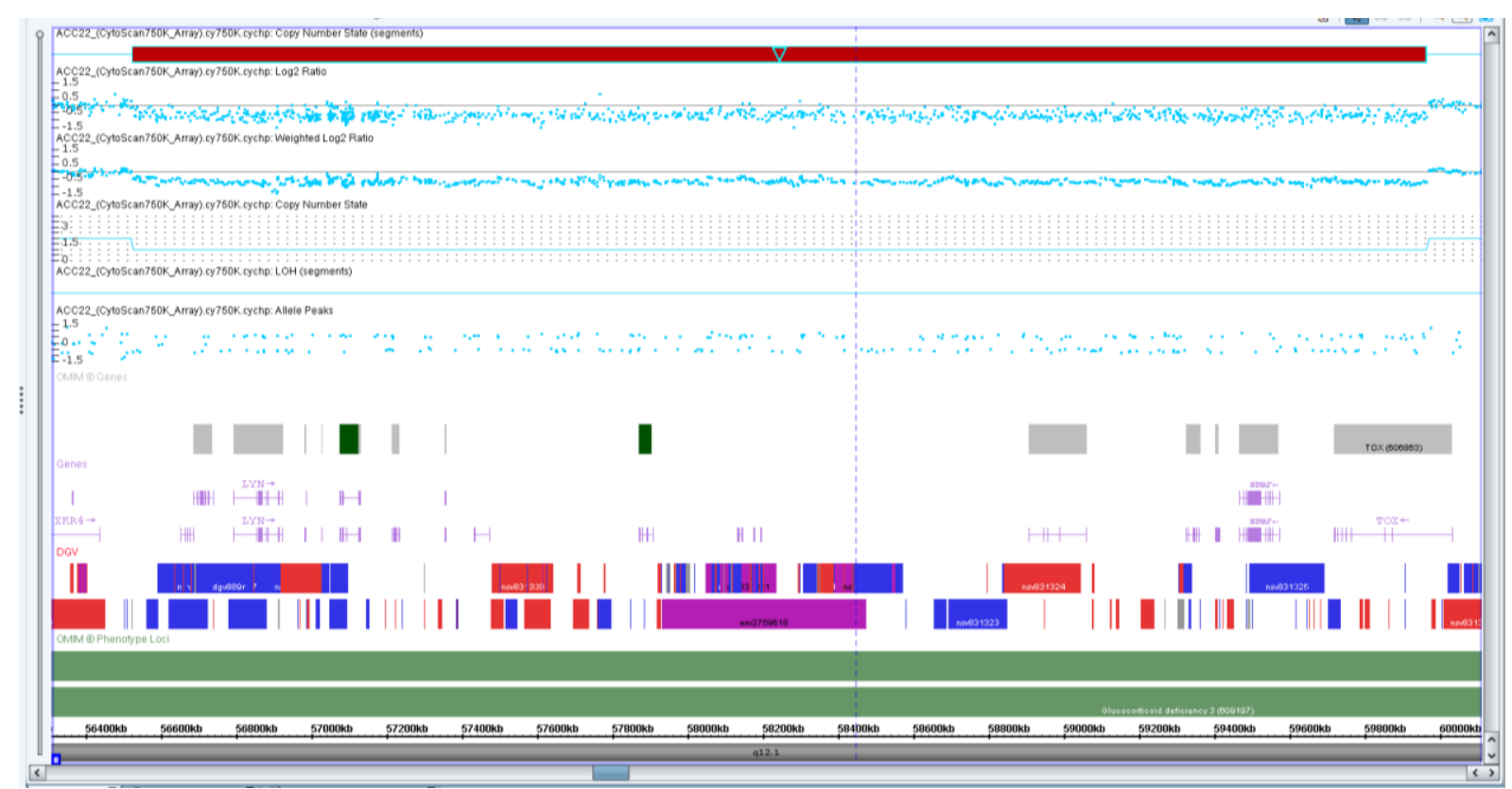

Figura 11. Exame de CMA no paciente ACC22, visualizado pelo ChAS versão 3.0 (Affymetrix, EUA), mostrando a deleção (barra vermelha na parte superior) que possui aproximadamente $3,4 \mathrm{Mb}$ na região citogenômica de 8q12.1 (56,523,670-59,961,677). Análise realizada com a plataforma CytoScan 750k Array (Affymetrix, EUA). 


\subsubsection{Paciente ACC31}

A paciente ACC31, com 2 meses de idade, tinha uma quadro clínico sindrômico bastante grave, que incluía ACC completa visualizada por 2 USTF realizadas em momentos distintos, exame de translucência nucal alterado, necessitou de reanimação após o parto, apresentou cefalohematoma parietal ao $3^{\circ}$ dia de vida (d.d.v), atresia das vias biliares intra-hepáticas, macrocrania, dismorfias faciais (disjunção de sutura sagital, baixa implantação capilar com bico de viúva, hipertelorismo ocular, fendas palpebrais obliquas para cima, orelhas com sobredobramento em hélice e rotação posterior, fosseta pré-auricular, macrostomia e retrognatia), atresia intestinal e anomalias nos membros (mãos com aracnodactilia, pregas palmares irregulares, pés tortos).

O exame de CMA revelou uma duplicação de 49,3 Mb cobrindo todo o braço curto do cromossomo em 5p15.33q11.1 (113,576-49,441,945), afetando 187 genes no total dos quais 101 apresentam fenótipo no OMIM (Figura 12). Após este resultado realizou-se o carótipo por banda $G$ que não apenas confirmou a alteração encontrada na CMA como trouxe novas informações ao registrar a presença de translocação não balanceada entre os cromossomos 5 e 15, conforme o resultado 46,XX,der(5)t(5;15)(q1?;q1?). A RN evoluiu para óbito após algumas semanas internada em UTI neonatal.

A duplicação do cromossomo $5 p$ é uma anomalia cromossômica que diversos casos têm sido relatados tanto com a duplicação do cromossomo 5 parcial quanto completa. A trissomia parcial resulta de uma translocação ou inversão parental (205). As principais manifestações clínicas da trissomia $5 p$ são dismorfias faciais, anormalidades nos membros, defeitos cardíacos, malformações renais e intestinais, e DI. Outro típico achado está representado pela hidrocefalia e ventriculomegalia (205).

Embora o que chame atenção seja uma síndrome provocada por alterações de grande tamanho, observações dos quadros clínicos sugerem que esta região relatada contenha genes que exerçam função no desenvolvimento SNC (206), tais como NSUN2 (OMIM 610916) que codifica uma metiltransferase e cuja disfunção está associada à uma forma de DI provocada por herança autossômica recessiva ( MIM\# 611091). E mais, duplicações na região 5p13.3-13.1, que está dentro da 
região afetada na paciente $A C C 31$, foram correlacionadas como região crítica para ACC por O'Driscoll e colaboradores (61).

Mais estudos precisam ser feitos e mais pacientes com alterações no CC e esta área afetada, de cerca de $13 \mathrm{Mb}$, precisam ser descritos para permitir restringir o tamanho da região crítica e, se possível, elencar os genes mais importantes envolvidos nestas alterações do desenvolvimento do CC.

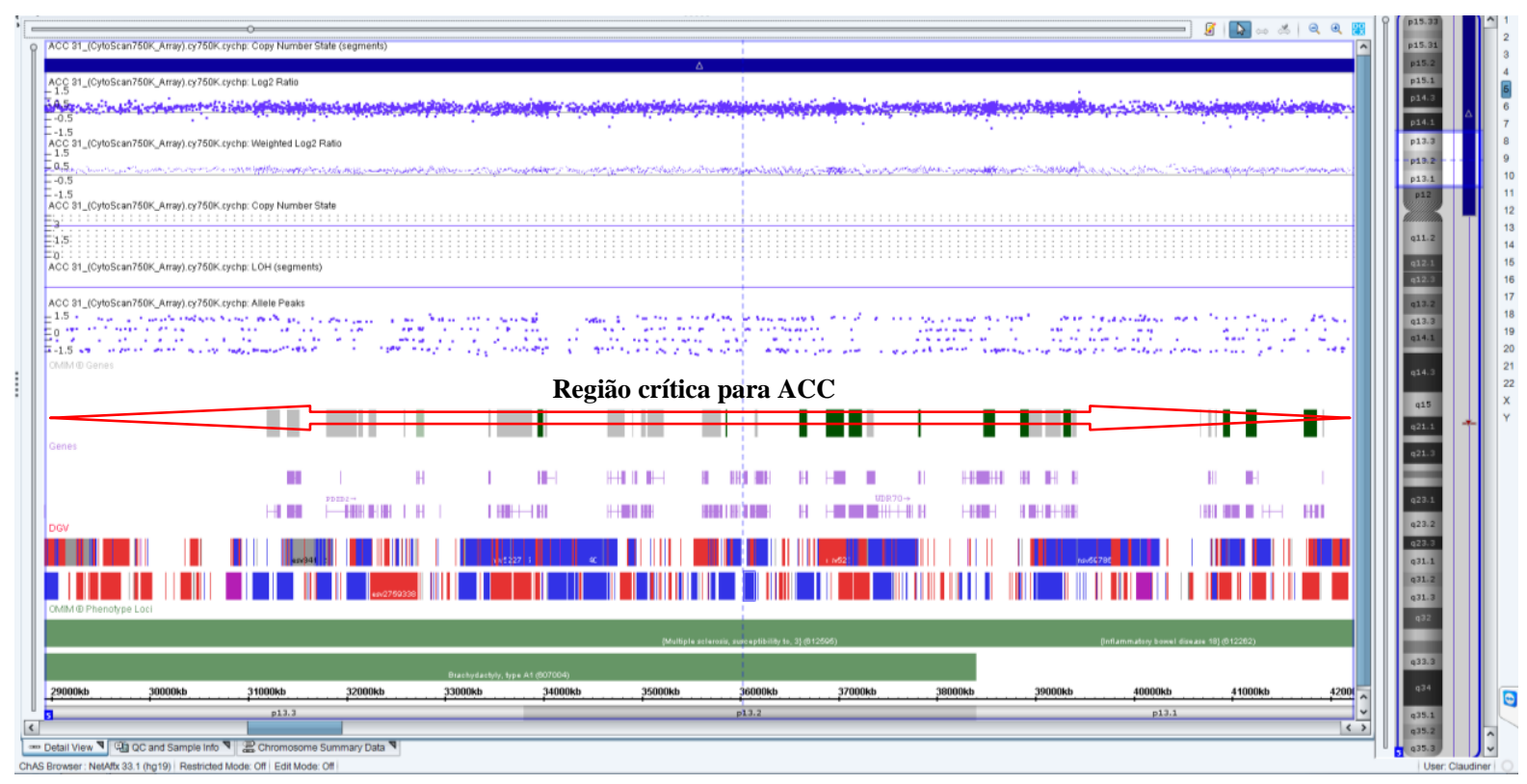

Figura 12. Exame de CMA na paciente ACC31, visualizado pelo ChAS versão 3.0 (Affymetrix, EUA), mostrando a duplicação (barra azul na parte superior) afetando 49,3 Mb da região citogenômica de 5p15.33q11.1 (113,576-49,441,945), e evidenciando a região descrita por O'Driscoll e colaboradores (61) como crítica para alterações no CC. Análise realizada com a plataforma CytoScan 750k Array (Affymetrix, EUA). 


\subsubsection{Paciente ACC36}

O paciente ACC36, 7 meses de idade, com DCC visualizada por USTF, teve relatado no prontuário uso de álcool e tabagismo por parte da mãe durante a gestação. A criança não chorou ao nascer, apresenta dismorfias faciais (hipertelorismo ocular, epicanto invertido, orelhas grandes e proeminentes rodadas posteriormente, fenda palatina, retrognatia, implantação alta dos cabelos), e alterações de membros (clinodactilia nos 5ำ dedos das mãos, edema de membros inferiores).

O exame de CMA detectou uma duplicação de 21,4 Mb em 3p24-3p26.1 (61,891- 21,533,109) e uma deleção de 4.4 Mb em 10q26.3 (130,982,035135,426,386) abrangendo 6.404 e 1.113 genes, respectivamente (Figura 13).

A sugestão citogenética é de que se trata de uma $t(3 ; 10)$ e a suspeita clínica de Síndrome Alcoólica Fetal (FAS) ganhou força quando se verificou o histórico do caso. Apesar disso, se as alterações do CC apresentarem envolvimento genético, a análise sugere que os genes CRBN (OMIM: 609262) e SETD5 (OMIM: 615743) encontrados no seguimento afetado de poderiam ter alguma influência sobre a formação estrutural do CC. O primeiro parece ter envolvimento no desenvolvimento neural (207). O segundo codifica uma metiltransferase que é amplamente conservada evolutivamente entre os mamíferos, sugerindo seu papel importante, embora pouca se conheça sobre seu papel no cérebro fetal e adulto (208).

De toda forma, é importante notar que fatores ambientais podem contribuir de forma bem clara para a ACC. Apesar de que se conhece menos sobre estes mecanismos do que aqueles que envolvem fatores genéticos. A exposição ao álcool in útero diminui a gliogênese (209) e as interações gliais com neurônios (210), processo que são vitais para o desenvolvimento do CC (211). Além disso, estudos sugerem que o etanol perturba a transcrição e função bioquímica do gene L1CAM (OMIM: 308840). A incidência de ACC completa em pacientes com FAS é de aproximadamente $6,8 \%$, com uma incidência ainda maior para os casos de disgenesia ou hipoplasia do CC (60). 


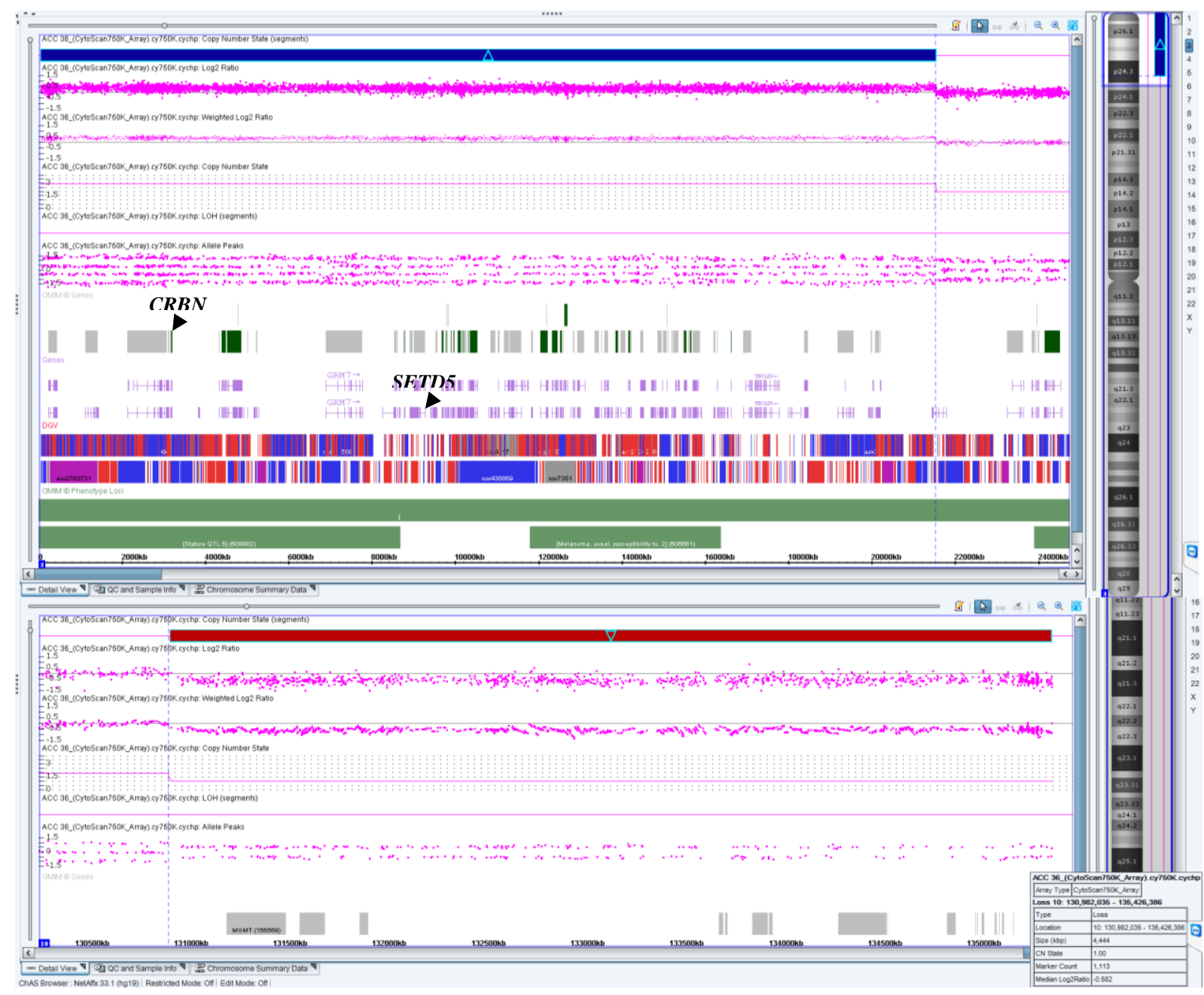

Figura 13. Representação gráfica, visualizado pelo ChAS versão 3.0 (Affymetrix, EUA), encontrada na CMA da paciente ACC36, com uma duplicação (barra azul na imagem superior) nba região citogenômica de 3p24.3p26.1 (61,891-21,533,109) afetando 21,4 Mb, onde se encontram os genes CRBN e SETD5 com possibilidade de impacto no desenvolvimento do CC; e uma deleção (barra vermelha na imagem inferior) em 10q26.3 (130,982,035-135,426,386) cobrindo 4.4 Mb. Análise realizada com a plataforma CytoScan $750 k$ Array (Affymetrix, EUA). 


\subsubsection{Paciente ACC37}

O paciente ACC37 com um mês de vida, ACC completa visualizada por TC de crânio, apresenta um quadro grave com anomalias faciais (ausência dos globos oculares, fendas palpebrais levemente obliquas pra cima), hipotonia, hipertricose frontal em face e droso, pescoço alado, anomalias em membros (ausência de polegares, dedos da mão esquerda espatulados, pés em "mata borrão"), pectus excavatum, anomalias cardíacas (ventriculomegalia), mielomenigocele sacral rôta, genitália ambígua e ânus imperfurado com suspeita clínica de Síndrome de Fryns (MIM \#229850). O paciente evoluiu para óbito no período neonatal.

O exame da CMA realizado detectou uma duplicação no cromossomo 3q26.33q29 (178,453,636-197,861,444) de 19,3 Mb afetando 183 genes (Figura 14a), e uma deleção no cromossomo 13q31.1q34 (83,591,362-114,970,605) com 31,3 Mb afetando, por sua vez, 134 genes (Figura 14b). Após esta constatação realizou-se a análise por cariótipo por banda G que registrou o cariótipo 46,XY, der (13) (Figura 14c). Por outro lado, durante a investigação da origem destas alterações verificou-se que a CMA realizada com os pais não registrou as CNVs encontradas no recémnascido, mas o cariótipo acusou uma translocação balanceada 3;13 na mãe: 46,XX $\mathrm{t}(3 ; 13)$ (q26;q31). Informações no prontuário davam nota de que a mãe tinha histórico de três abortamentos e dois RNs polimalformados prévios.

A região duplicada de 3q26 contempla o gene SOX2 (OMIM: 184429) cuja expressão produz fatores de transcrição que mantêm as populações de células glia radiais intermediando a diferenciação de neurônios a partir de células progenitoras (212). Mutação em SOX2 humano não gera a disgenesia cortical que produz fenótipos neurológicos graves em modelos animais. Sendo assim, os pacientes com mutações envolvendo SOX2 normalmente apresentam hipoplasia colossal mais comumente que ACC parcial ou total (179). O paciente ACC37, embora tenha uma CNV grande que envolve diversos genes, sugere que a perturbação no locus onde se encontra esse gene pode ser dose sensível para justificar a presença de ACC total ao invés de um fenótipo mais brando.

Outro gene afetado neste indivíduo foi ZIC2 (OMIM: 603073) com a deleção de 13q31.1, pois pode afetar um gene que está envolvido diretamente com formação da holoprosencefalia e de anomalias do CC (213). Chabchoub e colaboradores (214) 
evidenciaram fenótipos faciais específicos para deleção de ZIC2 diferente do que surge com as mutações de ponto.

Por outro lado, podemos observar que uma espécie de monossomia funcional e estrutural do cromossomo $13 \mathrm{q}$, onde a maioria dos indivíduos apresentam deleções do braço longo do cromossomo 13, o qual inclui o gene NALCN (OMIM: 611549). Os fenótipos dos pacientes variam, mas as malformações graves envolvem o atraso no crescimento com microcefalia, dismorfias fácil, anomalias congênitas cardíacas, do cérebro e dos rins (215). Nos indivíduos com fenótipo leve apresentam dismorfias menores, DI, e atraso no crescimento. Estudos já correlacionaram a gravidade do fenótipo com a extensão da deleção. Deleções que afetam a região onde contem o gene NALCN são consideradas crítica para os fenótipos envolvendo malformações cardíacas, defeitos do tubo neural e do sistema nervoso incluindo ACC, DI, e dismorfias faciais (216-218).

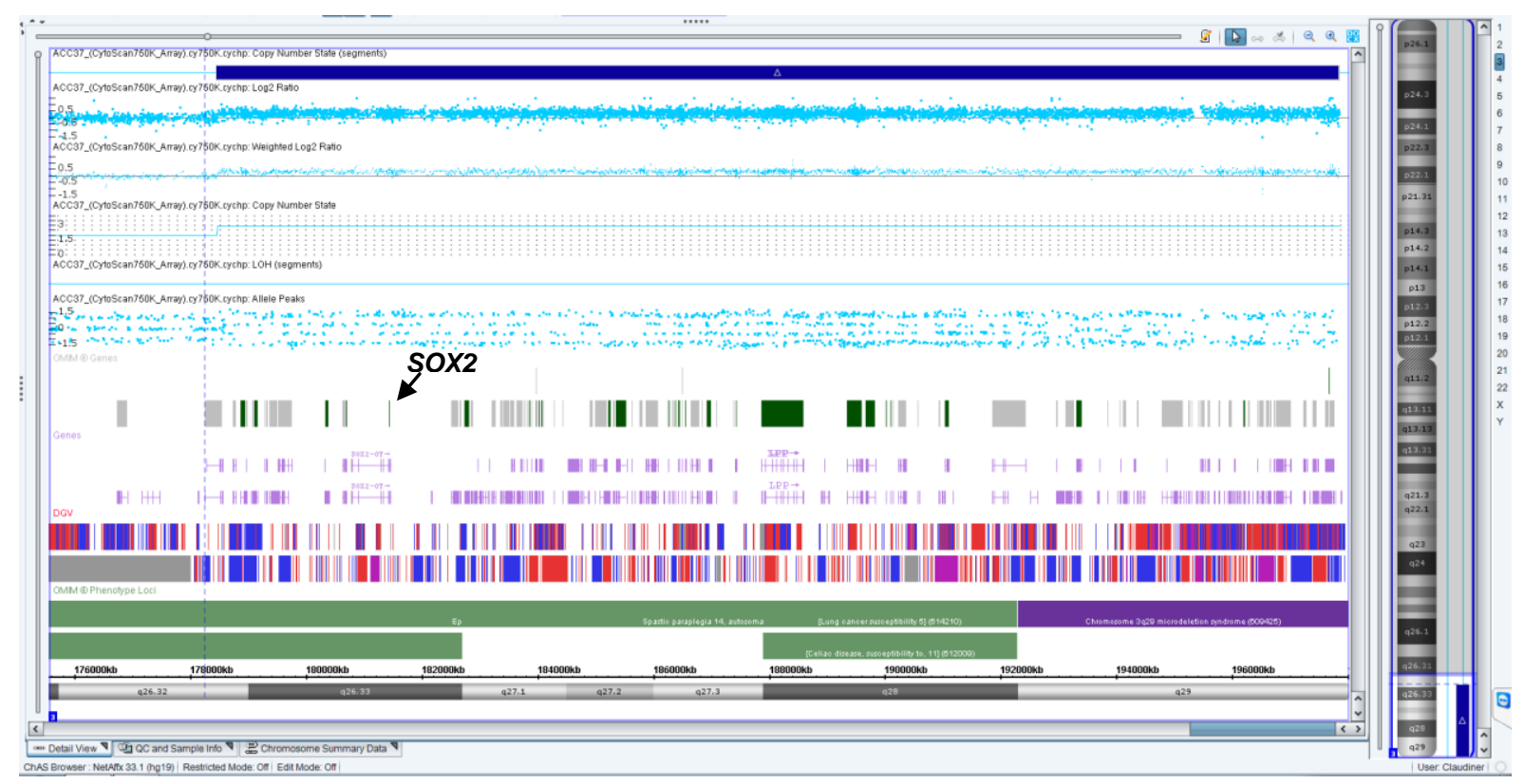

(a) 


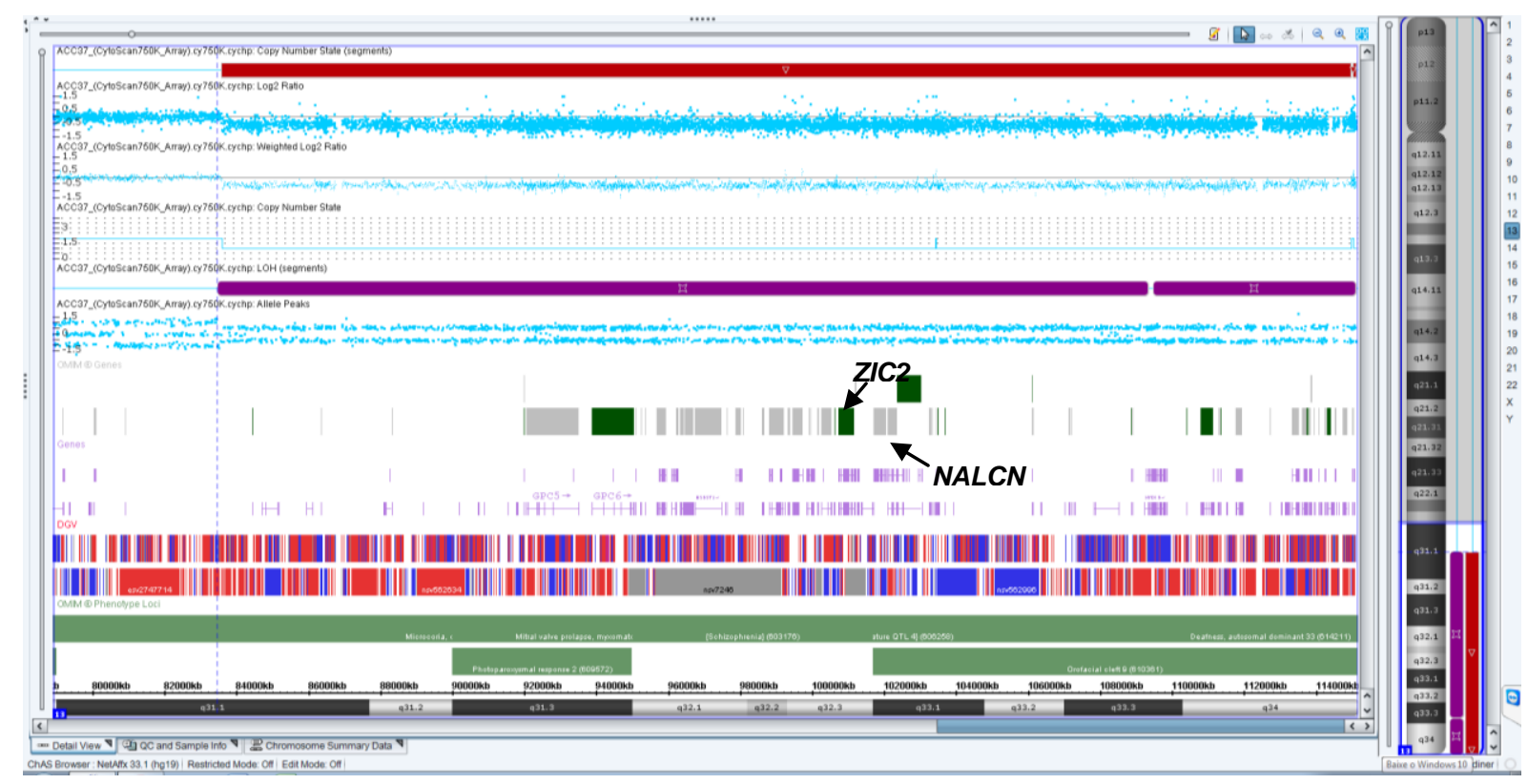

(b)

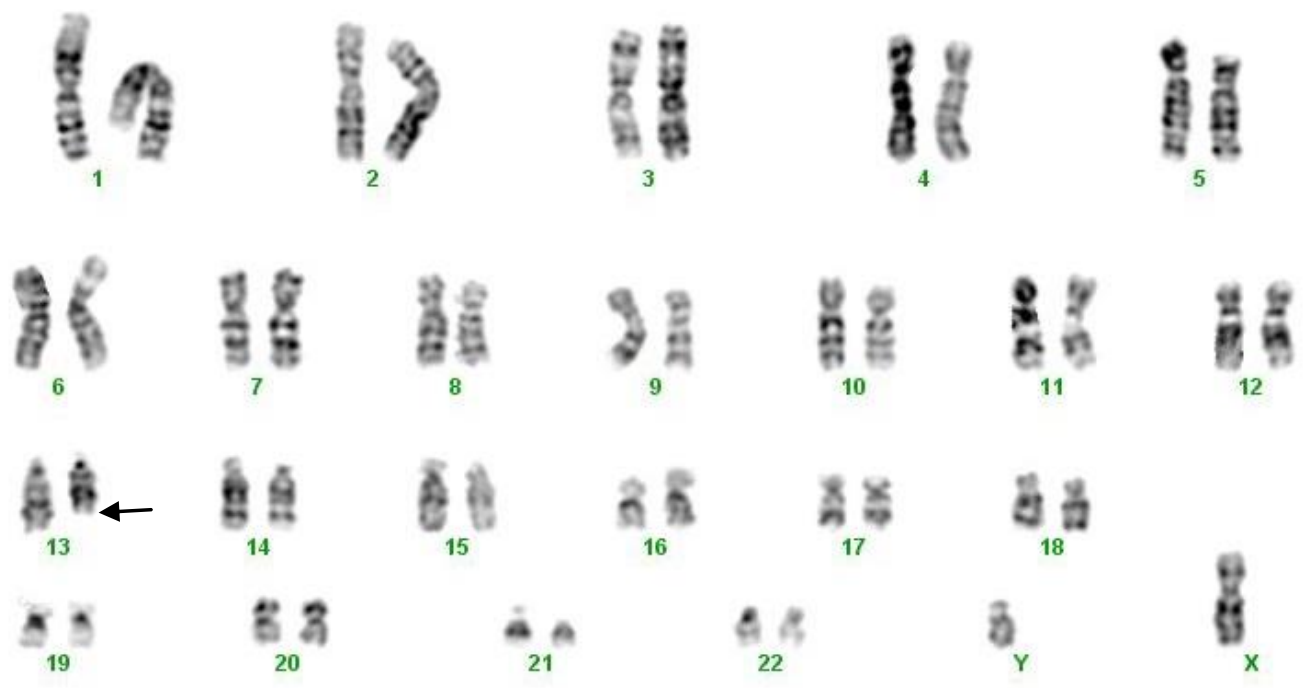

(c)

Figura 14. (a) Exame de CMA na paciente ACC37, visualizado pelo ChAS versão 3.0 (Affymetrix, EUA), mostrando uma duplicação (barra azul na parte superior) na região citogenômica de 3q26.33q29 (178,453,636-197,861,444) com tamanho de 19,3 Mb evidenciando o gene SOX2 sugerido como responsável pela alteração do CC na paciente; (b) e da deleção (barra vermelha na parte superior) em 13q31.1q34 (83,591,362-114,970,605) cobrindo 31,3 Mb evidenciando os genes ZIC2 e NALCN, candidatos a terem correlação com a alterações do desenvolvimeto do $\mathrm{CC}$. Exame realizado na plataforma CytoScan 750k Array (Affymetrix, EUA). Posteriormente, o resultado do cariótipo por banda $G$ revelou a existência de uma translocação balanceada entre os cromossomos 3 e 13. (c) Cariograma da paciente ACC37 produzido com análise de 30 metáfases, obtidas de cultura temporária de linfócitos do sangue periférico, coradas por bandeamento $\mathrm{G}$, resolução de 300 bandas, evidenciando com a seta o cromossomo der(13). 


\subsubsection{Paciente ACC41}

A paciente ACC41, com mais de 12 anos de idade, possui diagnóstico de ACC completa que foi visualizada por TC de encéfalo, cariótipo alterado $46, X, \operatorname{del}(X)(p 22.1)$, apresenta ADNPM grave, atraso na fala, anomalias faciais (braquicefalia, face alongada, baixa implantação capilar, microftalmia, assimetria ocular, opacificação de córnea bilateral, implantação baixa das orelhas), anomalias de membros e tronco (clinodactilia nos $5^{\circ}$ dedos das mãos e sindactila bilateral nos pés) e suspeita clínica para a Síndrome de MIDAS (MIM \#309801).

O exame da CMA demonstrou uma grande deleção de 13,4 Mb em Xp22.2p22.33 (168,551-13,577,093) que abrange um total de 66 genes (Figura 15). Normalmente 0 cromossomo $X$ apresenta dificuldades para interpretação requerendo critérios diferentes das CNVs autossômicas. Neste caso, o grande tamanho do fragmento deletado e, por consequência, o grande número de genes afetados, determinaram a correlação patogênica para as alterações clínicas apresentadas pela paciente. De toda forma, estimam que o $\mathrm{X}$ seja responsável por $10 \%$ de todas as CNVs patogênicas em casos de DI ligada ao $X$, das quais $80 \%$ a 90\% seriam herdadas do lado materno (219). Em indivíduos do sexo feminino, as consequências clínicas de uma CNV ligada ao $X$ podem variar amplamente entre os indivíduos devido à inativação do $X$. E ainda, o padrão de inativação do $X$ pode variar entre diferentes tipos de células.

No caso da paciente ACC41 seria necessário realizar a CMA dos genitores para se confirmar a origem da alteração. Se a mesma CNV for detectada também no pai da paciente, a probabilidade da CNV ser benigna é grande. Se a CNV for herdada do lado materno, então a relevância clínica não será confirmada até que sejam feitos estudos adicionais de inativação do $X$ alcançando até outros familiares maternos. Quando nenhum indivíduo masculino portar a mesma CNV encontrada, então a patogenicidade da CNV pode ser sugerida (220).

À parte disso, temos que a heterozigose do gene HCCS (OMIM: 300056), especificamente nesta região do X, em meninas com Síndrome da Microftalmia (MIM \#309801), já foi descrita para indivíduos com ACC $(221,222)$, sugerindo assim uma forte correlação com o caso de ACC41. Gene que devido à sua participação no metabolismo oxidativo (223) e à haploinsuficiência, foi sugerido ter papel essencial nos fenótipos destes pacientes. Sendo assim, outros estudos precisam ser 
realizados no sentido de se investigar a contribuição desta alteração para o desenvolvimento do CC.

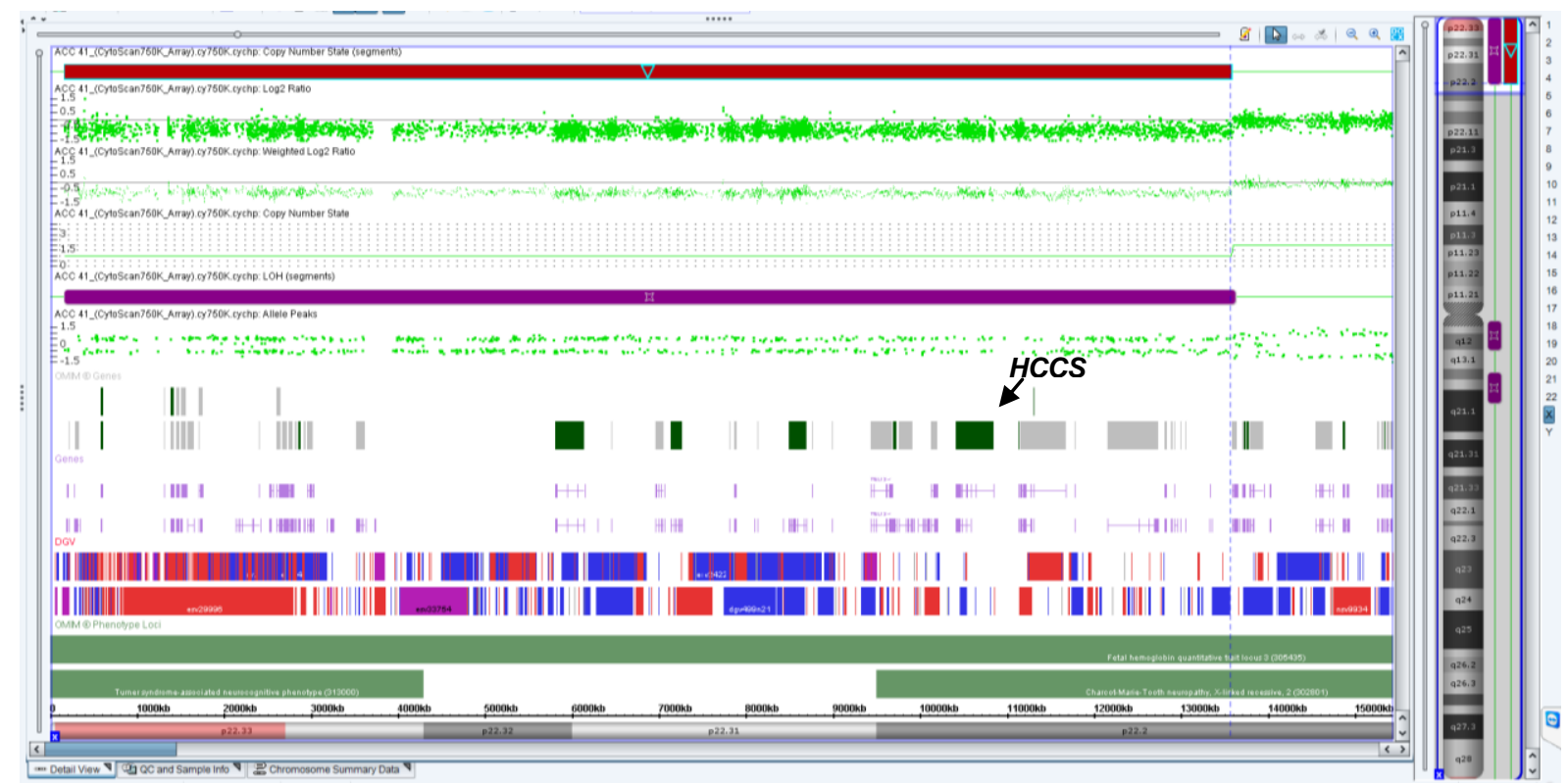

Figura 15. Exame de CMA na paciente ACC41, visualizado pelo ChAS versão 3.0 (Affymetrix, EUA), mostrando a deleção (barra vermelha na parte superior) afetando 13,4 Mb da região citogenômica de Xp22.2-p22.33 (168,551-13,577,093), na qual a permite correlacionar o gene HCCS como o provável responsável malformações do $\mathrm{CC}$ na paciente. Exame realizado na plataforma CytoScan 750k Array (Affymetrix, EUA). 


\subsubsection{Paciente ACC42}

A paciente ACC42, de 1 ano e 10 meses, possui hipoplasia do CC visualizada por TC de encéfalo, cariótipo 46,XX(9qh+), apresentando ADNPM, dificuldade na ingestão de alimentos sólidos, dismorfias faciais (microcefalia, hipertelorismo ocular, base nasal larga, sulco nasolabial apagado), pescoço curto, anomalias nas mãos e nos pés, e fosseta sacral.

O exame de CMA revelou uma microdeleção em 6 q27 (168,211,952170,914,297), com tamanho de 2,7 Mb e afetando 22 genes no total (Figura 16). Apesar de ser uma CNV herdada do lado paterno, esta região apresenta o gene ERMARD (OMIM: 615532), também conhecido por C6orf70, que foi descrito em um estudo com 155 pacientes, dos quais 12 apresentavam deleções de 6q27 e alterações no CC, dentre outras dismorfias (224). Estudo recente realizado por Peddibhotla e colaboradores (225) evidenciou também a importância da deleção em 6q27 como causadora de malformações cerebrais incluindo ACC. Eles registraram distúrbios de migração neuronal em 9 dos 12 pacientes analisados, incluindo heterotopia nodular periventricular e ACC associados à haploinsuficiência de ERMARD. No DECIPHER existem dois registros ( $\mathrm{n}-253900$ e 292073) com segmentos de $6 \mathrm{q} 27$ deletados e que, apesar de serem maiores que o da paciente ACC42, ambos apresentam hipoplasia de CC.

Diante de tais circunstâncias e dos relatos na literatura, o quadro de alterações cerebrais da paciente ACC42 deriva, provavelmente, da deleção de $6 \mathrm{q} 27$ e o gene ERMARD é o candidato mais indicado para ser a causa de alterações no desenvolvimento do CC. 


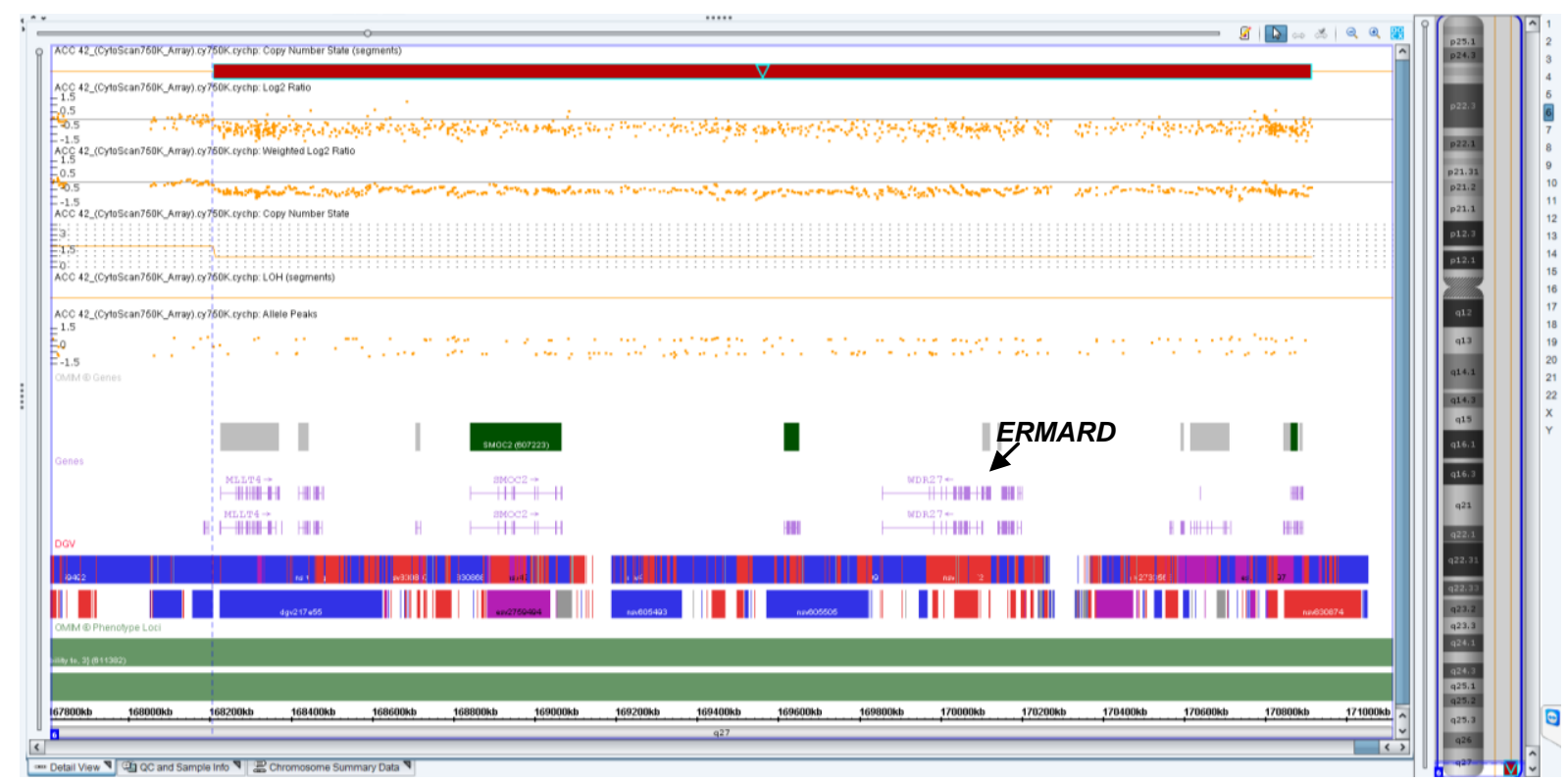

Figura 16. Exame de CMA na paciente ACC42, visualizado pelo ChAS versão 3.0 (Affymetrix, EUA), mostrando a deleção (barra vermelha na parte superior) afetando $2.7 \mathrm{Mb}$ da região citogenômica de $6 q 27(168,211,952-170,914,297)$, na qual está presente o gene ERMARD que possui provável papel no surgimento das alterações do desenvolvimento do CC. Exame realizado na plataforma CytoScan 750k Array (Affymetrix, EUA). 


\subsubsection{Paciente HUB5}

A paciente HUB5 é um menina com 12 anos de idade, possui cariótipo 46,XX, DCC visualizada por TC de encéfalo, e ADNPM (dificuldade para andar principalmente), dismorfias faciais (rosto alongado, epicanto bilateral, perfil facial achatado, nariz hipoplásico) e de membros (quirodactilia nas mãos, pés para dentro, ponta dos dedos afilados) com suspeita clínica para a Síndrome de Kabuki (MIM \#147920).

A CMA visualizou uma microdeleção de novo em 3q13.2-q13.31 (112,144,025$115,504,240$ ) de $3.3 \mathrm{Mb}$, afetando 29 genes (Figura 17). Esta região é, normalmente, associada à Síndrome da deleção 3q13.31 (MIM \#615433), na qual o gene GAP43 (OMIM: 162060) exerce um papel direto na regulação axonal modulando a formação de novas conexões (226). Além disso, os indivíduos afetados por esta síndrome normalmente apresentam alterações no CC que sustentam a suspeita de seu envolvimento no quadro clínico da paciente HUB5.

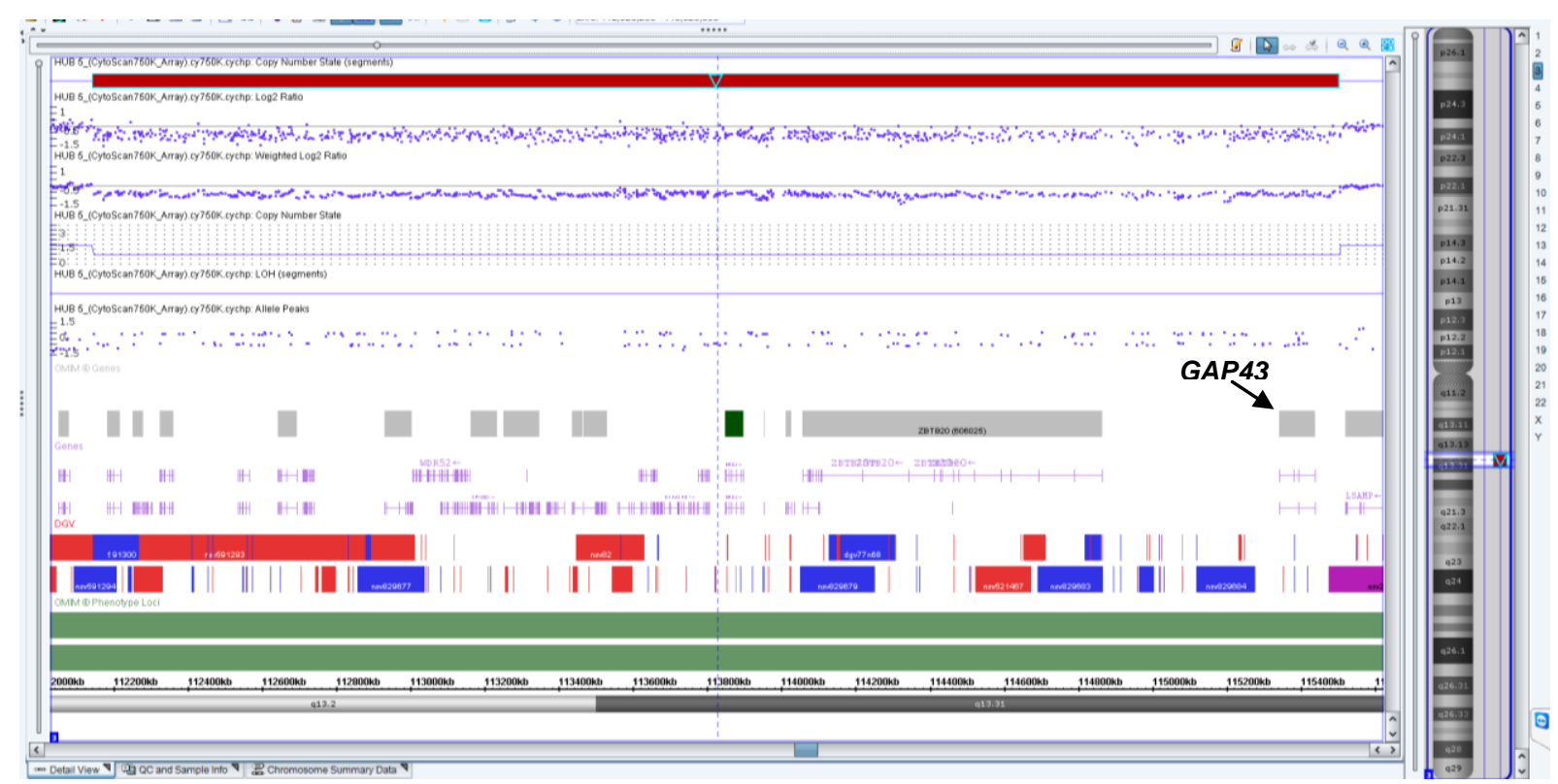

Figura 17. Exame de CMA na paciente HUB5, visualizado pelo ChAS versão 3.0 (Affymetrix, EUA), mostrando a deleção (barra vermelha na parte superior) encontrada com 3,3 $\mathrm{Mb}$ de tamanho na região citogenômica de 3q13.2-q13.31 (112,144,025-115,504,240), na qual o gene GAP43 é o candidato mais indicado para as alterações do CC encontradas na paciente. Exame realizado na plataforma CytoScan 750k Array (Affymetrix, EUA). 


\subsection{CNVS POTENCIALMENTE PATOGÊNICAS:}

\subsubsection{Paciente ACC6}

A paciente ACC6, 8 anos e 8 meses de idade, possui ACC parcial, cariótipo 46,XX, e diversas dismorfias tais como RM com redução da substância branca parieto-ociptal, dilatação ventricular, atraso motor e cognitivo, crises convulsivas até os 5 anos tratadas com medicamentos, dismorfias faciais (hipertelorismo, estrabismo divergente, fendas palpebrais oblíquas para baixo, epicanto bilateral, hipoplasia da face média, sobrancelhas ralas, assimetria facial discreta, baixa implantação bilateral de orelhas, dentes com má oclusão), implantação baixa de cabelos na região nucal, pregas palmares apagadas e discreta clinodactilia de $5^{\circ}$ dedo bilateral, pé plano, pectus excavatum, hipotireoidismo aos 3 anos, RM de encéfalo sugestivo de cisto da bolsa de Rathke hipofisário e macrossomia.

A análise por CMA indicou microduplicação de $426 \mathrm{~Kb}$ envolvendo a região genômica de 1p36.33p36.32 (2,116,349-2,542,740) afetando 15 genes (Figura 18), dos quais 8 possuem associações com morbidades descritas no OMIM: PRKCZ (176982), C1orf86 (615183), SKI (164780), PEX10 (602859), PLCH2 (612836), PANK4 (606162), HES5 (607348), TNFRSF14 (602746). Destes genes o SKI é um dos que mais influenciam diretamente nos processos de formação do CC visto que é responsável pela manutenção de grupos de células indiferenciadas e especificação dos neurônios calosais (227). Mas nos casos descritos na literatura enfocam na haploinsuficiência do gene $S K I$, que nas deleções de 1 p36 possuem impacto direto na $A C C$, como foi observado recentemente por meio da interação gênica no processo de especificação da projeção de neurônios calosais (227). Classicamente essa região possui descrições relacionadas com alterações na estrutura do CC envolvendo a Síndrome da deleção de 1 p36 (OMIM: 607872). Como o caso desta paciente envolve uma duplicação, a investigação de genes sensíveis à dose nesta região poderia auxiliar a entender o papel patogênico desta CNV. A maioria dos casos descritos para esta região envolvendo ACC tem etiologia das alterações baseada na haploinsuficiência gênica e não no ganho de função ou de mecanismos envolvendo dominância negativa. Existem exemplos na literatura de casos de genes dominantes cuja deleção promove o surgimento de um fenótipo patogênico (228, 
229) e casos envolvendo a complexa formação do CC ainda não foram estabelecidos.

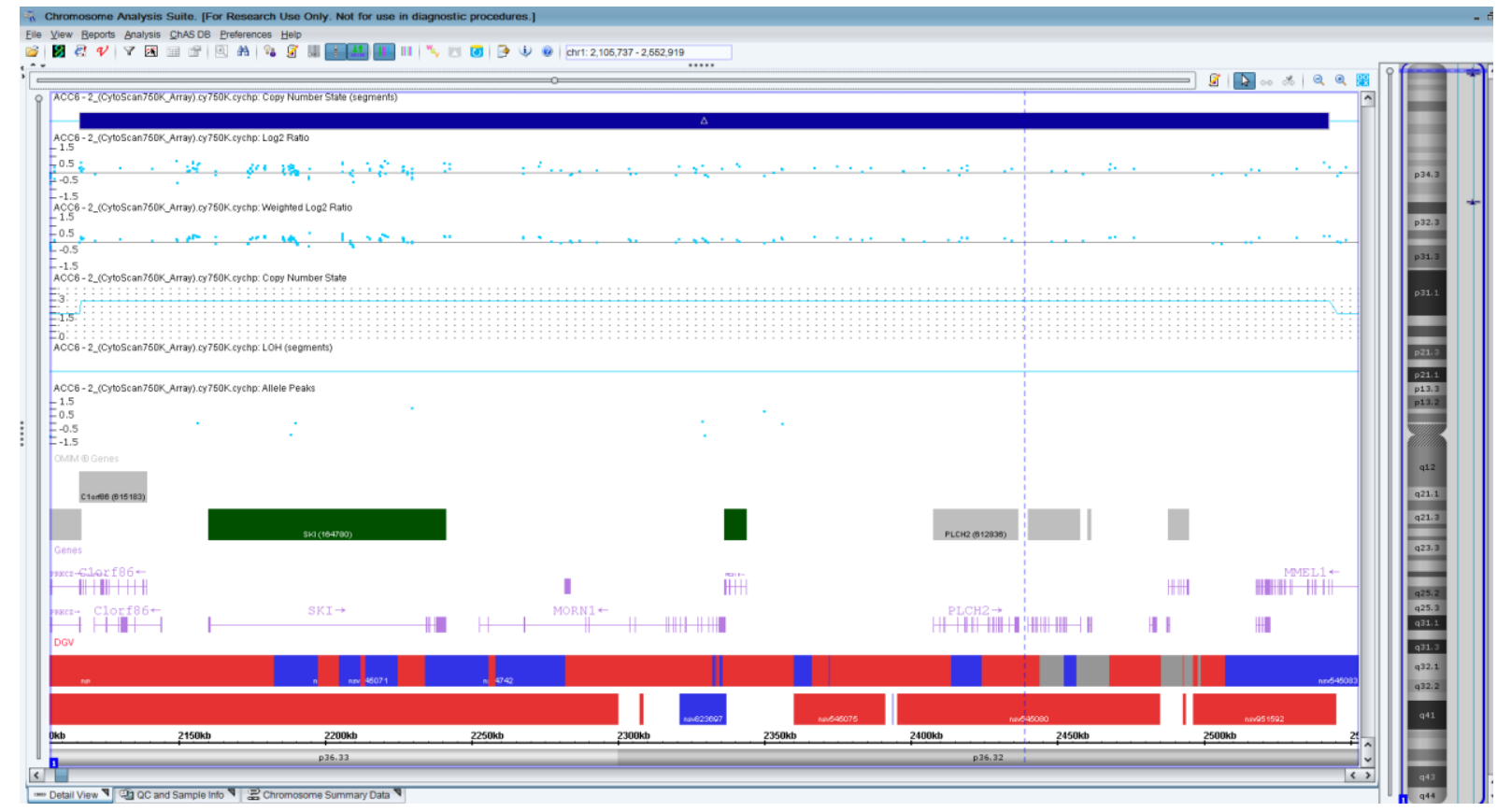

Figura 18. Exame de CMA, visualizado pelo software ChAS versão 3.0 (Affymetrix, EUA), da microduplicação (barra azul na parte superior) encontrada na paciente ACC6, com tamanho de 426 $\mathrm{Kb}$ afetando a região citogenômica de 1p36.33p36.32 (2,116,349-2,542,740). 


\subsubsection{Paciente ACC12}

O caso da paciente ACC12 de 2 anos e 8 meses envolve ACC parcial, cariótipo $46, \mathrm{XX}$, e diversas dismorfias associadas tais como fronte ampla, cabelos implantação alta, implantação profunda dos olhos, fenda palpebral para baixo, sobrancelhas arqueadas, raiz nasal larga e baixa, dorso reto, ponta bulbosa, narinas antervertidas, malformações em dedos da mão direita, agenesia da falange média e distal da mão esquerda, manchas hipercrômicas lineares em membro superior esquerdo, malformação epidérmica lombar, ânus anteriorizado. Apresentou quadro de mielomeningocele rôta, sepse neonatal e brida amniótica. A suspeita clínica era de síndrome do complexo da desorganização embrionária.

A análise por CMA revelou uma duplicação de novo 11p15.5 (372,355-538,463) de $166 \mathrm{~kb}$ afetando 8 genes na região (Figura 19), dos quais 5 possuem descrição associada à alterações fenotípicas no OMIM: PKP3 (605561), SIGIRR (605478), PTDSS2 (612793), RNH1 (173320), HRAS (190020). Sabe-se que esta é uma região genômica que está associada com diversas síndromes que possuem correlação com ACC, porém a CNVs descritas não se sobrepõem na mesma área de 11p15.5. Portanto, visto que ocorre proximidade com uma região tão importante para alterações do neurodesenvolvimento, pode ser que os genes encontrados ali também ajudem a regular o funcionamento de outros patogênicos próximos. 


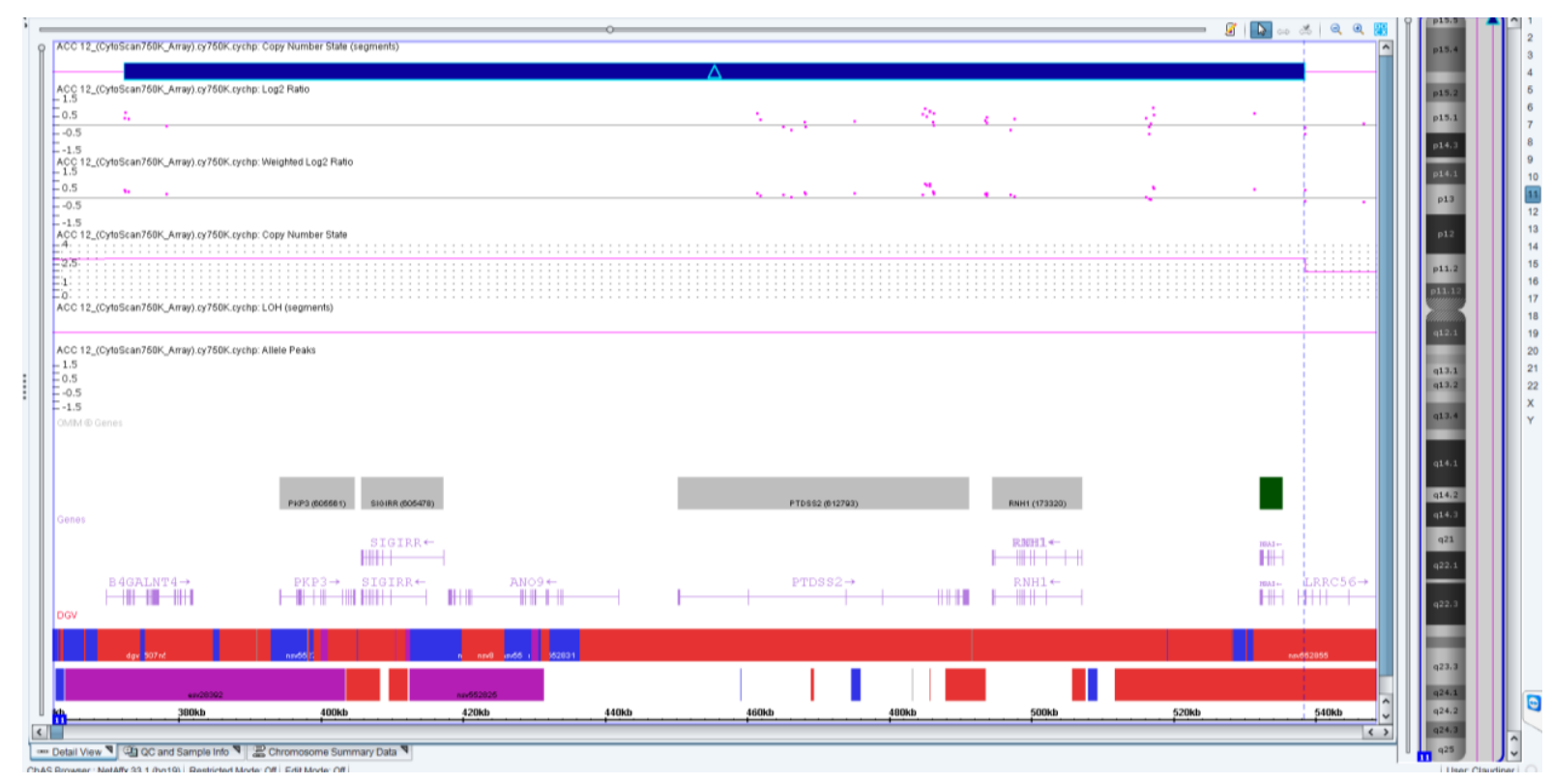

Figura 19. Representação gráfica, visualizada pelo software ChAS versão 3.0 (Affymetrix, EUA), da microduplicação (barra azul na parte superior) encontrada pelo exame de CMA na paciente ACC12, afetando 166 Kb da região citogenômica de 11 p15.5 (372,355-538,463). 


\subsubsection{Paciente ACC38}

O caso da paciente ACC38 envolve uma recém-nascida de um mês de vida, com ACC completa visualizada por USTF, com cariótipo 46, XX e um quadro sindrômico que incluía microcefalia, hipotonia sem sustento cefálico, múltiplas anomalias da face (fendas palpebrais oblíquas para cima, cílios longos, baixa implantação das orelhas, filtro nasolabial curto, implantação capilar baixa, hipertricose frontal), anomalias nos membros (clinodactilia de $5^{\circ}$ dedos nas mãos e pés, assimetria de membros), distúrbios de deglutição e queratoderma generalizada.

O exame de CMA revelou a presença de uma deleção de $1 \mathrm{Mb}$ em 22q11.21 $(20,716,876$ - 21,800,471), onde acaba afetando um grupo de 24 genes, dos quais se destaca o gene SNAP29, por sua provável correlação com o fenótipo da paciente sugerindo ser um caso de Síndrome de CEDNIK (MIM \#609528) (Figura 20). Porém, a CMA dos genitores correlacionou a mesma CNV presente no pai, sugerindo assim um mecanismo a ser esclarecido de herança autossômica recessiva para a doença.

Síndromes neurocutâneas representam um grupo vasto e heterogêneo de desordens caracterizadas por manifestações neurológicas e dermatológicas. Por meio do mapeamento da homozigose em duas grandes famílias, Sprecher e colaboradores (230) localizaram o gene da doença em 22q11.2 e identificaram, em todos os pacientes, deleção em SNAP29, o qual codifica um receptor protéico envolvido em fusão de vesículas. A expressão de SNAP29 foi diminuindo na pele dos pacientes, resultando em maturação anormal de grânulos lamelares e, consequentemente, na localização errada dos lipídios epidermais e proteases. Assim como a paciente ACC38, os pacientes do estudo de Sprecher compartilham diversas dismorfias faciais, microcefalia, xeratoderma, e diferentes níveis de anomalias no CC com displasia cortical, paquigira e polimicrogiria, combinado com grave ADNMP. Segundo Sprecher e colaboradores (230), a diferenciação epidermal é dependente da localização espacial correta de lipídios e enzimas proteolíticas que vão contribuir para formarem uma barreira na pele e mediar a descamação. No caso da Síndrome de CEDNIK, a distribuição e localização incorreta destes elementos provocam os problemas epiteliais verificados. Além disso, o gene SNAP29 participa de processos durante o desenvolvimento do cérebro, crescimento axonal, 
sinaptogênese e neurotransmissão, fatores que estão diretamente relacionados com ACC (231).

Outros estudos estão focados em entender a região crítica e os genes responsáveis pelos fenótipos compartilhados entre as diversas síndromes no que ficou conhecido como Síndrome da Deleção 22q11.2. Estudos para tentar entender a contribuição das deleções nesta região para a arquitetura neuronal descobriram que genes que estão localizados fora da região de $1,5 \mathrm{Mb}$, mas dentro da região de $3 \mathrm{Mb}$ de 22q11.2 deletada podem contribuir para as manifestações neuronais. Dentre estes genes, encontra-se SNAP29 que modula a função da maquinaria que media a fusão de membranas, passo essencial para reciclagem de vesículas sinápticas. Baixos níveis de SNAP29 em neurônios primários afetam a transmissão sináptica (232), enquanto mutações truncadas homozigotas do gene provocam displasia cortical (233) e anormalidades no CC. A deficiência de outro gene (CRKL) na região de $3 \mathrm{Mb}$ pode afetar os processos de sinalização celular envolvendo proteínas da matriz extracelular que são fundamentais para o posicionamento e migração neuronal durante o desenvolvimento cerebral (230).

No entanto, ainda permanecem desconhecidos quando um destes genes está haploinsuficiente em 22q11.2. Desta forma, a paciente ACC38 pode ter herdado uma cópia mutada de SNAP29 do lado materno ou ter ocorrido uma mutação de novo de tal forma que sem a cópia do alelo, por conta da deleção herdada do pai, a paciente torna-se um excelente modelo para o entendimento do mecanismo de herança dessa condição. 


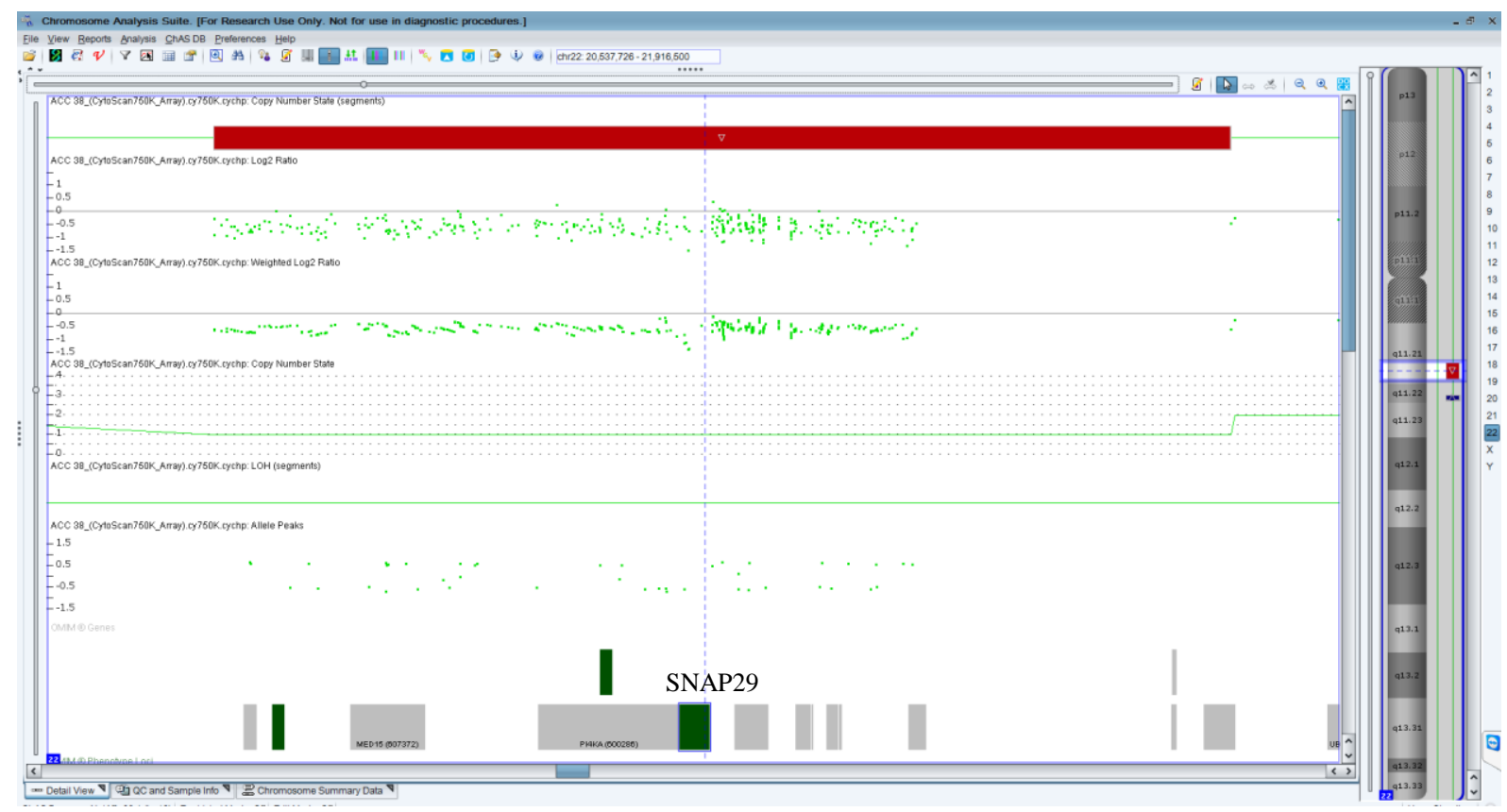

Figura 20. Representação gráfica, visualizada pelo software ChAS versão 3.0 (Affymetrix, EUA), da deleção (barra vermelha) encontrada pelo exame de CMA na paciente ACC38, afetando $1 \mathrm{Mb}$ da região citogenômica de $4 p$ del 22q11.21 (20,716,876-21,800,471), na qual o gene SNAP29, relacionado com a Síndrome de CEDNIK, sugere envolvimento nas alterações do desenvolvimento do CC. 


\subsection{CNVS VOUS}

Um desafio imposto pelos estudos de CMA atualmente é a identificação de CNVs para as quais existe pouca ou nenhuma informação clínica. Esses achados, classificados de VOUS, podem representar dificuldade de interpretação e compreensão tanto por parte do profissional que realiza o exame quanto pela família do indivíduo afetado. Um detalhe que chama atenção, é que o aumento no número de sondas do array não levou necessariamente a um aumento equivalente no rendimento diagnóstico. Por exemplo, comparando um chip de 44k com um de $180 \mathrm{k}$ o aumento real no rendimento diagnóstico é de apenas 3\% (234).

Importante observar que uma das principais dificuldades de se interpretar as VOUS são algumas características que podem sugerir uma relação causal ou não com o quadro clínico do paciente. A VOUS possivelmente patogênica ocorreria quando houvesse descrição de um único caso com a mesma CNV, e este caso seria bem caracterizado, tanto do ponto de vista citogenômico como clínico, e teria relação com os achados do paciente. Também seria considerada possivelmente patogênica uma CNV que possuísse um gene com função relevante e específica associada ao fenótipo do paciente. Por outro lado, a VOUS possivelmente benigna ocorreria quando se registrasse uma CNV sem genes ou descrita tanto em pacientes como em controles nos bancos de dados, mas que não chegasse a ter número suficiente para ser um polimorfismo. E, finalmente, a VOUS sem especificação seria quando a CNV contivesse genes, mas que não se sabe se são sensíveis à dosagem ou se há descrição de forma contraditória na literatura, não havendo ainda uma correlação clínica significativa com alguma patologia. Caso não seja possível identificar a origem paterna da CNV, ela também pode ser classificada neste grupo (234).

Nos pacientes ACC7, ACC28, ACC33, e HUB 3 encontramos CNVs (Tabela 9) para as quais não puderam ser elencadas sugestões de genes ou fenômenos genéticos que explicassem o fenótipo do paciente. Desta forma classificamos estas alterações como de significado clínico desconhecido (VOUS) em virtude da falta de informações na literatura que pudessem ajudar em alguma hipótese e falta de outros pacientes com alterações fenotípicas similares nos bancos de dados.

O paciente ACC7 possui uma microdeleção, de origem materna, com $402 \mathrm{~Kb}$ na região 16q23.3 $(82,521,529-82,923,743)$ (Figura 21). Esta alteração afeta a parte 
inicial do gene $C D H 13$, afetando os três primeiros introns. Este gene codifica uma proteína receptora de membrana envolvida em processos de sinalização celular em vias metabólicas cuja disfunção está associada à tumores de mama e de pulmão, portanto, sem correlação com distúrbios do $\mathrm{CC}$ até o momento. O paciente possui ACC completa visualizada por meio de duas USTF diferentes, quadro clínico registra nascimento prematuro com 36 semanas de gestação, hemorragia pulmonar, acidose metabólica, anomalias faciais (fendas palpebrais retas, leve hipertricose frontal, hemangioma no ocipto e na narina, orelhas com sobredrobramento de hélice e rodadas à esquerda), pescoço curto, hiperextensibilidade articular nas mãos, pés planos, alterações gastrointestinais (estômago à direita e duodeno à esquerda, intestino grosso à direita, regurgitações frequentes). Existem alterações clínicas na mãe tais como diabetes mellitus tipo I, insuficiência renal crônica e deficiência visual, além do exame da CMA que detectou a microdeleção transmitida ao filho. E no pai que, por sua vez, possui deficiência visual grave, microftalmia, orelhas com baixa implantação, aracnodactilia e hiperextensibilidade articular nas mãos com CMA sem alterações. Em ambos os parentais não foi possível investigar a presença ou não de alterações no CC.

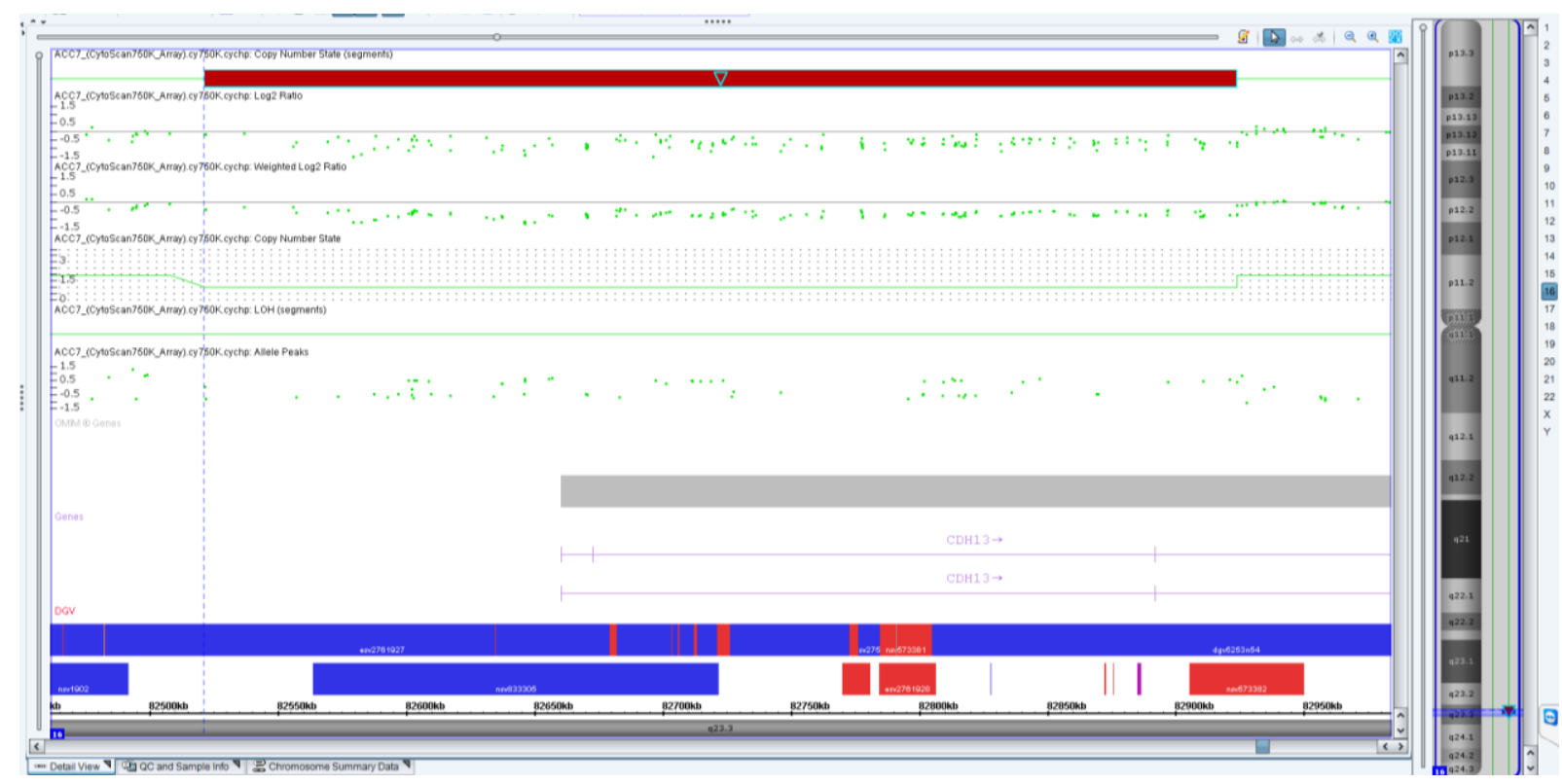

Figura 21. Representação gráfica, visualizada pelo software ChAS versão 3.0 (Affymetrix, EUA), da duplicação (barra azul), de origem materna, encontrada pelo exame de CMA no paciente ACC7, afetando $402 \mathrm{~Kb}$ da região citogenômica de $16 q 23.3$ (82,521,529-82,923,743), onde se encontra o gene $\mathrm{CDH} 13$. 
O paciente ACC28 apresenta uma microduplicação, de origem paterna, na região de 6 q15 $(90,172,098-90,386,150)$ com tamanho de $214 \mathrm{~Kb}$ e afetando três genes (Figura 22). Destes o mais comprometido pela duplicação seria o gene $A N K R D 6$, cuja função sugerida por estudos em modelos animais aponta para o envolvimento na ativação dos movimentos de gastrulação. O paciente apresenta ACC completa, visualizada por TC de crânio, além de ter ficado internado em UTI neonatal e necessitado de reanimação pós-parto. Apresenta diversas alterações tais como hidrocefalia, hemimegaencefalia esquerda, displasia cortical, não possui sustento encefálico, apresenta ADNPM, convulsões, dismorfica faciais (fendas palpebrais longas obliquas para cima, nistagmo com desvio ocular à direita, úlcera de córnea, baioxa implantação e rotação posterior das orelhas, apêndice préauricular à direita, assimetria facial com lado direito maior que o esquerdo, micrognatia, sobrancelhas levemente arqueadas, raiz nasal baixa e ponta bulbosa do nariz), anomalias nos membros (polidactilia, pés com implantação anormal dos dedos, sulcos profundos), hepatomegalia, e episódios de hipoglicemia quando estava sem hidratação venosa. Não foi possível analisar os parentais após o exame da CMA que constatou esta duplicação que o pai transmitiu ao filho.

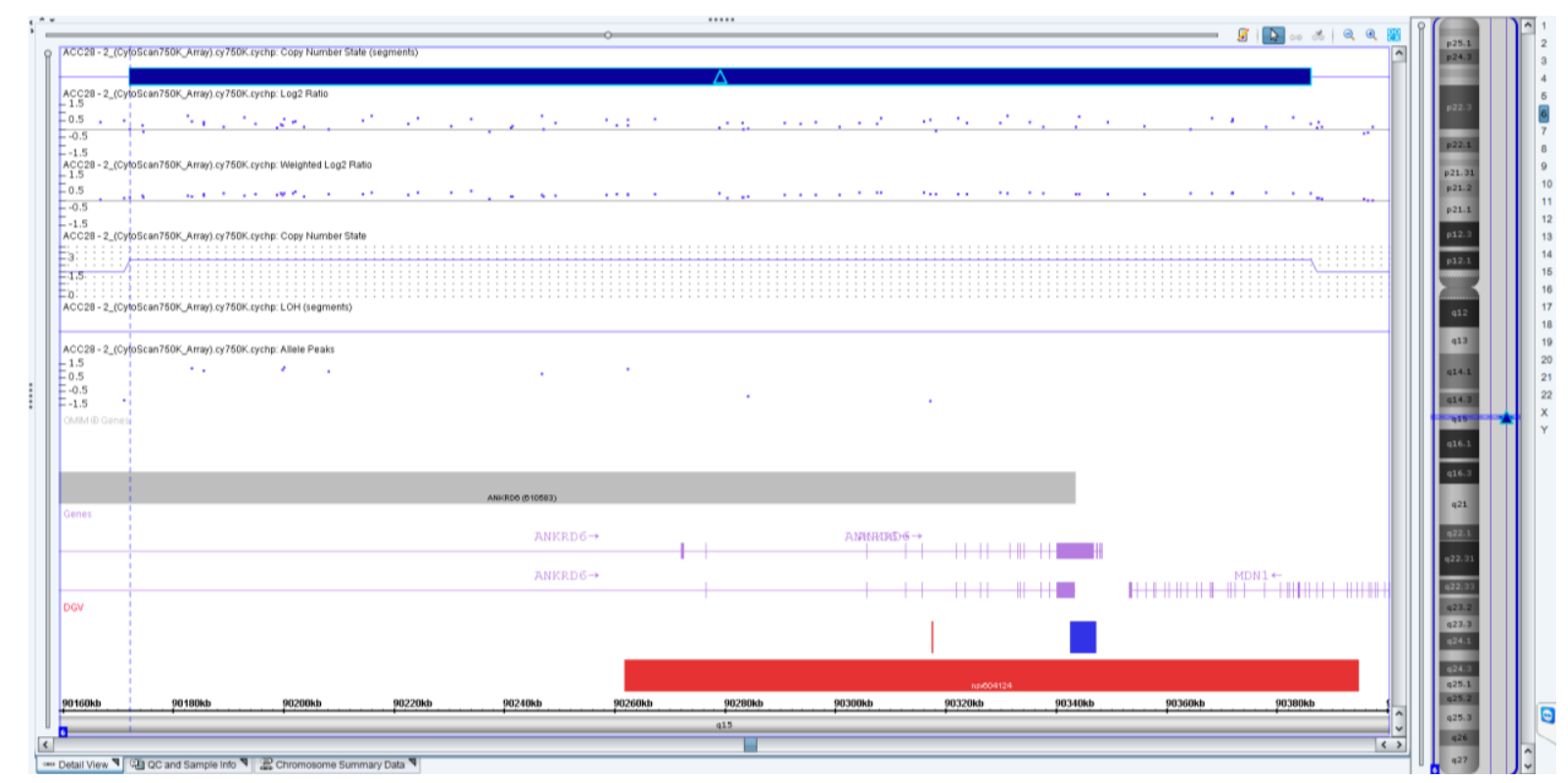

Figura 22. Representação gráfica, visualizada pelo software ChAS versão 3.0 (Affymetrix, EUA), da duplicação (barra azul), de origem paterna, encontrada pelo exame de CMA no paciente ACC28, afetando $214 \mathrm{~Kb}$ da região citogenômica de $6 q 15$ (90,172,098-90,386,150), onde se encontra o gene ANKRD6. 
A paciente ACC33, possui ACC completa visualizada por TC de crânio, e o exame de CMA detectou uma microdeleção em Xq21.1 (76,915,402-76,946,445) com tamanho de $31 \mathrm{~Kb}$ afetando apenas parte do gene ATRX (Figura 23). Este gene codifica uma helicase que além de regular a expressão gênica interagindo com a heterocromatina, sua mutação está associada com algumas formas de deficiência intelectual e com a Síndrome de Rett (MIM \#312750). Estudos com culturas de células e com modelos animais sugerem que este papel esteja correlacionado com sua função em processos nucleares e interações dosagem dependente com outras proteínas. A paciente possui um quadro clínico complicado que envolve encefalocele occipital, assimetria craniana, cerebral e ventricular, anomalias faciais (hipertelorismo, fendas palpebrais oblíquas para cima, coloboma de íris, implantação baixa das orelhas que estão rodadas para trás, hipoplasia de hélice, fenda lábiopalatina, raiz nasal baixa e larga) e pescoço curto.

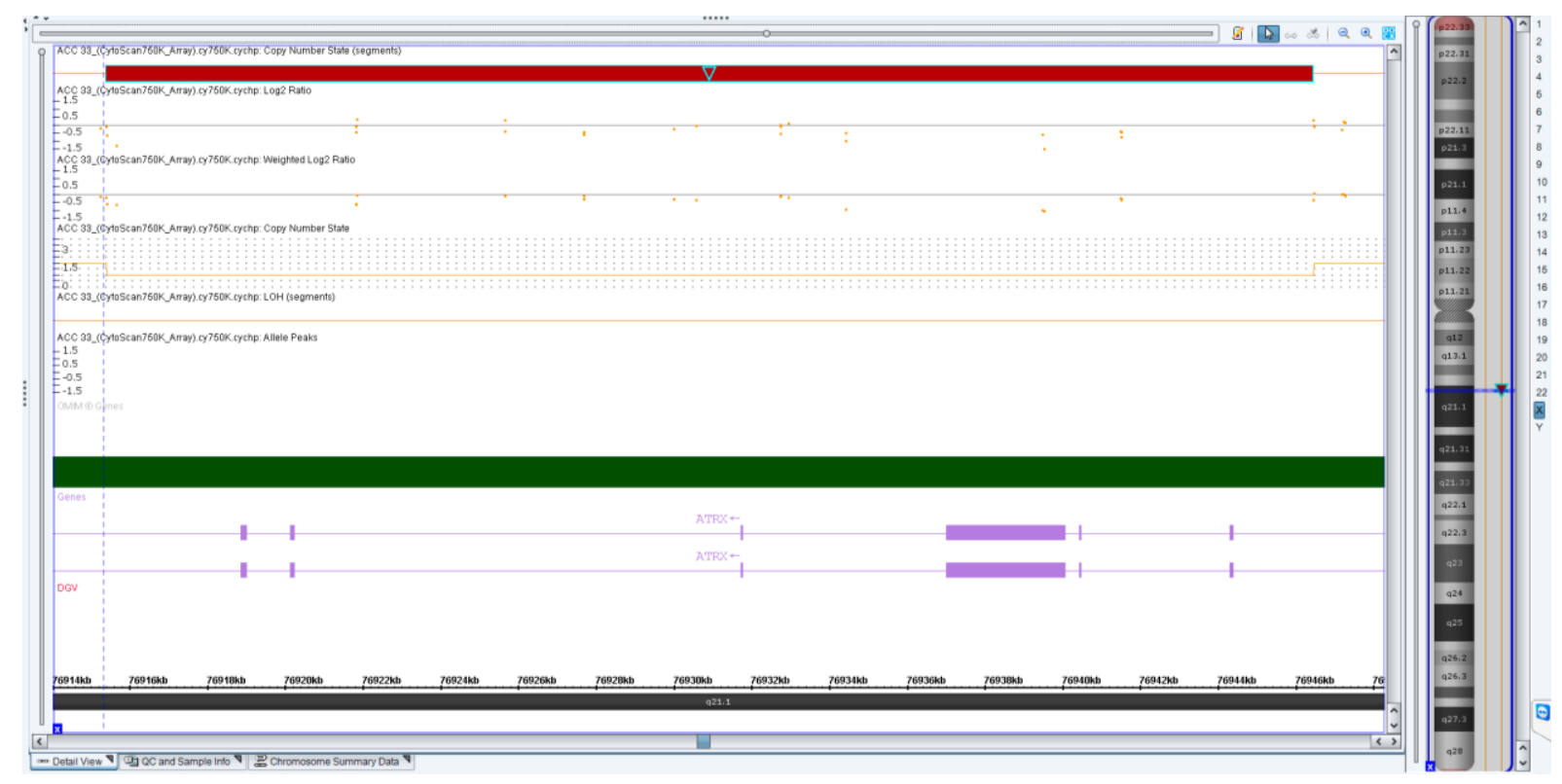

Figura 23. Representação gráfica, visualizada pelo software ChAS versão 3.0 (Affymetrix, EUA), da deleção (barra vermelha), encontrada pelo exame de CMA na paciente ACC33, afetando $31 \mathrm{~Kb}$ da região citogenômica de del Xq21.1 (76,915,402-76,946,445), onde se encontra o gene ATRX.

E, finalmente, o paciente HUB3 apresentou ao exame da CMA uma microduplicação de $691 \mathrm{~Kb}$ na região de 16p12.2 (21,740,199-22,431,031) afetando dez genes no total (Figura 24). Destes, o gene EEF2K possui um papel melhor estabelecido no tecido neural com sua proteína, evolutivamente conservada, 
atuando como uma enzima quinase reguladora do movimento dos ribossomos ao longo do mRNA durante a tradução em células eucarióticas. O paciente possui uma ACC completa, visualizada por meio de RMN de crânio e encéfalo, com quadro clínico que envolve deficiência intelectual, grave ADNPM, hiperplasia do epitélio pigmentado da íris, estrabismo convergente e obesidade mórbida que se iniciou no primeiro mês de vida.

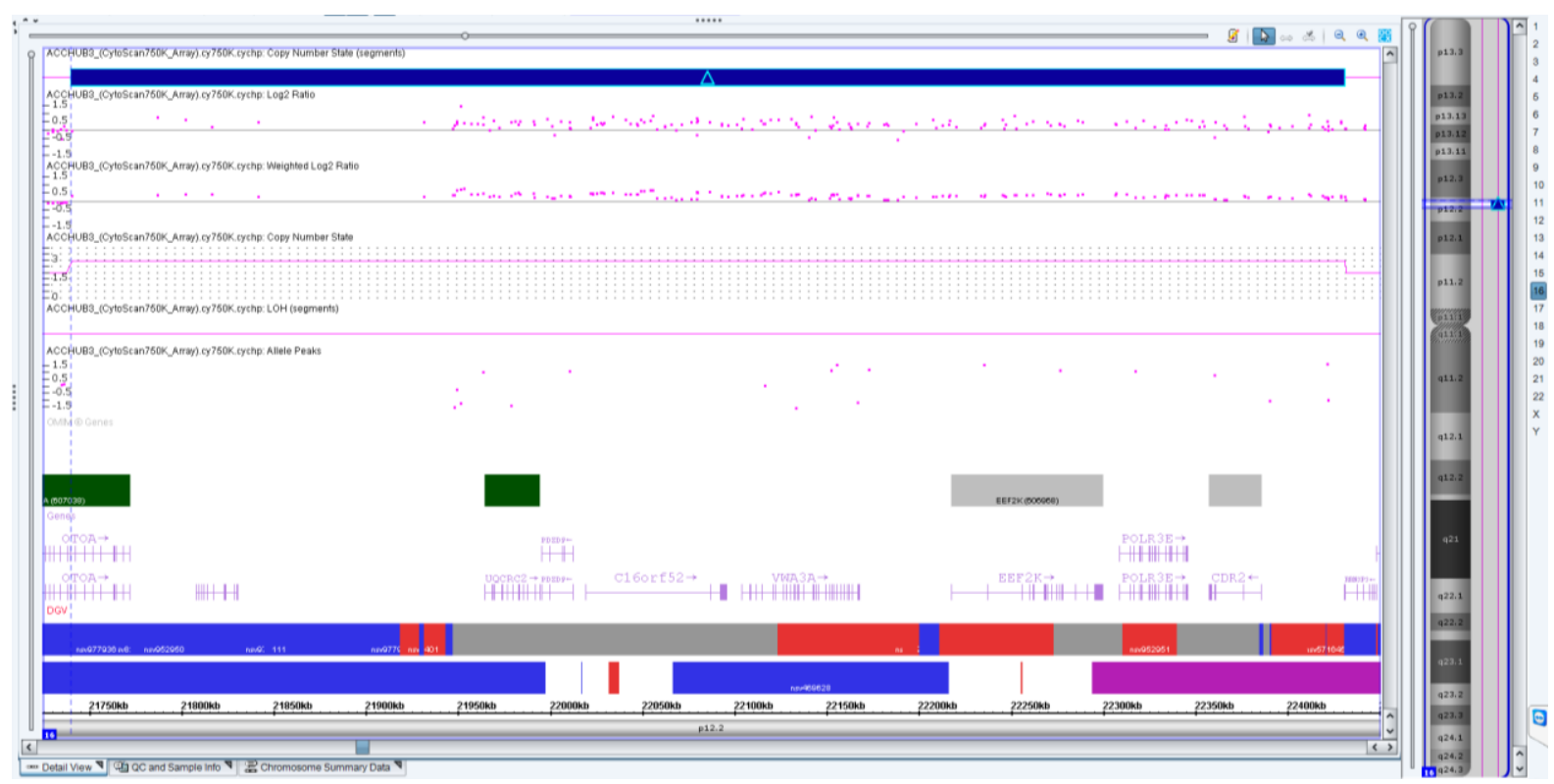

Figura 24. Representação gráfica, visualizada pelo software ChAS versão 3.0 (Affymetrix, EUA), da duplicação (barra azul) encontrada pelo exame de CMA no paciente HUB3, afetando 691 Kb da região citogenômica de $6 q 15(90,172,098-90,386,150)$, onde se encontra o gene EEF2K. 


\section{CONCLUSÕES}

1. A taxa diagnóstica encontrada neste estudo (24\%) demonstrou que a CMA é um método diagnóstico bastante eficiente para estudar a causa genética de distúrbios do desenvolvimento envolvendo o CC.

2. Com relação aos sinais e sintomas que obtiveram maior taxa de diagnóstico destacam-se efetivamente a ACC parcial (41\%), DI (30\%), dificuldade no aprendizado e anomalias oftalmológicas com $28 \%$ cada e dificuldades na fala com $27 \%$.

3. A CMA revelou que $32 \%$ dos indivíduos apresentaram pelo menos uma CNV não descrita no DGV, que foi analisada quanto aos possíveis mecanismos de herança e potencial patogênico.

4. Por meio da CMA foi possível comprovar que em 50\% dos indivíduos as alterações numéricas encontradas eram de novo.

5. Do total de indivíduos com CNVs não descritas no DGV, 64\% apresentaram somente microduplicações e/ou microdeleções que não poderiam ser detectadas pela citogenética convencional.

6. De um total de 19 CNVs avaliadas, $76 \%$ são patogênicas (10) ou potencialmente patogênicas (3), pois apresentaram uma única alteração que foi suficiente para determinar ou associar à patologia, incluindo as anomalias do CC.

7. $24 \%$ das CNVs raras analisadas foram interpretadas de significado clínico desconhecido ou VOUS.

8. Dentre as CNVs patogênicas e potencialmente patogênicas estamos propondo um grupo de 13 genes candidatos diversos cujas funções nem sempre estiveram ligadas ao desenvolvimento alterado do CC: WT1 (607102), PAX6 (194072), NCAM2 (602040), WHSC1 (602952), CRBN (609262), SETD5 
(615743), SOX2 (184429), ZIC2 (603073), NALCN (611549), HCCS (309801), ERMARD (615532), GAP43 (162060), SNAP29 (604202). Além disso, estamos propondo mais estudos para se estabelecer a região crítica de 5 regiões citogenômicas cujas CNVs podem ter associação com o desenvolvimento do CC: microduplicação em 1p36.33, duplicação em 5p15.33q11.1, microdeleção em 8q12.1, e microduplicação em 11 p15.5 


\section{REFERÊNCIAS BIBLIOGRÁFICAS}

1 - American Psychiatric Association; Diagnostic and statistical manual of mental disorders 5th ed. tradução: Maria Inês Corrêa Nascimento et al [Manual diagnóstico e estatístico de transtornos mentais: DSM-V ]; revisão técnica: Aristides Volpato Cordioli et al 5 ed: p.33. Porto Alegre: Artmed, 2014.

2 - Buntinx WHE, Schalock RL. Models of Disability, Quality of Life, and Individualized Supports: Implications for Professional Practice in Intellectual Disability. J Policy and Pract in Intellect Disabil. 2010(7): 283-294.

3 - AAIDD - American Association on Intellectual and Developmental Disabilities. Definition of Intellectual Disability. Disponível em: <http://www.aamr.org>. Acesso em: março, 2015.

4 - Roselló M, et al. Phenotype profiling of patients with intelectual disability and copy number variations. Eur J Paediatr Neurol. 2014(18): 558-66.

5 - Chelly J, et al. Genetics and pathophysiology of mental retardation. Eur J Hum Genet. 2006(6):701-13.

6 - Vissers LE, de Vries BB, Veltman JA. Genomic microarrays in mental retardation: from copy number variation to gene, from research to diagnosis. $J$ Med Genet. 2010; 47(5):289-97.

7 - Leonard $\mathrm{H}$, Wen $\mathrm{X}$. The epidemiology of mental retardation: challenges and opportunities in the new millennium. Ment Retard Dev Disabil Res Rev 2002(8):117-34 .

8 - Kramer JM, van Bokhoven H. Genetic and epigenetic defects in mental retardation. Int J Biochem Cell Biol. 2009; 41(1):96-107.

9 - van Bokhoven H. Genetic and Epigenetic Networks in Intellectual Disabilities. Ann Rev Genet. 2011; 45:81-104.

10 - Centers for Disease Control and Prevention (CDC). Economic costs associated with mental retardation, cerebral palsy, hearing loss, and vision impairment United States, 2003. MMWR Morb Mortal Wkly Rep. 2004; 53(3):57-9.

11 - Fineberg NA, Haddad PM, Carpenter L, et al. The size, burden and cost of disorders of the brain in the UK. J Psychopharmacol. 2013; 27(9):761-770.

12 - Ropers, HH. Genetics of Early Onset Cognitive Impairment. Annu Rev Genomics Hum Genet. 2010;11:161-87.

13 - Corde. Relatório sobre a prevalência de deficiências, incapacidades e desvantagens. Niterói: Ministério da Justiça/CORDE/AFR, 2004.

14 - IBGE. Censo Demográfico 2010: Características gerais da população, religião e pessoas com deficiência. Resultados preliminares a amostra. IBGE, 2011. 
Disponível

em:

http://www.ibge.gov.br/home/estatistica/populacao/censo2010/resultados_prelimi nares_amostra/default_resultados_preliminares_amostra.shtm. Acesso em março de 2015.

15 - Shaffer LG. American College of Medical Genetics guideline on the cytogenetic evaluation of the individual with developmental delay or mental retardation. Genet Med. 2005; 7(9):650-4.

16 - Rauch A, Hoyer J, Guth S, Zweier C, Kraus C, et al. Diagnostic yield of various genetic approaches in patients with unexplained developmental delay or mental retardation. Am J Med Genet Part A. 2006; 140: 2063-2074.

17 - Xu J, Chen Z. Advances in Molecular Cytogenetics for the Evaluation of Mental Retardation. Am J Med Genet C Semin Med Genet. 2003;117C(1):15-24.

18 - Yeargin-Allsopp M, Murphy CC, Cordero JF, Decouflé P, Hollowell JG. Reported biomedical causes and associated medical conditions for mental retardation among 10-year-old children, metropolitan Atlanta, 1985 to 1987. Dev. Med Child. Neurol. 1997; 39: 142-9.

19 - Toscano CD, Guilarte TR. Lead neurotoxicity: from exposure to molecular effects. Brain Res Brain Res Rev. 2005; 49: 529-554.

20 - Armatas V. Mental retardation: definitions, etiology, epidemiology and diagnosis. $J$ Sport and Health Res. 2009; 1(2):112-122.

21 - Moeschler JB, Shevell M. Clinical Genetic Evaluation of the Child With Mental Retardation or Developmental Delays. Pediatrics. 2006;117: 2304-2316.

22 - Inlow JK, Restifo LL. Molecular and comparative genetics of mental retardation. Genetics. 2004;166(2):835-81.

23 - de Vries BBA, et al. Clinical studies on submicroscopic subtelomeric rearrangements: a checklist. J Med Genet. 2001; 38(3):145-150.

24 - de Vries BBA. Telomeres: a diagnosis at the end of the chromosomes. J Med Genet. 2003; 40(6):385-398.

25 - Cooper GM, Coe BP, Girirajan S, Rosenfeld JA, Vu TH, Baker C, et al. A copy number variation morbidity map of developmental delay. Nat Genet. 2011; 43(9):838-46.

26 - Kaminsky EB, Kaul V, Paschall J, Church DM, Bunke B, Kunig D, et al. An evidence-based approach to establish the functional and clinical significance of copy number variants in intellectual and developmental disabilities. Genet Med. 2011; 13: 777-784.

27 - Zahir F, Friedman JM. The impact of array genomic hybridization on mental retardation research: a review of current technologies and their clinical utility. Clin Genet. 2007;72(4):271-87. 
28 - Hochstenbach R, et al. Array analysis and karyotyping: workflow consequences based on a retrospective study of 36,325 patients with idiopathic developmental delay in the Netherlands. Eur J Med Genet. 2009; 52: 161-9.

29 - Miller DT, Adam MP, Aradhya S, Biesecker LG, Brothman AR, Carter NP, et al. Consensus Statement: Chromosomal Microarray is a First-Tier Clinical Diagnostic Test for Individuals with Developmental Disabilities or Congenital Anomalies. Am J Hum Genet. 2010; 14;86(5):749-64.

30 - Das D. Molecular aberration studies in cases of idiopathic mental retardation: An update. Indian J Hum Gen. 2013; 19: 123-4.

31 - Xiang B, Zhu H, Shen Y, Miller DT, Lu K, et al. Genome-wide oligonucleotide array comparative genomic hybridization for etiological diagnosis of mental retardation: a multicenter experience of 1499 clinical cases. J Mol Diagn. 2010;12:204-1.

32 - Sagoo GS, Butterworth AS, Sanderson S, Shaw-Smith C, Higgins JP, Burton H. Array CGH in patients with learning disability (mental retardation) and congenital anomalies: updated systematic review and meta-analysis of 19 studies and 13,926 subjects. Genet Med. 2009;11(3):139-46.

33 - Chayim CS. et al Agenesis and Dysgenesis of the Corpus Callosum: Clinical, Genetic and Neuroimaging Findings in a Series of 41 Patients. Am J Med Genet A. 2008; 146 (19): 2501-2511.

34 - Palmer EE, Mowat D. Agenesis of the corpus callosum: A clinical approachto diagnosis. Am J Med Genet Part C Semin Med Genet 2014. 166C:184-197.

35 - Aboitiz F, Montiel J. One hundred million years of interhemispheric communication: the history of the corpus callosum. Braz J Med Biol Res. 2003; 36(4):409-20 .

36 - Paul LK. Developmental malformation of the corpus callosum: a review of typical callosal development and examples of developmental disorders with callosal involvement. J Neurodev Disord 2011; 3:3-27.

37 - Hinkley LB, Marco EJ, Findlay AM, Honma S, Jeremy RJ, Strominger Z, Bukshpun P, Wakahiro M, Brown WS, Paul LK, Barkovich AJ, Mukherjee P, Nagarajan SS, Sherr EH. The role of corpus callosum development in functional connectivity and cognitive processing. PLoS One. 2012;7(8):e39804.

38 - Witelson SF. Hand and sex differences in the isthmus and genu of the human corpus callosum. A postmortem morphological study. Brain. 1989; 112:799-835.

39 - Wahl M, Strominger Z, Jeremy RJ, Barkovich AJ, Wakahiro M, Sherr EH, et al Variability of homotopic and heterotopic callosal connectivity in partial agenesis of the corpus callosum: a $3 \mathrm{~T}$ diffusion tensor imaging and Q-ball tractography study. AJNR Am J Neuroradiol 2009; 30:282-9. 
40 - Edwards TJ, Sherr EH, Barkovich AJ, Richards LJ. Clinical, genetic and imaging findings identify new causes for corpus callosum development syndromes. Brain 2014; 137(Pt 6):1579-613.

41 - Hofer S. \& Frahm, J. Topography of the human corpus callosum revisited comprehensive fiber tractography using diffusion tensor magnetic resonance imaging. Neuroimage. 2006; 32: 989-994.

42 - Frazier TW, Hardan AY. A meta-analysis of the corpus callosum in autism. Biol Psychiatry. 2009; 66:935-41.

43 - Davila-Gutierrez G. Agenesis and dysgenesis of the corpus callosum. Semin Pediatr Neurol. 2002; 9:292-301

44 - Penny SM. Agenesis of the corpus callosum: neonatal sonographic detection. Radiol Technol. 2006; 78(1): 14-8.

45 - Schell-Apacik CC, Wagner K, Bihler M, Ertl-Wagner B, Heinrich U, Klopocki E, et al. Agenesis and dysgenesis of the corpus callosum: clinical, genetic and neuroimaging findings in a series of 41 patients. Am J Med Genet $A$ 2008; 146A:2501-11.

46 - Tang PH, Bartha Al, Norton ME, Barkovich AJ, Sherr EH, Glenn OA. Agenesis of the corpus callosum: an MR imaging analysis of associated abnormalities in the fetus. AJNR Am J Neuroradiol. 2009; 30:257-63.

47 - Hanna RM, Marsh SE, Swistun D, Al-Gazali L, Zaki MS, Abdel-Salam GM, et al. Distinguishing 3 classes of corpus callosal abnormalities in consanguineous families. Neurology. 2011; 76 (4): 373-82.

48 - Fame RM, MacDonald JL, Macklis JD. Development, specification, and diversity of callosal projection neurons. Trends Neurosci. 2011; 34:41-50.

49 - Luders E, Thompson PM, Toga AW. The development of the corpus callosum in the healthy human brain. J Neurosci. 2010; 30:10985-90.

50 - Garel C, Cont I, Alberti C, Josserand E, Moutard ML, Ducou le Pointe H. Biometry of the corpus callosum in children: MR imaging reference data. AJNR Am J Neuroradiol. 2011; 32:1436-43.

51 - Santo S, D'Antonio F, Homfray T, Rich P, Pilu G, Bhide A, et al Counseling in fetal medicine: agenesis of the corpus callosum. Ultrasound Obstet Gynecol 2012; 40:513-21.

52 - Ghi T, Carletti A, Contro E, Cera E, Falco P, Tagliavini G, et al Prenatal diagnosis and outcome of partial agenesis and hypoplasia of the corpus callosum. Ultrasound Obstet Gynecol. 2010; 35:35-41.

53 - Paladini D, Pastore G, Cavallaro A, Massaro M, Nappi C. Corpus callosum agenesis in the fetus. Sonographic signs change with advancing gestational age. Ultrasound Obstet Gynecol. 2013; 42:687-90. 
54 - Hetts SW, Sherr EH, Chao S, Gobuty S, Barkovich AJ. Anomalies of the corpus callosum: an MR analysis of the phenotypic spectrum of associated malformations. AJR Am J Roentgenol. 2006; 187:1343-8.

55 - Volpe P, Campobasso G, De Robertis V, Rembouskos G. Disorders of prosencephalic development. Prenat Diagn. 2009; 29(4):340-54.

56 - Glass HC, Shaw GM, Ma C, Sherr EH. Agenesis of the corpus callosum in California 1983-2003: a population-based study. Am J Med Genet A 2008; 146A:2495-500.

57 - Lau YC, Hinkley LB, Bukshpun P, Strominger ZA, Wakahiro ML, Baron-Cohen S, et al Autism traits in individuals with agenesis of the corpus callosum. $J$ Autism Dev Disord. 2013; 43:1106-18.

58 - Siffredi V, Anderon V, Leventer RJ, Spencer-Smith MM. Neuropsychological profile of agenesis of the corpus callosum: a systematic review. Dev Neuropsychol. 2013; 38:36-57.

59 - Sotiriadis A, Makrydimas G. Neurodevelopment after prenatal diagnosis of isolated agenesis of the corpus callosum: an integrative review. Am J Obstet Gynecol. 2012; $206: 337$ e1-5.

60 - Paul LK, Brown WS, Adolphs R, Tyszka JM, Richards LJ, Mukherjee P, et al. Agenesis of the corpus callosum: genetic, developmental and functional aspects of connectivity. Nat Rev Neurosci. 2007; 8:287-99.

61 - O'Driscoll M; Black G, Clayton-Smith J, Sherr EH, Dobins WB. Identification of genomic loci contributing to agenesis corpus callosum. Am J Med Genet. 2010 152A: 2145-2159.

62 - Bedeschi MF, et al. Agenesis of the corpus callosum: clinical and genetic study in 63 young patients. Pediatr Neurol. 2006; 34:186-93.

63 - Barkovich AJ, Lyon G, Evrard P. Formation, maturation, and disorders of white matter. AJNR Am J Neuroradiol.1992; 13:447-61.

64 - Ren T, Anderson A, Shen WB, Huang H, Plachez C, Zhang J, et al. Imaging, anatomical, and molecular analysis of callosal formation in the developing human fetal brain. Anat Rec A Discov Mol Cell Evol Biol. 2006; 288:191-204.

65 - Huang H, Zhang J, Wakana S, Zhang W, Ren T, Richards LJ, et al. White and gray matter development in human fetal, newborn and pediatric brains. Neuroimage. 2006; 33:27-38.

66 - Lent R, Uziel D, Baudrimont M, Fallet C. Cellular and molecular tunnels surrounding the forebrain commissures of human fetuses. J Comp Neurol. 2005; 483:375-82.

67 - Molyneaux BJ, Arlotta P, Fame RM, MacDonald JL, MacQuarrie KL, Macklis JD. Novel subtype-specific genes identify distinct subpopulations of callosal projection neurons. J Neurosci. 2009; 29:12343-54. 
68 - Kallioniemi A, et al. Comparative genomic hybridization for molecular cytogenetic analysis of solid tumors. Science. 1992; 258:818-821.

69 - Solinas-Toldo S, et al. Matrix-based comparative genomic hybridization: biochips to screen for genomic imbalances. Genes Chromosomes Cancer. 1997; 20: 399-407.

70 - Pinkel D, et al. High resolution analysis of DNA copy number variation using comparative genomic hybridization to microarrays. Nat Genet. 1998; 20: 207-211.

71 - Snijders AM, et al. Assembly of microarrays for genome-wide measurement of DNA copy number. Nat Genet. 2001; 29: 263-264.

72 - Hodgson G, et al. Genome scanning with array CGH delineates regional alterations in mouse islet carcinomas. Nat Genet. 2001; 29: 459-464.

73 - Fiegler $\mathrm{H}$, et al. DNA microarrays for comparative genomic hybridization based on DOP-PCR amplification of BAC and PAC clones. Genes Chromosomes Cancer. 2003; 36:361-374.

74 - Smirnov DA, Burdick JT, Morley M \& Cheung VG. Method for manufacturing whole-genome microarrays by rolling circle amplification. Genes Chromosomes Cancer. 2004; 40:72-7.

75 - Ishkanian AS, et al. A tiling resolution DNA microarray with complete coverage of the human genome. Nat Genet. 2004; 36: 299-303.

76 - Theisen A. Microarray-based comparative genomic hybridization (aCGH). Nature Education. 2008; 1(1):45.

77 - Pollack JR, et al. Genome-wide analysis of DNA copy-number changes using cDNA microarrays. Nat Genet. 1999; 23: 41-6.

78 - Mantripragada KK, et al. DNA copy-number analysis of the 22q11 deletionsyndrome region using array-CGH with genomic and PCR-based targets. Int $J$ Mol Med. 2004; 13: 273-279.

79 - Brennan C, et al. High-resolution global profiling of genomic alterations with long oligonucleotide microarray. Cancer Res. 2004; 64: 4744-4748.

80 - Carvalho B, Ouwerkerk E, Meijer GA, \& Ylstra B. High resolution microarray comparative genomic hybridisation analysis using spotted oligonucleotides. J Clin Pathol. 2004; 57:644-6.

81 - Veltman JA. Genomic microarrays in clinical diagnosis. Curr Opin Pediatr. 2006; 18: 598-603.

82 - Le Scouarnec S, Gribble SM. Characterising chromosome rearrangements: Recent technical advances in molecular cytogenetics. Heredity. 2012; 108:7585. 
83 - Vasson A, et al. Custom oligonucleotide array-based CGH: a reliable diagnostic tool for detection of exonic copy number changes in multiple targeted genes. Eur J Hum Genet. 2013; 21(9):977-87.

84 - Hastings PJ, Lupski JR, Rosenberg SM, Ira G. Mechanisms of change in gene copy number. Nat Rev Genet. 2009; 10(8):551-64.

85 - Wain LV, Armour JA, Tobin MD. Genomic copy number variation, human health, and disease. Lancet. 2009; 374(9686):340-50.

86 - Emanuel BS, Saitta SC. From microscopes to microarrays: dissecting recurrent chromosomal rearrangements. Nat Rev Genet. 2007; 8(11):869-83.

87 - Shaffer LG, Theisen A, Bejjani BA, Ballif BC, Aylsworth AS, Lim C, McDonald M, et al.The discovery of microdeletion syndromes in the post-genomic era: review of the methodology and characterization of a new 1q41q42 microdeletion syndrome. Genet Med. 2007; 9(9):607-16.

88 - Potocki L, Bi W, Treadwell-Deering D, Carvalho CM, Eifert A, Friedman EM, et al. Characterization of Potocki-Lupski syndrome (dup(17)(p11.2p11.2)) and delineation of a dosage-sensitive critical interval that can convey an autism phenotype. Am J Hum Genet. 2007; 80(4):633-49.

89 - Bacolod MD, Schemmann GS, Giardina SF, Paty P, Notterman DA, Barany F. Emerging paradigms in cancer genetics: some important findings from highdensity single nucleotide polymorphism array studies. Cancer Res. 2009; 69: 723-7.

90 - de Leeuw N, Dijkhuizen T, Hehir-Kwa JY, Carter NP, Feuk L, Firth HV, et al. Diagnostic interpretation of array data using public databases and internet sources. Hum Mutat. 2012; 33(6):453-6.

91 - Bernardini L, Alesi V, Loddo S, Novelli A, Bottillo I, Battaglia A, et al. Highresolution SNP arrays in mental retardation diagnostics: how much do we gain? Eur J Hum Genet. 2010;18: 178-185.

92 - lafrate AJ, Feuk L, Rivera MN, Listewnik ML, Donahoe PK, Qi Y, Scherer SW, Lee C. Detection of large-scale variation in the human genome. Nat Genet 2004; 36: $949-951$.

93 - Redon R, Ishikawa S, Fitch KR, Feuk L, Perry GH, Andrews TD, et al. Global variation in copy number in the human genome. Nature. 2006; 444: 444-454.

94 - Gijsbers AC, Lew JY, Bosch CA, Schuurs-Hoeijmakers JH, van Haeringen A, den Hollander NS, et al. A new diagnostic workflow for patients with mental retardation and/or multiple congenital abnormalities: test arrays first. Eur J Hum Genet. 2009; 17:1394-1402.

95 - Wang J, Pang GS, Chong SS, Lee CG. SNP web resources and their potential applications in personalized medicine. Curr Drug Metab. 2012; 13:978-990. 
96 - Stankiewicz P, Beaudet AL. Use of array $\mathrm{CGH}$ in the evaluation of dysmorphology, malformations, developmental delay, and idiopathic mental retardation. Curr Opin Genet Dev. 2007;17:182-192.

97 - Alkan C, Coe BP, Eichler EE. Genome structural variation Discovery and genotyping. Nat Rev Genet. 2011;12:363-376.

98 - Koolen DA, Pfundt R, de Leeuw N, Hehir-Kwa JY, Nillesen WM, Neefs I, et al. Genomic microarrays in mental retardation: a practical workflow for diagnostic applications. Hum Mutat. 2009; 30: 283-292.

99 - Park SJ, Jung EH, Ryu RS, Kang HW, Ko JM, Kim HJ, et al. Clinical implementation of whole-genome array CGH as a first-tier test in 5080 pre and postnatal cases. Mol Cytogenet. 2011; 4:12.

100 - Kearney HM, South ST, Wolff DJ, Lamb A, Hamosh A, Rao KW. American College of Medical Genetics recommendations for the design and performance expectations for clinical genomic copy number microarrays intended for use in the postnatal setting for detection of constitutional abnormalities. Genet Med. 2011;13(7):676-9.

101 - Wincent J, Anderlid BM, Lagerberg M, Nordenskjold M, Schoumans J. Highresolution molecular karyotyping in patients with developmental delay and/or multiple congenital anomalies in a clinical setting. Clin Genet. 2011. 79: 147-157.

102 - Battaglia A, Doccini V, Bernardini L, et al. Confirmation of chromosomal microarray as a first-tier clinical diagnostic test for individuals with developmental delay, intellectual disability, autism spectrum disorders and dysmorphic features. Eur J Paediatr Neurol. 2013;17(6):589-99.

103 - South ST, Lee C, Lamb AN et al. ACMG Standards and Guidelines for constitutional cytogenomic microarray analysis, including postnatal and prenatal applications: revision 2013. Genet Med. 2013; 1(11):901-9.

104 - de Vries BB, Pfundt R, Leisink M, Koolen DA, Vissers LE, Janssen IM, et al. Diagnostic genome profiling in mental retardation. Am J Hum Genet. 2005; 77(4):606-616.

105 - Rosenberg C, Knijnenburg J, Bakker E, Vianna-Morgante AM, Sloos W, Otto $\mathrm{PA}$, et al. Array-CGH detection of micro rearrangements in mentally retarded individuals: clinical significance of imbalances present both in affected children and normal parents. J Med Genet. 2006;43(2):180-6.

106 - Siggberg L, Ala-Mello S, Jaakkola E, Kuusinen E, Schuit R, Kohlhase J, et al. Array CGH in molecular diagnosis of mental retardation - A study of 150 Finnish patients. Am J Med Genet A. 2010; 152 (6):1398-1410.

107 - Bartnik M, et al. The usefulness of array comparative genomic hybridization in clinical diagnostics of intellectual disability in children. Dev Period Med. 2014;18(3):307-17. 
108 - Hillman SC, et al. Additional information from array comparative genomic hybridization technology over conventional karyotyping in prenatal diagnosis: a systematic review and meta-analysis. Ultrasound Obstet Gynecol. 2011; 37(1):614.

109 - Krepischi-Santos AC, Vianna-Morgante AM, Jehee FS, Passos-Bueno MR, Knijnenburg J, Szuhai K, et al. Whole-genome array-CGH screening in undiagnosed syndromic patients: old syndromes revisited and new alterations. Cytogenet Genome Res. 2006; 115(3-4):254-61.

110 - Koolen DA, Sistermans EA, Nilessen W, Knight SJ, Regan R, Liu YT, et al. Identification of non-recurrent submicroscopic genome imbalances: the advantage of genome-wide microarrays over targeted approaches. Eur J Hum Genet. 2008. 16(3):395-400.

111 - Dorfman LM, Leite JCL, Giugliani R, Riegel M. Microarray-based comparative genomic hybridization analysis in neonates with congenital anomalies: detection of chromosomal imbalances. J Pediatria. 2015; 91(1): 59-67.

112 - Sebat J, Lakshmi B, Troge J, Alexander J, Young J, Lundin P, et al. Largescale copy number polymorphism in the human genome. Science. 2004; 305(5683):525-8.

113 - McCarroll SA, Hadnott TN, Perry GH, Sabeti PC, Zody MC, Barrett JC, et al. Common deletion polymorphisms in the human genome. Nat Genet. 2006; 38: 86-92.

114 - Stankiewicz P, e Lupski JR. Structural Variation in the Human Genome and its Role in Disease. Ann Rev Med. 2010; 61:437-455.

115 - Conrad DF, Pinto D, Redon R, Feuk L, Gokcumen O, Zhang Y, et al. Origins and functional impact of copy number variation in the human genome. Nature. 2010; 464(7289):704-12.

116 - Sharp AJ, Locke DP, McGrath SD, Cheng Z, Bailey JA, Vallente RU, et al. Segmental duplications and copy-number variation in the human genome. $A m \mathrm{~J}$ Hum Genet. 2005; 77:78-88.

117 - Locke DP, Sharp AJ, McCarroll SA, McGrath SD, Newman TL, Cheng Z, et al. Linkage disequilibrium and heritability of copy-number polymorphisms within duplicated regions of the human genome. Am J Hum Genet. 2006; 79:275-290.

118 - Khaja R, Zhang J, MacDonald JR, He Y, Joseph-George AM, Wei J, et al. Genome assembly comparison identifies structural variants in the human genome. Nat Genet. 2006; 38:1413-1418.

119 - Lupski JR. Genomic disorders: structural features of the genome can lead to DNA rearrangements and human disease traits. Trends Genet. 1998;14(10):41722.

120 - Lupski JR, Stankiewicz P. Genomic disorders: molecular mechanisms for rearrangements and conveyed phenotypes. PLoS Genet. 2005; 1(6):e49. 
121 - Sun Z, Liu P, Jia X, Withers MA, Jin L, Lupski JR, Zhang F. Replicative mechanisms of CNV formation preferentially occur as intrachromosomal events: evidence from Potocki-Lupski duplication syndrome. Hum Mol Genet. 2013; 22(4):749-56.

122 - Girirajan S, Rosenfeld JA, Coe BP, Parikh S, Friedman N, Goldstein A, et al. Phenotypic heterogeneity of genomic disorders and rare copy-number variants. $N$ Engl J Med. 2012;367(14):1321-31. Erratum in: N Engl J Med. 2012; 367(24):2362.

123 - Shoichet S, et al. Identification of candidate genes for sporadic amyotrophic lateral sclerosis by array comparative genomic hybridization. Amyotroph Lateral Scler, 10(3):162-9; 2009.

124 - Ferlini A, et al. Custom CGH array profiling of copy number variations (CNVs) on chromosome 6p21.32 (HLA locus) in patients with venous malformations associated with multiple sclerosis. BMC Medical Genetics. 2010; 11:64.

125 - Ensenauer RE, Adeyinka A, Flynn HC, Michels VV, Lindor NM, Dawson DB, et al. Microduplication 22q11.2, an emerging syndrome: clinical, cytogenetic, and molecular analysis of thirteen patients. Am J Hum Genet. 2003; 73: 1027-1040.

126 - Yobb TM, Somerville MJ, Willatt L, Firth HV, Harrison K, MacKenzie J, et al. Microduplication and triplication of 22q11.2: a highly variable syndrome. $A m \mathrm{~J}$ Hum Genet. 2005; 76: 865-876.

127 - Lee C, lafrate AJ, Brothman AR. Copy number variations and clinical cytogenetic diagnosis of constitutional disorders. Nat Genet. 2007; 39:S48-54.

128 - Kearney HM, Thorland EC, Brown KK, Quintero-Rivera F, South ST. American College of Medical Genetics standards and guidelines for interpretation and reporting of postnatal constitutional copy number variants. Genet Med. 2011; 13(7):680-5.

129 - Riggs ER, Church DM, Hanson K, et al: Towards an evidence-based process for the clinical interpretation of copy number variation. Clin Genet 2012; 81: 403412.

130 - Srebniak MI, Diderich KE, Govaerts LC, Joosten M, Riedijk S, Galjaard RJ, Van Opstal D.Types of array findings detectable in cytogenetic diagnosis: a proposal for a generic classification. Eur J Hum Genet. 2014;22(7):856-8.

131 - Vetro A, et al. The Introduction of Arrays in Prenatal Diagnosis: A Special Challenge. Hum Mutat, 2012; 33(6):923-9;.

132 - Gijsbers ACJ; Schoumans J; Ruivenkamp CAL. Interpretation of array Comparative Genome Hybridization data: a major challenge. Cytogenet Genome Res. 2011; 135(4-5):222-7.

133 - Shaikh TH, et al. High-resolution mapping and analysis of copy number variations in the human genome: A data resource for clinical and research applications. Genome Res. 2009; 19:1682-1690;. 
134 - Kriek M, White SJ, Szuhai K, Knijnenburg J, van Ommen GJ, den Dunnen JT, Breunin $\mathrm{MH}$. Copy number variation in regions flanked (or unflanked) by duplicons among patients with developmental delay and/or congenital malformations; detection of reciprocal and partial Williams-Beuren duplications. Eur J Hum Genet. 2006; 14:180-9.

135 - D'ambrosio $\mathrm{V}$, et al. Role of CGH array in the diagnosis of autosomal recessive disease: a case of Ellis-van Creveld syndrome. Prenat Diagn. 2015; 35(1):97-9.

136 - Bejjani BA; Shaffer LG. Clinical utility of contemporary molecular cytogenetics. Annu Rev Genomics Hum Genet. 2008; 9(1):71-86.

137 - MacDonald JR, Ziman R, Yuen RK, Feuk L, Scherer SW. The database of genomic variants: a curated collection of structural variation in the human genome. Nucleic Acids Res. 2014; 42(Database issue):D986-92..

138 - Firth HV, Richards SM, Bevan AP, Clayton S, Corpas M, Rajan D, et al. DECIPHER: database of chromosomal imbalance and phenotype in humans using ensembl resources. Am J Hum Genet. 2009; 84: 524-533.

139 - Cheung SW, et al. Microarray-based CGH detects chromosomal mosaicism not revealed by conventional cytogenetics. Am J Med Genet A. 2007; 143(1686):1679-1686.

140 - Schaaf CP, Wiszniewska J, Beaudet AL. Copy number and SNP arrays in clinical diagnostics. Annu Rev Genomics Hum Genet. 2011; 12:25-51.

141 - Riegel M. Human molecular cytogenetics: From cells to nucleotides. Genet Mol Biol. 2014; 37(1 Suppl):194-209.

142 - Gropman AL, Batshaw ML. Epigenetics, copy number variation, and other molecular mechanisms underlying neurodevelopmental disabilities: new insights and diagnostic approaches. J Dev Behav Pediatr. 2010; 31(7):582-91.

143 - Need AC, Shashi V, Hitomi Y, Schoch K, Shianna KV, McDonald MT, Meisler $\mathrm{MH}$, Goldstein DB. Clinical application of exome sequencing in undiagnosed genetic conditions. J Med Genet. 2012; 49(6):353-61.

144 - Schaaf CP, Sabo A, Sakai Y, Crosby J, Muzny D, Hawes A, Lewis L, Akbar H, Varghese R, Boerwinkle E, Gibbs RA, Zoghbi HY. Oligogenic heterozygosity in individuals with high-functioning autism spectrum disorders. Hum Mol Genet. 2011; 20(17):3366-75.

145 - Ellison JW, Rosenfeld JA, Shaffer LG. Genetic basis of intellectual disability. Annu Rev Med. 2013; 64:441-50.

146 - Pereira RR; Pinto IP; Minasi LB; de Melo AV; da Cruz e Cunha DM; Cruz AS; et al. Screening for intellectual disability using high-resolution CMA technology in a retrospective cohort from Central Brazil. PLoS One. 2014; 9(7): e103-117.

147 - Darilek S, et al. Pre and postnatal genetic testing by arraycomparative genomic hybridization: genetic counseling perspectives. Genet Med. 2008; 10(1):13-18. 
148 - Knight LA, Yong MH, Tan M, Ng IS. Del(3) (p25.3) without phenotypic effect. $J$ Med Genet. 1995; 32:994-995.

149 - Ben-Shachar S, Lanpher B, German JR, Potocki L, Sreenath Nagamani S, Franco LM, et al. Microdeletion 15q13.3: A locus with incomplete penetrance for autism, mental retardation, and psychiatric disorders. J Med Genet. 2009; 46:382-388.

150 - Wellcome Trust Case Control Consortium, Craddock N, Hurles ME, Cardin N, Pearson RD, Plagnol V, Robson S, et al. Genome-wide association study of CNVs in 16,000 cases of eight common diseases and 3,000 shared controls. Nature. 2010; 464(7289):713-20.

151 - Sajan SA, Fernandez L, Nieh SE, Rider E, Bukshpun P, Wakahiro M, et al. Both rare and de novo copy number variants are prevalent in agenesis of the corpus callosum but not in cerebellar hypoplasia or polymicrogyria. PLoS Genet. 2013; 9(10):e1003823.

152 - Edger, PP; Pires, CJ. Gene and genome duplications: the impact of dosagesensitivity on the fate of nuclear genes. Chromosome Res. 2009; 17(5):699-717.

153 - Boland E, Clayton-Smith J, Woo VG, McKee S, Manson FD, Medne L, et al. Mapping of deletion and translocation breakpoints in 1q44 implicates the serine/threonine kinase AKT3 in postnatal microcephaly and agenesis of the corpus callosum. Am J Hum Genet. 2007; 81(2):292-303.

154 - Hill AD, Chang BS, Hill RS, Garraway LA, Bodell A, Sellers WR, et al. A 2-Mb critical region implicated in the microcephaly associated with terminal 1q deletion syndrome. Am J Med Genet A. 2007; 143A:1692-8.

155 - Mazzeu JF, Vianna-Morgante AM, Krepischi AC, Oudakker A, Rosenberg C, Szuhai K, McGill J, Maccraughan J, van Bokhoven H, Brunner HG. Deletions encompassing 1q41q42.1 and clinical features of autosomal dominant Robinow syndrome. Clin Genet. 2010; 77(4):404-7.

156 - Malan V, Rajan D, Thomas S, Shaw AC, Louis Dit Picard H, Layet V, et al. Distinct effects of allelic NFIX mutations on nonsense-mediated mRNA decay engender either a Sotos-like or a Marshall-Smith syndrome. Am J Hum Genet. 2010; 87:189-98.

157 - Perlman SJ, Kulkarni S, Manwaring L, Shinawi M. Haploinsufficiency of ZNF238 is associated with corpus callosum abnormalities in $1 \mathrm{q} 44$ deletions. Am J Med Genet A. 2013; 161:711-6.

158 - Filges I, Rothlisberger B, Boesch N, Weber P, Wenzel F, Huber AR, et al. Interstitial deletion $1 \mathrm{q} 42$ in a patient with agenesis of corpus callosum: phenotype-genotype comparison to the 1q41q42 microdeletion suggests a contiguous 1q4 syndrome. Am J Med Genet A. 2010; 152A:987-93.

159 - Bruno DL, Anderlid BM, Lindstrand A, van Ravenswaaij-Arts C, Ganesamoorthy D, Lundin J, et al. Further molecular and clinical delineation of 
co-locating 17p13.3 microdeletions and microduplications that show distinctive phenotypes. J Med Genet. 2010; 47:299-311.

160 - Toyo-oka K, Shionoya A, Gambello MJ, Cardoso C, Leventer R, Ward HL, et al. 14-3-3epsilon is important for neuronal migration by binding to NUDEL: a molecular explanation for Miller-Dieker syndrome. Nat Genet. 2003; 34:274-85.

161 - Wilson BT, Harikumar C, Fisher RB. Agenesis of the corpus callosum in mosaic tetrasomy 8p. Clin Dysmorphol. 2010; 19:215-7.

162 - Battaglia A, Hoyme HE, Dallapiccola B, Zackai E, Hudgins L, McDonaldMcGinn D, et al. Further delineation of deletion 1p36 syndrome in 60 patients: a recognizable phenotype and common cause of developmental delay and mental retardation. Pediatrics. 2008; 121:404-10.

163 - Redon R, Rio M, Gregory SG, Cooper RA, Fiegler H, Sanlaville D, et al. Tiling path resolution mapping of constitutional 1 p36 deletions by array-CGH: contiguous gene deletion or "deletion with positional effect" syndrome? J Med Genet. 2005; 42:166-71.

164 - Rosenfeld JA, Crolla JA, Tomkins S, Bader P, Morrow B, Gorski J, et al. Refinement of causative genes in monosomy 1 p36 through clinical and molecular cytogenetic characterization of small interstitial deletions. Am J Med Genet $A$. 2010; 152A:1951-9.

165 - Giannikou K, Fryssira H, Oikonomakis V, Syrmou A, Kosma K, Tzetis M, et al. Further delineation of novel 1 p36 rearrangements by array-CGH analysis: narrowing the breakpoints and clarifying the "extended" phenotype. Gene. 2012; 506:360-8.

166 - Beaudet, AL. The Utility of Chromosomal Microarray Analysis in Developmental and Behavioral Pediatrics. Child Dev. 2013; 84(1):121-32.

167 - Downhill JE, Jr, Buchsbaum MS, Wei T, Spiegel-Cohen J, Hazlett EA, Haznedar MM, et al. Shape and size of the corpus callosum in schizophrenia and schizotypal personality disorder. Schizophr Res. 2000; 42:193-208.

168 - Osbun N, Li J, O'Driscoll MC, Strominger Z, Wakahiro M, Rider E, et al. Genetic and functional analyses identify DISC1 as a novel callosal agenesis candidate gene. Am J Med Genet A. 2011; 155A:1865-76.

169 - Mao Y, Ge X, Frank CL, Madison JM, Koehler AN, Doud MK, et al. Disrupted in schizophrenia 1 regulates neuronal progenitor proliferation via modulation of GSK3beta/beta-catenin signaling. Cell. 2009; 136:1017-31.

170 - Booth R, Wallace GL, Happé F. Connectivity and the corpus callosum in autism spectrum conditions: insights from comparison of autism and callosal agenesis. Prog Brain Res. 2011; 189:303-17.

171 - Paul LK, Corsello C, Kennedy DP, Adolphs R. Agenesis of the corpus callosum and autism: a comprehensive comparison. Brain. 2014; 137(Pt 6):1813-29. 
172 - Eichele H, Plessen, KJ. Neural Plasticity in Functional and Anatomical MRI Studies of Children with Tourette Syndrome. Behav Neurol. 2013; 27(1): 33-45.

173 - Dramsdahl M, Westerhausen R, Haavik J, Hugdahl K, Plessen KJ. Adults with attention-deficit/hyperactivity disorder - a diffusion-tensor imaging study of the corpus callosum. Psychiatry Res. 2012; 201(2):168-73.

174 - Sisodiya SM, Free SL, Williamson KA, Mitchell TN, Willis C, Stevens JM, Kendall BE, Shorvon SD, Hanson IM, Moore AT, van Heyningen V. PAX6 haploinsufficiency causes cerebral malformation and olfactory dysfunction in humans. Nat Genet. 2001; 28:214-6.

175 - Free SL, Mitchell TN, Williamson KA, Churchill AJ, Shorvon SD, Moore AT, van Heyningen V, Sisodiya SM. Quantitative MR image analysis in subjects with defects in the PAX6 gene. Neuroimage. 2003; 20:2281-90.

176 - Ellison-Wright Z, Heyman I, Frampton I, Rubia K, Chitnis X, Ellison-Wright I, Williams SC, Suckling J, Simmons A, Bullmore E. Heterozygous PAX6 mutation, adult brain structure and fronto-striato-thalamic function in a human family. Eur $\mathrm{J}$ Neurosci. 2004; 19:1505-12.

177 - Bamiou DE, Free SL, Sisodiya SM, Chong WK, Musiek F, Williamson KA, van Heyningen V, Moore AT, Gadian D, Luxon LM. Auditory interhemispheric transfer deficits, hearing difficulties, and brain magnetic resonance imaging abnormalities in children with congenital aniridia due to PAX6 mutations. Arch Pediatr Adolesc Med. 2007; 161:463-9.

178 - Abouzeid $\mathrm{H}$. et al. PAX6 aniridia and interhemispheric brain anomalies. Mol Vis. 2009; 15: 2074-2083.

179 - Kelberman D, Rizzoti K, Avilion A, Bitner-Glindzicz M, Cianfarani S, Collins J, et al. Mutations within Sox2/SOX2 are associated with abnormalities in the hypothalamo-pituitary-gonadal axis in mice and humans. J Clin Invest. 2006; 116:2442-55.

180 - Rackley, RR, Flenniken, AM, Kuriyan, NP, Kessler, PM, Stoler, MH, Williams, BR Expression of the Wilms' tumor suppressor gene WT1 during mouse embryogenesis. Cell Growth Differ. 1993; 4: 1023-1031.

181 - Dennis SL, Manji SSM, Carrington DP, Scarcella DL, Ashley DM, Smith PJ, Algar EM. Expression and mutation analysis of the Wilms' tumor 1 gene in human neural tumors. Int J Cancer. 2002; 97 (5): 713-5.

182 - Rong $\mathrm{Y}$, Cheng $\mathrm{L}$, Ning $\mathrm{H}$, et al. Wilms' tumor 1 and signal transducers and activators of transcription 3 synergistically promote cell proliferation: a possible mechanism in sporadic Wilms' tumor. Cancer Res. 2006; 66:8049-57.

183 - Sugiyama H. WT1 (Wilms' tumor gene 1): biology and cancer immunotherapy. Jpn J Clin Oncol. 2010; 40:377-87.

184 - Wagner K-D, Wagner N, Schedl A. The complex life of WT1. J Cell Sci. 2003; 116:1653-1658. 
185 - Hohenstein P; Hastie ND. The many facets of the Wilms' tumour gene, WT1. Hum Mol Genet. 2006; 15 (2): R196-R201.

186 - Jinno Y, Yun K, Nishiwaki K, Kubota T, Ogawa O, Reeve AE, Niikawa N. Mosaic and polymorphic imprinting of the WT1 gene in humans. Nat Genet. 1994; 6(3):305-9.

187 - Wagner N, Wagner KD, Schley G, Coupland SE, Heimann H, et al. The Wilms' tumor suppressor WT1 is as- sociated with the differentiation of retinoblastoma cells. Cell Growth Differ. 2002;13:297-305.

188 - Wagner N, Wagner KD, Hammes A, Kirschner KM, Vidal VP, et al. A splice variant of the Wilms' tumour suppressor Wt1 is required for normal development of the olfactory system. Development. 2005; 132(6):1327-36.

189 - Kulahin N, Walmod PS. WITHDRAWN: The Neural Cell Adhesion Molecule NCAM2/OCAM/RNCAM, a Close Relative to NCAM. Adv Exp Med Biol. 2010; 663:403-20.

190 - Winther M, Berezin V, Walmod PS. NCAM2/OCAM/RNCAM: cell adhesion molecule with a role in neuronal compartmentalization. Int $J$ Biochem Cell Biol. 2012; 44(3):441-6.

191 - Walz A., Mombaerts P., Greer C.A.; Treloar H.B. Disrupted compartmental organization of axons and dendrites within olfactory glomeruli of mice deficient in the olfactory cell adhesion molecule. OCAM. Mol Cell Neurosci. 2006; 32:1-14.

192 - Makino T, McLysaght A. Ohnologs in the human genome are dosage balanced and frequently associated with disease. Proc Natl Acad Sci. 2010;107: 92709274.

193 - Hussman JP, Chung RH, Griswold AJ, Jaworski JM, Salyakina D, Ma D, et al. A noise-reduction GWAS analysis implicates altered regulation of neurite outgrowth and guidance in autism. Mol Autism. 2011;2(1):1.

194 - Han M-R, Schellenberg G, Wang L-S. Alzheimer's Disease Neuroimaging Initiative Genome-wide association reveals genetic effects on human Abeta42 and tau protein levels in cerebrospinal fluids: a case control study. BMC Neurol. 2010; 10:90.

195 - Petit F, Plessis G, Decamp M, Cuisset JM, Blyth M, Pendlebury M, Andrieux. 21q21 deletion involving NCAM2: report of 3 cases with neurodevelopmental disorders. J Eur J Med Genet. 2015; 58(1):44-6.

196 - Andersen EF, Carey JC, Earl DL, Corzo D, Suttie M, Hammond P, South ST. Deletions involving genes WHSC1 and LETM1 may be necessary, but are not sufficient to cause Wolf-Hirschhorn Syndrome. Eur J Hum Genet. 2014; 22(4):464-70.

197 - Kim JY, Kee HJ, Choe NW, et al. Multiple-myeloma-related WHSC1/MMSET isoform RE-IIBP is a histone methyltransferase with transcriptional repression activity. Mol Cell Biol. 2008; 28:2023-2034. 
198 - Greer EL, Shi Y. Histone methylation: a dynamic mark in health, disease and inheritance. Nat Rev Genet. 2012; 13:343-357.

199 - Nimura K, Ura K, Shiratori H, et al. A histone H3 lysine 36 trimethyltransferase links Nkx2-5 to Wolf-Hirschhorn syndrome. Nature. 2009; 460:287-291.

200 - Battaglia A, Filippi T, Carey JC. Update on the clinical features and natural history of Wolf-Hirschhorn (4p-) syndrome: experience with 87 patients and recommendations for routine health supervision. Am J Med Genet Part C Semin Med Genet. 2008; 148C:246-51.

201 - Zollino M, Murdolo M, Marangi G, Pecile V, Galasso C, Mazzanti L, Neri G: On the nosology and pathogenesis of Wolf-Hirschhorn syndrome: genotypephenotype correlation analysis of 80 patients and literature review. Am J Med Genet C Semin Med Genet. 2008;148C:257-269.

202 - Battaglia A, Carey JC. Update on the clinical features and natural history of Wolf Hirschhorn syndrome (WHS): experience with 48 cases. Am J Hum Genet. 2000; 67:127.

203 - Smith, K. et al. Midline radial glia translocation and corpus callosum formation require FGF signaling. Nature Neurosci. 2006; 9:787-797.

204 - Shu T, Sundaresan V, McCarthy MM, Richards LJ. Slit2 guides both precrossing and postcrossing callosal axons at the midline in vivo. J Neurosci. 2003; 23: 8176-8184.

205 - Reichenbach H, Holland H, Dalitz E, Demandt C, Meiner A, Chudobal, Lemke J, Claussen U, Froster UG. De novo completetrisomy 5p: clinical report and FISH studies. Am J Med Genet. 1999; 85:447-451.

206 - Grosso S, Cioni M, Garibaldi G, Pucci L, Galluzzi P, Canapicchi R, Morgese G e Balestri $P$. De novo complete trisomy $5 \mathrm{p}$ : Clinical and neuroradiological findings. Am J Med Genet. 2002; 112: 56-60.

207 - Higgins JJ, Pucilowska J, Lombardi RQ, Rooney JP. A mutation in a novel ATP-dependent Lon protease gene in a kindred with mild mental retardation. Neurology. 2004; 63(10):1927-31.

208 - Grozeva D, Carss K, Spasic-Boskovic O, Parker MJ, Archer H, Firth HV, Park SM, Canham N, Holder SE, Wilson M, Hackett A, Field M, Floyd JA; UK10K Consortium, Hurles M, Raymond FL. De novo loss-of-function mutations in SETD5, encoding a methyltransferase in a 3p25 microdeletion syndrome critical region, cause intellectual disability. Am J Hum Genet. 2014; 94(4):618-24.

209 - Rubert, G. Ethanol exposure during embryogenesis decreases the radial glial progenitor pool and affects the generation of neurons and astrocytes. J Neurosci Res. 2006; 84: 483-496.

210 - Evrard SG. Altered neuron-glia interactions in a low, chronic prenatal ethanol exposure. Brain Res Dev Brain Res. 2003; 147:119-133. 
211 - Guerri C, Pascual M, Renau-Plqueras J. Glia and fetal alcohol syndrome. Neurotoxicology. 2001; 22: 593-599.

212 - Graham V, Khudyakov J, Ellis P, Pevny L. SOX2 functions to maintain neural progenitor identity. Neuron. 2003; 39:749-65.

213 - Cohen MM. Holoprosencephaly: Clinical, anatomic, and molecular dimensions. Birth Defects Res A Clin Mol Teratol. 2006; 76(9):658-73.

214 - Chabchoub E, Willekens D, Vermeesch J, Fryns J-P. Holoprosencephaly and ZIC2 microdeletions: novel clinical and epidemiological specificities delineated. Clin Genet. 2012; 81: 584-589.

215 - Brown S, Russo J, Chitayat D, Warburton D. The 13q- syndrome: the molecular definition of a critical deletion region in band 13q32. Am J Hum Genet. 1995; $57: 859-866$.

216 - Kirchhoff M, Bisgaard AM, Stoeva R, Dimitrov B, Gillessen-Kaesbach G, Fryns $\mathrm{JP}$, et al. Phenotype and 244k array-CGH characterization of chromosome 13q deletions: an update of the phenotypic map of 13q21.1-qter. Am J Med Genet $A$. 2009; 149A: 894-905.

217 - Huang C, Yang YF, Yin N, Chen JL, Wang J, Zhang H, et al. Congenital heart defect and mental retardation in a patient with a 13q33.1-34 deletion. Gene. 2012; 498:308-310.

218 - Lalani SR, Shaw C, Wang X, Patel A, Patterson LW, Kolodziejska K, et al. Rare DNA copy number variants in cardiovascular malformations with extracardiac abnormalities. Eur J Hum Genet. 2013; 21:173-181.

219 - Vulto-van Silfhout AT, Hehir-Kwa JY, van Bon BW, Schuurs-Hoeijmakers JH, Meader S, Hellebrekers CJ, et al. Clinical significance of de novo and inherited copy-number variation. Hum Mutat. 2013; 34(12):1679-87.

220 - Hehir-Kwa JY, et al. De novo copy number variants associated with intellectual disability have a paternal origin and age bias. J Med Genet. 2011; 48:776-8.

221 - Wimplinger I, Shaw GM, Kutsche K. HCCS loss-of-function missense mutation in a female with bilateral microphthalmia and sclerocornea: a novel gene for severe ocular malformations? Mol Vis. 2007; 13:1475-1482.

222 - Vergult S, Leroy B, Claerhout I, Menten B. Familial cases of a submicroscopic Xp22.2 deletion: genotype-phenotype correlation in microphthalmia with linear skin defects syndrome. Mol Vis. 2013; 19:311-318.

223 - Wimplinger I, Rauch A, Orth U, Schwarzer U, Trautmann U, Kutsche K. Mother and daughter with a terminal Xp deletion: implication of chromosomal mosaicism and X-inactivation in the high clinical variability of the microphthalmia with linear skin defects (MLS) syndrome. Eur J Med Genet. 2007; 50:421-431. 
224 - Conti V, Carabalona A, Pallesi-Pocachard E, Parrini E, Leventer RJ, Buhler E, et al. Periventricular heterotopia in $6 q$ terminal deletion syndrome: role of the C6orf70 gene. Brain. 2013; 136(Pt 11):3378-94.

225 - Peddibhotla S, Nagamani SC, Erez A, Hunter JV, Holder JL Jr, Carlin ME, et al. Delineation of candidate genes responsible for structural brain abnormalities in patients with terminal deletions of chromosome 6q27. Eur J Hum Genet. 2015; 23(1):54-60.

226 - Chen B, Wang JF, Sun X, Young LT. Regulation of GAP-43 expression by chronic desipramine treatment in rat cultured hippocampal cells. Biol Psychiatry. 2003; 53(6):530-7.

227 - Baranek C, Dittrich M, Parthasarathy S, Bonnon CG, Britanova O, Lanshakov $D$, et al. Protooncogene Ski cooperates with the chromatin-remodeling factor Satb2 in specifying callosal neurons. Proc Natl Acad Sci USA. 2012; 109:354651.

228 - Zhao J, Matthies DS, Botzolakis EJ, Macdonald RL, Blakely RD, Hedera P. Hereditary spastic paraplegia-associated mutations in the NIPA1 gene and its Caenorhabditis elegans homolog trigger neural degeneration in vitro and in vivo through a gain-of-function mechanism. Clin Genet. 2007; 72: 271-287.

229 - Cooper GM, Coe BP, Girirajan S., Rosenfeld, J.A., Vu, T.H., Baker, C.,Cronin, $S$.; et al. Analysis of genome-wide copy number variation in Irish and Dutch ALS populations. Hum Mol Genet,17(21):3392-8; 2008.

230 - Sprecher E, et al. A mutation in SNAP29, coding for a SNARE protein involved in intracellular trafficking, causes a novel neurocutaneous syndrome characterized by cerebral dysgenesis, neuropathy, ichthyosis, and palmoplantar keratoderma. Am J Hum Genet. 2005; 77:242-251.

231 - Chen EH, Olson EN. Unveiling the mechanisms of cell-cell fusion. Science. 2005; 308(5720):369-73.

232 - Su Q, Mochida S, Tian JH, Mehta R, Shen ZH. SNAP-29: a general SNARE protein that inhibits SNARE disassembly and is implicated in synaptic transmission. Proc Natl Acad Sci USA. 2001; 98:14038-14043.

233 - Park TJ, Curran T. Crk and Crk-like play essential overlapping roles downstream of disabled-1 in the Reelin pathway. $J$ Neurosci. 2008; 28:1355113562.

234 - Buysse K, Delle Chiaie B, Van Coster R, Loeys B, De Paepe A, et al. Challenges for CNV interpretation in clinical molecular karyotyping: lessons learned from a 1001 sample experience. Eur J Med Genet. 2009; 52: 398-403. 


\title{
ANEXO A - DOCUMENTO DE APROVAÇÃO DO COMITÊ DE ÉTICA E PESQUISA - UNB
}

\author{
4 \\ UNIVERSIDADE DE BRASÍLIA \\ FACULDADE DE MEDICINA \\ Comitê de Ética em Pesquisa em Seres Humanos
}

ANÁLISE DE PROJETO DE PESQUISA

Registro de Projeto: CEP-FM 081/2009.

Título: "Investigação da etiologia do retardo mental sindrômico".

Pesquisador Responsável: Iris Ferrari.

Documentos analisados: Folha de rosto, carta de encaminhamento, declaração de responsabilidade, protocolo de pesquisa, termo de consentimento livre e esclarecido, cronograma, bibliografia pertinente e currículo (s) de pesquisador (es).

Data de entrega: 13/10/2009.

Proposição do (a) relato (a)

(X) Aprovação

( ) Não aprovação.

Data da primeira análise pelo CEP-FM/UNB: 28/10/2009.

Data do parecer final do projeto pelo CEP-FM/UNB: 25/11/2009.

\section{PARECER}

Com base na Resolução CNS/MS no 196/96 e resoluções posteriores, que regulamentam a matéria, o Comitê de Ética em Pesquisa da Faculdade de Medicina da Universidade de Brasília decidiu APROVAR "ad referendum", conforme parecer do (a) relator (a) o projeto de pesquisa acima especificado, quanto aos seus aspectos éticos.

1. Modificações no protocolo devem ser submetidas ao CEP, assim como a notificação imediata de eventos adversos graves;

2. $\mathrm{O}(\mathrm{s})$ pesquisador (es) deve (m) apresentar relatórios periódicos do andamento da pesquisa ao CEP-FM.

Brasília, 26 de Novembro de 2009.

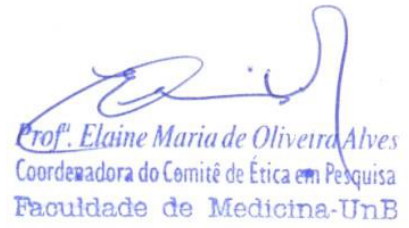




\section{ANEXO B - TERMO DE CONSENTIMENTO LIVRE E ESCLARECIDO (TCLE)}

A pesquisa intitulada "Investigação da etiologia do retardo mental sindrômico" pretende investigar a relação entre as alterações cromossômicas e o quadro clínico dos portadores.

Você está sendo convidado (a) a participar do projeto acima citado. O presente convite contém informações sobre a pesquisa que estamos fazendo. Sua colaboração neste estudo será de grande importância. Para a realização da pesquisa será necessária a retirada de 4 a $8 \mathrm{~mL}$ de sangue de uma das veias do antebraço do paciente e seus genitores para exame feito rotineiramente no laboratório. Este procedimento de coleta de sangue será realizado por pessoa qualificada, é de risco mínimo para a saúde podendo, entretanto, provocar pequeno desconforto. Resultando o teste positivo, será garantido um relatório explicativo sobre esta condição.

A Professora Doutora Íris Ferrari é a pesquisadora responsável pelos procedimentos envolvidos, bem como da utilização dos dados produzidos durante a realização desta pesquisa. A identidade do paciente será mantida em segredo absoluto no caso de qualquer forma de divulgação desta pesquisa.

A recusa em participar da presente pesquisa não resultará em qualquer prejuízo presente ou futuro na prestação de assistência profissional pela equipe do Serviço de Genética Clínica do HUB, ficando também ressaltado que, mesmo após a assinatura do presente termo de consentimento, poderá abandonar a pesquisa a qualquer momento.

Os exames e coleta de sangue para análise só serão realizados se houver concordância em participar deste estudo. Para tal, pedimos gentilmente que o paciente ou seu responsável assine o presente documento que será entregue em duas vias, uma para o paciente e outra que será mantida no Laboratório de Genética Clínica da Faculdade de Medicina - UNB. Participando desta pesquisa, estará ajudando no diagnóstico, aconselhamento genético e melhor entendimento das causas do retardo mental.

$\mathrm{Eu}$, ,profissão

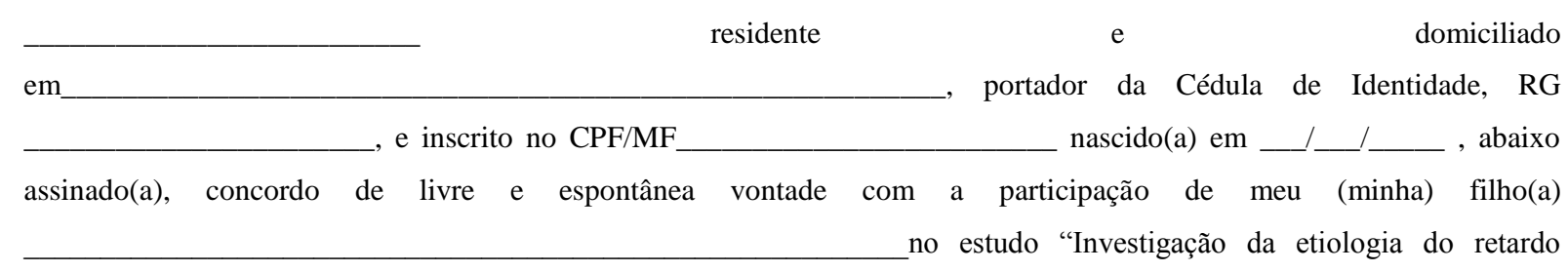

mental sindrômico", e afirmo que obtive todas as informações que considero necessárias.

Caso tenham sido tiradas fotografias:

( ) Concordo que sejam incluídas em publicações científicas, se necessário.

( ) Concordo que sejam apresentadas em aulas para profissionais da saúde.

( ) Não concordo que sejam incluídas em qualquer tipo de publicação ou apresentação.

Brasília, de de 20

Assinatura do participante

Dra. Íris Ferrari

Pesquisadora responsável

Telefone para contato: (61) 33072505 